\title{
THE INFLUENCE OF JOACHIM IN THE 13TH CENTURY
}

\author{
Frances Andrews
}

The end of the 12th century was one of the periods of great eschatological potential in the medieval Latin west. In October 1187 Jerusalem was lost to a Kurdish sultan, Saladin, and the Crusade campaigns which followed were catastrophic. Tensions between the English and French crowns were at a peak, and in June 1190 the western Emperor, Frederick I Barbarossa, drowned in the river Göksu (Saleph) on his way to the Holy Land. Things were no better in the Iberian peninsula: in July 1195 the Almohad Muslim prince Ya 'qub I al-Mansur (the victorious) defeated the Christian King Alfonso VIII of Castille at the Battle of Alarcos.

It was against this unstable background that Joachim, in the preface to his Liber de Concordia, wrote of his self-chosen role in preparing the Church in the face of the enemy: ${ }^{1}$

Our [task] is to foresee wars, yours is to hasten to arms. It is for us to go up to the watchtower on the mountain and, having seen the enemy, to give warning; yours, having heard the signal, is to take refuge in safer places. We, although unworthy scouts, witnessed long ago that the said wars would come. Would that you were worthy soldiers of Christ! "Let

\footnotetext{
${ }^{1}$ For a chronology of his works as then known, see Kurt-Victor Selge, "L'origine delle opere di Gioacchino da Fiore," in L'attesa della fine dei tempi nel medioevo, eds. Ovidio Capitani and Jürgen Miethke (Annali dell'Istituto storico italo-germanico Quaderno, 28) (Bologna, 1990), pp. 87-131. Since Selge wrote, the dating he proposes for the "De vita Benedicti" has been queried by Felice Accrocca, "Intorno ad alcuni recenti studi gioachimiti," Rivista di Storia della Chiesa in Italia 51 (1997), 149-174. Robert E. Lerner, "Ecstatic Dissent," Speculum 67 (1992), 33-57; p. 39 note 27 also assigns it a revised date. Most recently Alexander Patschovsky argues that Part 1 was written between 1184 and 1187/8, Parts 2 and 3 between Easter 1187 and Easter 1188, and Part 4 slightly after Easter 1188. See Tractatus in expositionem vite et regule beati Benedicti, in Ioachim abbas Florensis Opera Omnia 4: Opera Minora 4, ed. Alexander Patschovsky (Fonti per la storia dell'Italia medieval: Antiquitates 29) (Rome, 2008).
} 
us throw off the deeds of darkness and take up the arms of light" [Romans 13:12]. ${ }^{2}$

In this, as in many of his other works, Joachim was voicing a widely shared dissatisfaction with the current state of the world and of the Church in particular, but his words resonated more deeply than any contemporary reform treatise. Marjorie Reeves, who spent a long life studying Joachim's influence, summed it up with convenient economy. He was to be renowned as:

the prophet of the Antichrist, the interpreter of the seven-headed dragon, the oracle on the fate of Jerusalem, the recipient of a miraculous gift ofspiritual understanding, the prophet of the two great mendicant orders, and the proclaimer of 1260 as the year of crisis. ${ }^{3}$

Of these, the last, at least, would have surprised him: Joachim himself was careful never to specify a date.

\section{Preliminaries}

The purpose of what follows is to outline the main features of perceptions of Joachim in the 13th century and the mechanisms and extent of the reception of his ideas. This chapter will also sketch something of the way historians in the 20th and 21st centuries have portrayed him. But tracking the influence of a medieval thinker is never straightforward, particularly when so much may be explained by reference to a common biblical hinterground. ${ }^{4}$ Nor does the nature of prophecy simplify matters. Augustine had opposed speculation about the end of time and Augustinian theologians taught that the gift of prophecy, communicating direct divine revelation about the course of salvation, had become unnecessary after the time of the primitive Church. The Dominican theologian Albertus Magnus (d. 1280) was to argue that prophecy required "people with an acute intellect and a well-ordered imagination, so that the intellect can work with clear intelligible species.” Real prophecy, as against divination in dreams and visions, was restricted to those "who shun bodily and worldly passions and devote themselves to a life of contemplation and study" thereby acquiring the ability to receive the divine gift of prophetic insight. ${ }^{5}$ Claiming the status of prophet was thus a hubristic activity. What is more, medieval prophecies had to be obscure to

\footnotetext{
${ }^{2}$ Abbot Joachim of Fiore. Liber de Concordia Noui ac Veteris Testamenti 1-4 ed. E. Randolph Daniel, (Transactions of the American Philosophical Society 73, Part 8) (Philadelphia, 1983), pp. i-455, prephatio pp. 10-11.

${ }^{3}$ Marjorie Reeves, “The Originality and Influence of Joachim of Fiore," Traditio 35 (1980), 269-316, 298. I have used Reeves' themes to frame some of the sections below.

${ }^{4}$ Bernard McGinn, Visions of the End. Apocalyptic Traditions in the Middle Ages (1979; repr. with a new preface and expanded bibliography, New York, 1998), p. 323 note 14. This volume includes convenient English translations of selected passages from key Joachite texts pp. 161-167, 172-179.

${ }^{5}$ Albertus Magnus, "De somno et vigilia," ed. A Borguet, Alberti Magni Opera Omnia 9 (Paris, 1890), pp. 121-212. Discussed in Bert Roest, "Divination, Visions and Prophecy according to Albert the Great," in Media Latinitas. A Collection of Essays to Mark the Occasion of the Retirement of L.J. Engels (Turnhout, 1996), pp. 323-328.
} 
match the obscurity of the biblical prophets, Daniel and John, or the Sibyls. It was a combination which encouraged anonymity, convolution and (in some authors, though not Joachim) ventriloquism. In the specific case of Joachim, it has been suggested that his importance lay in the very complexity of his thinking: "the multitude of possibilities he introduced for the structuring and comprehension of historical reality." Such qualities also encouraged the writing of explanatory commentaries which, in turn, served as convenient tools for the analysis of current affairs according to the views of the writer, and often involved the "post eventum" modification of a prophetic text to bring it up to date.

Aspects of Joachim's thinking had great creative potential, prompting the rapid development of pseudo-Joachite texts full of ideas which were (or could be) identified with Joachim, but which are not to be found in his works. But there was no fixed "text" and indeed, Joachim's own approach to his writings itself exemplifies the fluidity. Using a comparison, or concordance, of the two biblical Testaments, he explained the course of world history as seven ages (etates), with seven times (tempora) of the Church and three stages (status) of spiritual growth, culminating in that of the Holy Spirit. ${ }^{7}$ An essential element of Joachism was thus to be the expectation of a historical period of radical change in the life of the Church and of the world brought about by the Holy Spirit. ${ }^{8}$ The period after the defeat of the Antichrist and before the end of the world would be the earthly Sabbath, a time of peace--that is, the third status, the idea which was perhaps most responsible for his lasting influence in the history of ideas. ${ }^{9}$ But Joachim himself only gradually refined his thinking on these millenarian issues, silently changing his mind about some of the details, sometimes in the course of a single work, and not always achieving certainty. ${ }^{10} \mathrm{He}$ moved the location of the Antichrist, for example, from Babylon/Jerusalem to a false Christian born in Rome and destined to take the papal throne. Had Jerusalem remained the centre of the story, there can be little doubt that its loss--putting it outside Christian lands--would have reduced any urgency in the message for his contemporaries. ${ }^{11}$ The

\footnotetext{
${ }^{6}$ Bernard McGinn, "Influence and Importance in Evaluating Joachim of Fiore," in Il profetismo gioachimita tra Quattrocento e Cinquecento. Atti del III Congresso internazionale di Studi Gioachimiti (1721 September 1989), ed. Gian Luca Potestà (Opere di Gioacchino da Fiore: Strumenti, 3) (Genoa, 1991), pp. 14-36, p. 18.

7 David Burr notes that status is both a reference to time, so that "age" or "period" are acceptable translations, and to a qualitative position, better translated as "a state of being." David Burr, "Olivi's Apocalyptic Timetable," The Journal of Medieval and Renaissance Studies 11 (1981), 237-260, 237 note 3. ${ }^{8}$ See Gian Luca Potestà, Angelo Clareno dai poveri eremiti ai fraticelli (Nuovi studi storici, 8) (Rome, 1990), p. 13, with reference to the earlier scholarship of Grundmann, Töpfer, McGinn, and Lerner, for whose works, see the notes below.

${ }^{9}$ See Julia Eva Wannenmacher, 'Apocalypse, Antichrists and the Third Age. Joachim's Peaceful Revolution', in Ancient Christian Interpretations of 'Violent Texts' in the Apocalypse, ed. Joseph Verheyden, Tobias Nicklas and Andreas Merkt (Göttingen, 2011), pp. 267-286, p. 268.

${ }^{10}$ See for example, the brief discussion of the Liber de Concordia by Julia Eva Wannenmacher, "Die Macht des Bösen. Zur Rolle und Bedeutung des Antichristen in der Eschatologie Joachims von Fiore," Florensia 13/14 (1999-2000), 365-378, 371, or the differences between it and the De Septem Sigillis, ibid. p. 377. See also Eadem, 'Apocalypse, Antichrists and the Third Age', p. 274.

${ }^{11}$ Gian Luca Potestà, "Apocalittica e politica in Gioacchino da Fiore," in Endzeiten. Eschatologie in den monotheistischen Weltreligionen, eds. Wolfram Brandes and Felicitas Schmieder (Millennium-Studien zu
} 
change, instead, whether deliberately or not, precluded contradiction or indifference. It need, then, be no surprise that later writers made similar changes. Nor is it surprising that the first task undertaken by many post-Enlightenment scholars seeking to establish the extent of Joachim's influence has been to untangle where possible the reception of his own ideas, either from those which predated him, or from those later ascribed to him simply to lend authority to an interpretation of events or an identification of political enemies. ${ }^{12}$ It remains, however, a contentious business.

The fundamental work on the sources for Joachim's life was undertaken from the 1920s by a young German medievalist, Herbert Grundmann (1902-1970), whose findings have remained perennially important, persisting in the footnotes of most more recent research, including the essays in this volume. ${ }^{13}$ This is true of a scattering of other scholars whose work on the sources is still cited, but most mid-20th century conceptions of Joachim's influence, by writers inclined to underline his impact in broad terms, whether positive or negative, have since been set aside. These include the views of the Italian anti-fascist theologian, Ernesto Buonaiuti (1881-1946), an excommunicate priest and one of the first to explore Joachism, or the French nobleman and Jesuit theologian, Henri de Lubac (1896-1991), who, like the Austrian

Kultur und Geschichte des ersten Jahrtausends nach Christus, 16) (Berlin-New York, 2008), pp. 231248, pp. 233, 243; Idem, "Gli spazi dell'Anticristo," in Il secolo xii: la "renovatio" dell'Europa cristiana, eds. Giles Constable, Giorgio Cracco, Hagen Keller, and Diego Quaglioni (Bologna, 2003), pp. 393-421. ${ }^{12}$ In what follows the distinction between Joachite and Joachimist will usually follow McGinn: "Joachite in the sense that they are influenced by the body of ideas claiming Joachim at its source," and "Joachimist, that is, truly in harmony with the authentic writings and major ideas of the Abbot of Fiore." Bernard McGinn, "The Abbot and the Doctors: Scholastic Reactions to the Radical Eschatology of Joachim of Fiore," Church History 40 (1971), 30-47, 35. This is close to the German distinction between joachitisch and joachimisch, but contrasts with the terminology adopted by Troncarelli who (in part a product of the structure of Italian as against English) distinguishes between gioachimiti--Joachim's followers in the strict sense, in the spirit and often the letter, who scrupulously copied the teachings of the master, updating them slightly but otherwise leaving them untouched--and gioachimisti, that is, the followers faithful only to certain general convictions but who were ready creatively to re-work his message, with the concomitant risk that they misunderstood or substantially modified his ideas. Fabio Troncarelli, "Il Liber Figurarum tra 'gioachimiti' e 'gioachimisti,"” in Gioacchino da Fiore tra Bernardo di Clairvaux e Innocenzo III. Atti del $5^{\circ}$ Congresso internazionale di studi gioachimiti (16-21 September 1999), ed. Roberto Rusconi (Opere di Gioacchino da Fiore: testi e strumenti, 13) (Rome, 2001), pp. 267-281, p. 268. More recently Gian Luca Potestà has observed, rightly, that these terms understate the complexity of the issue ("“risolvono un po' troppo gordianamente un nodo ermeneutico in verità molto intricato"). See Potestà, "Il Super Hieremiam e il gioachimismo della dirigenza minoritica della metà del duecento," in Mediterraneo, Mezzogiorno, Europa, studi in onore di Cosimo Damiano Fonseca, eds. Giancarlo Andenna and Hubert Houben, 2 vols. (Bari, 2004), vol. 2, pp. 879-894, pp. 879-80. The boundaries between what is and what is not "Joachite" are often fluid, but the distinction remains useful for the purposes of this chapter.

${ }^{13}$ An Italian translation of Grundmann's key works was published as recently as the late 1990s: Herbert Grundmann, Gioacchino da Fiore. Vita e opere, ed. Gian Luca Potestà (Opere di Gioacchino da Fiore. Testi e Strumenti, 8) (Rome, 1997). The main German works were collected in Herbert Grundmann, Ausgewählte Aufsätze, Part 2: Joachim von Fiore (MGH Schriften, 25.2) (Stuttgart, 1977). See also below, notes 32, 39, 253 and 296. 
political philosopher Eric Vögelin (1901-1985) (an escapee during the Nazi era), saw Joachim as a destructive force, an anticlerical revolutionary, or even the dark prophet of the Third Reich. ${ }^{14}$ A key exception to this rule is the work of Marjorie Reeves (1905-2003), who began by looking at Joachim's reputation and influence in the 15th and 16th centuries and moved gradually earlier in her research, becoming the foremost advocate of Joachim's originality and effect. In 1969 she concluded that his work marked a "turning point in medieval thought about Last Things." His Trinitarian framework gave new force "to concepts of the Millennium and the Sabbath Age." 15 In the 1970s and 1980s these conclusions were contested by a number of authors, including Raoul Manselli and Robert Lerner, who re-examined the roots of Joachim's thinking. Manselli, a historian of popular religion, unsurprisingly deemed Reeves' approach to be too focused on intellectual ideas and detached from the religious needs of the people who produced them. ${ }^{16}$ Lerner instead argued that, although Joachim went "far beyond his sources," his originality on some issues had been exaggerated. ${ }^{17}$ He noted, for example, the contrast between traditional Augustinian pessimism about worldly life and the optimism of Joachim's time of earthly happiness, but argued that the latter stemmed from non-western Sibylline and Tiburtine texts and from 12thcentury reworkings of the ideas of Jerome and Bede. In particular he identified Jerome as the inadvertent originator of the notion of a continuation of earthly history before the coming of the Antichrist, an idea transformed in the 12th century and perpetuated through widely disseminated texts such as the Glossa ordinaria. ${ }^{18}$

Numerous more recent historians have echoed this line, tending to downplay Joachim's posthumous influence. Luigi Canetti is typical when, in a discussion of the work of the Dominican Petrus Ferrandi (d. before 1258), he argues that the eschatology of Ferrandi's text cannot be ascribed to anything more than a generic revitalizing, already from the early 1200s, of a broader current of eschatology in the

\footnotetext{
${ }^{14}$ Henri de Lubac, La Postérité spirituelle de Joachim de Flore, 2 vols. (Paris, 1979-81). For Buonaiuti and Grundmann, see notes 13 and 77. Bernard McGinn also provides an excellent brief account of their views in "Influence and Importance in Evaluating Joachim of Fiore," pp. 15-18. See now also Matthias Riedl, Joachim von Fiore. Denker der vollendeten Menschbeit (Epistemata: Würzburger wissenschaftliche Schriften: Reihe Philosophie, 361) (Würzburg, 2004).

${ }^{15}$ Marjorie Reeves, The Influence of Prophecy in the Later Middle Ages: a Study in Joachimism (Oxford, 1969), p. 303. On the roots of Reeves' approach see R.W. Southern, "Marjorie Reeves as a Historian," in Prophecy and Millenarianism: Essays in Honour of Marjorie Reeves, ed. Ann Williams (Harlow, 1980), pp. 1-9, reprinted in History and Historians. Selected Papers of R. W. Southern, ed. R.J. Bartlett (Oxford, 2004), pp. 218-224. Other important and influential historians in the field include Bernhard Töpfer, whose Das kommende Reich des Friedens. Zur Entwicklung chiliastischer Zukunftshoffnungen im Hochmittelatler (Berlin, 1964), was reprinted nearly thirty years later, translated into Italian by Sergio Sorrentino (with a useful preface by Töpfer updating the historiography), as Il regno futuro della libertà. Lo sviluppo delle speranze millenaristiche nel medioevo centrale (Opere di Gioacchino da Fiore: strumenti, 4) (Genoa, 1992).

${ }^{16}$ Raoul Manselli, Premise to "Richerche sull'influenza della profezia nel Medioevo," Bullettino dell'Istituto storico Italiano per il Medio Evo 82 (1970), 1-12.

${ }^{17}$ Robert E. Lerner, "Refreshment of the Saints: the Time after Antichrist as a Station for Earthly Progress in Medieval Thought," Traditio 32 (1976), 97-144, 101, 117.

${ }^{18}$ Ibid., 101-115. For a recent introduction to the early texts on the Antichrist, see Gian Luca Potestà and Marco Rizzi, eds., L'anticristo, vol. 1: Il nemico dei tempi finali. Testi dal II al IV secolo (Milan, 2005).
} 
traditional Augustinian-Gregorian matrix. ${ }^{19}$ For Canetti, this trend helps to explain the rapid fortune of Joachite writings and motifs and their easy acceptability at various levels of theological learning. ${ }^{20}$ Other recent writers have sought to sidestep the difficulties inherent in tracing the reception of specific ideas and influence by detaching origin and impact. Thus for Raniero Orioli, Joachim was the spokesperson of a profound religious need and his prophetic hope was to persist--even though reelaborated and reinterpreted--"in all the spiritual and religious tensions which came later." Joachism is, however, to be understood in the widest sense, as simply characterizing the climate of religious expectation: "the joachism of the mid-thirteenth century was the joachism of joachites, not that of Joachim." ${ }^{21}$ There is, to follow this line of thought, no need to explore the reception of Joachim's specific thinking: it is enough to acknowledge that ideas evolved and that both Joachim and other writers were participating in a new phase of creativity in eschatological thinking, less determined by the Augustinian-Gregorian matrix. ${ }^{22}$

There is however, more to be said about Joachim's originality. Since the 1970s Lerner has revised his thinking and underlined revolutionary aspects of Joachim's approach, for example in his changes to the Antichrist theology of the 10th-century De ortu et tempore Antichristi (traditionally identified as by Adso of Montier-en-Der, Adso Dervensis), his unprecedented interpretation of the Book of Revelation as a sustained work of prophecy, or his audacity and doctrinal independence in ignoring Augustine's opinion that an earthly paradise amounted to "ridiculous tales." 23 Paul J. Alexander has also brought his expertise on Byzantine apocalyptic sources to bear on the debate about Joachim's influence by examining potential links. ${ }^{24} \mathrm{He}$ concludes

\footnotetext{
${ }^{19}$ Luigi Canetti, L'invenzione della memoria. Il culto e l'immagine di Domenico nella storia dei primi frati Predicatori (Spoleto, 1996), p. 346. For Ferrandi's dates, see Simon Tugwell, "Petrus Ferrandi and His Legenda of St. Dominic," Archivum Fratrum Praedicatorum 77 (2007), 19-100, 60. On Ferrandi, see also below, text at note 140 .

${ }^{20}$ Canetti, L'invenzione della memoria, p. 346.

${ }^{21}$ Raniero Orioli, Venit perfidus heresiarcha. Il movimento apostolico-dolciniano dal 1260 al 1307 (Studi Storici, 193-196) (Rome, 1988), p. 45 (and citing Manselli, Premise to "Ricerche," p. 9 [see note 16 above]).

${ }^{22}$ For the idea of an earlier 'take-off' in apocalyptically-tinged eschatology, in the 10th and 11th centuries, see Johannes Fried, "Endzeiterwartung um die Jahrtausendwende," in Deutsches Archiv für Erforschung des Mittelalters 45 (1989), 381-473, also published in Italian as, 'L'attesa della fine dei tempi alla svolta del millennio', in L'attesa della fine dei tempi nel medioevo, eds. Ovidio Capitani and Jürgen Miethke (Annali dell'Istituto storico italo-germanico Quaderno, 28) (Bologna, 1990), 37-86.

${ }^{23}$ See Robert E. Lerner, "Antichrists and Antichrist in Joachim of Fiore," Speculum 60 (1985), 553-570 and Idem, "Ecstatic Dissent," Speculum 67 (1992), 33-57, 40. For his earlier, more restricted view of Joachim's influence, see Idem, "Refreshment of the Saints," 120-123. A summary of Lerner's change of approach is in Felice Accrocca, "Intorno ad alcuni recenti studi gioachimiti," Rivista di Storia della Chiesa in Italia 51 (1997), 149-174, 164. For a new and convincing hypothesis on the origins and purpose of De ortu et tempore Antichristi and the identity of its author, who is named in early sources only as Adso, see Simon Maclean "Reform, Queenship and the End of the World in Tenth-Century France: Adso's 'Letter on the Origin and Time of the Antichrist' Reconsidered", Revue belge de philologie et d'histoire / Belgisch tijdschrift voor filologie en geschiedenis 86 (2008), 645-675.

${ }^{24}$ Paul J. Alexander, "The Diffusion of Byzantine Apocalpyses in the Medieval West and the Beginnings of Joachism," in Prophecy and Millenarianism. Essays in Honour of Marjorie Reeves, ed. Ann Williams (Harlow, 1980), pp. 53-106. See also Idem, "Byzantium and the Migration of Literary Works and
} 
that they must have been known to, but deliberately ignored by, Joachim, who was hostile both to Greek Christianity and to an apocalyptic tradition which developed independently from the canonical Revelation of John. ${ }^{25}$ At the end of the 1990s, Julia Eva Wannenmacher further detailed the way in which Joachim broke with tradition by arguing, for example, that the Eschaton had already begun with the history of salvation. ${ }^{26}$ She also reminded scholars that there is no clear line separating the three status in his thought, so that "events in the seventh part of the Apocalypse, such as the work of Gog and the Last Judgement, belong in part to the second, in part to the third status." ${ }^{27}$ For Joachim the Antichrist is not the beginning of the end, but a milestone in salvation history. ${ }^{28}$ In the process Wannenmacher corrects an earlier oversimplification proposed by Manselli, who had argued that Joachim allowed for a double Antichrist: a first in the period of transition from the second to the third status, which behaved as a "universalis pontifex" and a second which would appear at the close of the third status just before the Last Judgement at the end of days, and was to be identified with Gog or with the tail of the dragon in the Apocalypse. ${ }^{29}$ More recently still and following a similar line of analysis, Gian Luca Potestà has revisited versions of the Antichrist in texts which were "best-sellers" of the late 11th and early 12th centuries. Renewed comparison with the 4th-century Tiburtine Sibyl produced in the eastern Mediterranean, the 7th-century Mesopotamian Revelationes of pseudoMethodius, and Adso's De ortu et tempore Antichristi allow him to argue that Joachim contributed to a redefinition by maintaining the notion of the Antichrist as a single being (as against Augustine's idea--for example--of a collective entity) and, like Hildegard of Bingen, ignoring the other tradition, that of last emperor. Potestà thus concludes--rather more like Reeves--that it would not be possible to explain the interest that Joachim's message later aroused without acknowledging his role in the conceptual and lexical modernizing of eschatology and prophecy. ${ }^{30}$

Motifs: the Legend of the Last Roman Emperor," Medievalia et Humanistica, n.s. 2 (1971), 47-68; reprinted in Religious and Political History and Thought in the Byzantine Empire. Collected Essays of Paul J. Alexander (Variorum Collected Studies Series, 71) (London, 1978), Essay XII; Idem, "Medieval Apocalypses as Historical Sources,"

American Historical Review 73, no. 4 (1968), 997-1018, reprinted in Religious and Political History and Thought, Essay XIII; Idem, The Oracle of Baalbek: the Tiburtine Sibyl in Greek Dress (Dumbarton Oaks Center for Byzantine Studies, 10) (Washington D.C., 1967).

${ }^{25}$ Alexander, "The Diffusion of Byzantine Apocalpyses," pp. 84-86.

${ }^{26}$ See Wannenmacher, "Die Macht des Bösen," p. 376.

${ }^{27}$ Ibid. She underlines the almost revolutionary nature of Joachim's interpretation of the Antichrist opening the Seventh aetas and its implications for the thousand years to follow in Wannenmacher, 'Apocalypse, Antichrists and the Third Age' pp. 276-278.

${ }^{28}$ Ibid., p. 378.

${ }^{29}$ Ibid., p. 372, with reference to Raoul Manselli, "Il problema del doppio anticristo in Gioacchino da Fiore," in Geschichtschreibung und geistiges Leben im Mittelalter. Festschrift für Heinz Löwe zum 65. Geburtstag (Cologne-Vienna, 1978), pp. 427-449, p. 434; reprinted in Idem, Da Gioacchino da Fiore a Cristoforo Colombo. Studi sul francescanesimo spirituale, sull'ecclesiologia e sull'escatologismo bassomedievali, intro. and ed. Paolo Vian (Istituto storico italiano per il medio evo: Nuovi studi storici, 36) (Roma 1997), pp. 509-532, p. 519.

${ }^{30}$ Potestà, "Gli spazi dell'Anticristo," p. 420. 
As these and other historians have demonstrated, Joachim's work was part of a continuum of ideas concerning the Apocalypse and biblical exegesis which were endlessly subject to reappropriation and rewriting. Although innovative, he had no monopoly on apocalyptic thought and, like his contemporaries and successors, was surely reacting above all to events in his lifetime of the sort with which this chapter began. ${ }^{31}$ Yet--as will become clear in the following exploration of the mechanisms for the transmission of his thinking and the ways in which it was exploited--it was to be Joachim's name that acquired great resonance. It remains legitimate to ask what triggered that process. A premise of this chapter is that the answer must be sought in the particular contribution of, and responses to, Abbot Joachim as a personality, but above all as a creative thinker.

Joachim's personal reputation as a living (and controversial), religious authority, an expert on the Antichrist, was high. In the final decades of his life, he was to be found in the company of pope and curia. He visited Lucius III in Veroli in 1184 and his successor Urban III in Verona in 1186-7. In 1188 he met Clement III in Rome and his work was known to Innocent III (1198-1216). ${ }^{32}$ These contacts have been used to suggest various possible lines of influence. His views on the religious life--to take just one example--have been proposed as Innocent III's source for the inclusion of married men and women in the tripartite division of the new order of the Humiliati, approved in 1201, a year before Joachim died. ${ }^{33}$ As well as his Trinitarian division of the history of the Church, Joachim had argued that there were three levels of monastic practice: those who are most like "animals" (carnal) were to do manual

\footnotetext{
${ }^{31}$ An example of an eschatological work which "proves that 'post-Antichrist' chiliasm could exist in the thirteenth century apart from Joachim of Fiore," is the Aser pinguis, written in the circle of the Dominican Hugh of Saint Cher c.1236. The author knew Joachim's writings, but chose instead to use Richard of Saint Victor's Revelation commentary, in turn based on Bede. See Robert E. Lerner, "Poverty, Preaching, and Eschatology in the Revelation Commentaries of 'Hugh of St. Cher," in The Bible in the Medieval World. Essays in Memory of Beryl Smalley, eds. Katherine Walsh and Diana Wood (Oxford, 1985), pp. 157-189, esp. pp. 179-180. See also David Burr, "The Antichrist and the Jews in Four Thirteenth-Century Apocalypse Commentaries," in The Friars and the Jewes in the Middle Ages and the Renaissance, eds. Steven J. Michael and Susan E. Myers (The Medieval Franciscans, 2) (LeidenBoston, 2004), pp. 23-38. On the Aser pinguis, see also below, text at note 143.

${ }^{32}$ The encounters are documented both in contemporary chronicles (on which see below) and in a letter of Clement III of 1188. See Herbert Grundmann, "Joachim von Floris und Rainer von Ponza," Deutsches Archiv für Erforschung des Mittelalters 16 (1960), 437-546, 492-493. Joachim's so-called lettertestament also refers to letters from Popes Lucius III, Urban III, and Clement III asking him to complete his writings and submit them for approval. For the debate about the authenticity of this text, see Reeves, The Influence of Prophecy, pp. 28-29 note 3. It is accepted by Kurt-Victor Selge, "L'origine delle opere di Gioacchino da Fiore," in L'attesa della fine dei tempi nel medioevo, eds. Capitani and Miethke (as note 1), pp. 87-131, p. 93. A list of those whom Joachim met is in Bernard McGinn, "Joachim and the Sibyl," Citeaux 24 (1973), 97-138, 97 note 3; and repeated in Robert Moynihan, "Joachim of Fiore and the Early Franciscans: a Study of the Commentary 'Super Hieremiam,"” 2 vols. (PhD diss., Yale, 1988), vol. 1, pp. 25-26.

${ }^{33}$ See Fiona Robb, “'Who Hath Chosen the Better Part?' (Luke 10,42): Pope Innocent III and Joachim of Fiore on the Diverse Forms of Religious Life," Monastic Studies 2 (1991), 157-170, 158.
} 
labor, those in the middle were to study doctrine and those who were spiritual, the peace of contemplation. ${ }^{34}$ The superficial parallels with the lay, monastic, and canonical elements of the Humiliati order are intriguing, but there is little evidence for the study of doctrine among the Humiliati at this date and pragmatic considerations must have played a large part in settling on their new structure, responsibility for which lay as much with the north Italian Humiliati themselves as with the prelates entrusted by Innocent with bringing them back into the Church. ${ }^{35}$ In a recent biography of Joachim, moreover, Potestà has observed that the early policies of Innocent III, on issues such as heretics, Jews, and the Eastern Church, do not indicate that his policies were much influenced by the views of the Calabrian abbot. ${ }^{36}$ Nonetheless, Innocent did borrow from Joachim in his own writings, for example in his use of number symbolism. ${ }^{37}$ The connection was almost certainly indirect, through Joachim's former companion Raniero da Ponza, who was to become a prominent figure in Innocent's curia. It is a model of transmission which was often to be repeated.

Joachim was reputed to have enjoyed similar fame at royal courts, but once again, it is not easy to ascribe any direct impact. The English chronicler Roger of Howden (d. 1201/2) reports that while at Messina in 1190, King Richard of England sent for Joachim. The king was keen to hear his prophecies, having heard much about his reputation. ${ }^{38}$ The abbot was also said to have encountered Philip Augustus of France and, at a more down-to-earth level, in 1190-91, he petitioned King Tancred of Sicily, from whom he requested protection and fiscal exemptions for his monks. ${ }^{39}$

\footnotetext{
34 "Illis enim qui animales sunt in monasteriis imponendum est opus manuum, illis qui medii studium doctrine, illis qui spiritualibus requies contemplationis." Joachim of Fiore, Liber de Concordia Novi ac Veteri Testamenti 5, cited in Lerner, "Joachim and the Scholastics," in Gioacchino da Fiore tra Bernardo di Clairvaux e Innocenzo III (as note 12) pp. 251- 264, p. 261.

${ }^{35}$ On the reconciliation of the Humiliati, see Frances Andrews, The Early Humiliati (Cambridge, 1999), pp. 64-98.

${ }^{36}$ Gian Luca Potestà, Il tempo dell'Apocalisse. Vita di Gioacchino da Fiore (Rome-Bari, 2004). See also Gian Luca Potestà, "Joachim de Flore dans la recherche actuelle," Oliviana, put online 27 June 2006. URL: http://oliviana.revues.org/document39.html.

${ }^{37}$ Fiona Robb, "Joachimist Exegesis in the Theology of Innocent III and Rainer of Ponza," Florensia 11 (1997), 137-152, 152. See also Christoph Egger, "Papst Innocenz III. als Theologe. Beiträge zur Kenntnis seines Denkens im Rahmen der Frühscholastik," Archivum Historiae Pontificiae 30 (1992), 55-123, 106109 on Innocent's use of the same IEUE Tetragram as Joachim; Idem, "A Theologian at Work: Some Remarks on Methods and Sources in Innocent III's Writings," in Pope Innocent III and His World, ed. John C. Moore (Aldershot, 1999), pp. 25-33; Idem, "Joachim von Fiore, Rainer von Ponza und die römische Kurie," in Gioacchino da Fiore tra Bernardo di Clairvaux e Innocenzo III, pp. 129-162; Fiona Robb, "Did Innocent III Personally Condemn Joachim of Fiore?” Florensia 7 (1993), 71-91; Christoph Egger, "Joachim von Fiore, Rainer von Ponza und die römische Kurie", in Gioacchino da Fiore tra Bernardo di Clairvaux e Innocenzo III, 129-162.

${ }^{38}$ Roger of Hoveden/Howden, Chronica, ed. W. Stubbs (Rerum Britannicarum Medii Aevi Scriptores, 51) (London, 1868-71), vol. 3 pp. 75-79; and Gesta Regis Ricardi, ed. W. Stubbs (Rerum Britannicarum Medii Aevi Scriptores, 49) (London, 1867), vol. 2 pp. 151-155. See also Reeves, The Influence of Prophecy, p. 7.

${ }^{39}$ On Philip, see below, text at notes 47 and 90 . On Tancred, see the Vita beati Joachimi abbatis, ed. Herbert Grundmann, "Zür Biographie Joachims von Fiore und Rainers von Ponza," in Deutsches Archiv für Erforschung des Mittelalters 16 (1960), 437-546; reprinted in Idem, Ausgewäblte Aufsätze, vol. 2
} 
According to an anonymous vita written by a close companion in the first decade of the 13th century, Joachim counseled the Emperor, Henry VI, proposing that he break off a particularly violent siege of Naples and return at a later date, when he would win Sicily without a fight (sine bello), as indeed he did. ${ }^{40}$ Finally, after Henry's death, Joachim may have attended the court in Palermo of his widow, Constance, and later, of their young son, Frederick (II). Reports in contemporary chronicles of these encounters are an important vehicle for understanding the nature and geographical extent of the abbot's fama. But a lack of corroborating sources means, even allowing for the agendas of the writers, the immediate political or spiritual impact of such personal contacts themselves, if any, is beyond retrieval. ${ }^{41}$

In the world of the schools, we seem at the outset to be on firmer ground. As Philippe Buc first noticed, the Paris Master, Peter the Chanter (d. 1197), in his Commentary on Exodus, criticized Joachim's method of comparing the Church in the Old and New Testaments:

Accordingly, that Joachim, comparing the status of the Church before the coming of Christ, whereby, after the coming of Christ, the status and experience [of the Church] are completed, proclaims that the coming of the Antichrist is now imminent, when the good will be completed and destroyed. But this comparison is unprofitable and inconsistent. ${ }^{42}$

pp. 255-360, p. 349. The royal diploma is now printed in Valeria de Fraja, Oltre Citteaux. Gioacchino da Fiore e l'Ordine florense (Rome, 2006), p. 202.

${ }^{40}$ The account of Joachim's encounter with Henry is in the Vita b. Joachimi abbatis, ed. Grundmann, pp. 350-351. Pietro da Eboli, a loyal member of the court of Henry VI, who wrote a poem celebrating his taking of Sicily, was, according to the modern editor of his poems, open to Joachite ideas already during the abbot's lifetime. If so, they were reflected only in a very allusive manner in his writing. See Petri Ansolini de Ebulo, "De rebus Siculis carmen," ed. E. Rota, Rerum Italicarum Scriptores, second series, 31/1 (Città di Castello, 1904), particula xlii, pp. 177-178 and particula xlvii, p. 193. See also Enrico Pispisa, Gioacchino da Fiore e i Cronisti Medievali (Messina, 1988), p. 50. On Henry VI's contact with Joachim and interest in prophecies of the end of time see now also Thomas Foerster, 'Der Prophet und der Kaiser: Staufische Herrschaftsvorstellungen am Ende des 12. Jahrhunderts', in Staufisches Kaisertum im 12 Jabrhundert: Konzepte - Netzwerke - Politische Praxis, eds. Stefan Burkhardt, Thomas Metz, Bernd Schneidmüller and Stefan Weinfurter (Regensburg, 2010) pp. 253-276.

${ }^{41}$ Hubert Houben cautiously notes that the encounters with Richard, Henry VI, and Constance are recorded by single contemporary chroniclers or by hagiographical texts which are "notoriamente ... pieni di topoi letterari e di ambigua valenza ..." in "Monarchia normanno-sveva e Ordini riformati (con alcune considerazioni sulla religiosità di Federico II)," in Gioachimismo e profetismo in Sicilia (secoli xiiixvi). Atti del III Convegno internazionale di studio (14-16 October 2005), ed. Cosimo Damiano Fonseca (Rome, 2007), pp. 15-28, p. 18.

${ }^{42}$ Peter the Chanter, Commentary on Exodus, cited in Philippe Buc, L'ambiguité du livre. Prince, pouvoir, et peuple dans les commentaires de la bible au moyen age (Théologie historique, 95) (Paris, 1994), p. 164 note 96: "Sic et ille Ioachim comparans status ecclesie ante adventum Christi, in quo consummato [fuit] statibus et eventibus eius [ecclesie] post adventum Christi predicat iam imminere adventum antichristi in qua consummatio et destructio boni [bonorum]. Sed predicta comparatio inutilis videtur et incongrua." Discussed in Robert E. Lerner, "Joachim and the Scholastics," p. 256. 
It is an indisputably negative reaction, but the Chanter's words demonstrate all the same that Joachim's thinking had already reached one of the leading masters in Paris, whether by word of mouth, in writing, or by images. Indeed, it seems likely that Joachim's more complex ideas arrived in Paris and elsewhere on manuscript folia and, though not yet collected into a single volume, that this may have included images (figurae) through which, as Reeves argued, "Joachim's ideas were mostly widely disseminated." "3 Once more, however, tracing their impact in the political or religious world beyond the Chanter's circle is not easy. ${ }^{44}$ As Lerner argues, the evidence for Peter's knowledge of Joachim's approach means his thinking may also have been known to Amalric of Bène, another Paris Master (d. 1206), as well as to Cardinal Robert of Courson, who was to be involved in the later condemnation of Amalric and his forced recantation, disgust at which appears to have provoked the latter's death, brought about by "weariness ... and indignation" (tedio ... et indignatione affectus). ${ }^{45}$ Courson had been one of the Chanter's circle, so he may have been warned against Joachim early on. ${ }^{46}$ Contemplating stories of the supposed encounter between Joachim and Philip Augustus in Messina, Gary Dickson also suggests that it "can be taken for granted that Capetian court circles [where Amalric was a tutor to the future king] would not have been unacquainted with the outlines of Joachism." ${ }^{47}$ Yet the uncertainties give pause. There is indeed some evidence for the French royal court knowing about Joachism: a poem composed "quasi prophetice" on the king before his crusade, brings to mind his preaching. ${ }^{48}$ Dickson rightly concludes however, that "in reality, none of [the] arguments for Amalric's putative knowledge of Joachism can bear much scrutiny. No proof exists that Amalric was informed about Joachite exegesis or prophecy, even if his adherents were." He also points out how unlikely it

\footnotetext{
${ }^{43}$ Reeves, The Influence of Prophecy, pp. 27, 38. Some of Joachim's works later circulated together with those of the Chanter. See, for example, Gioacchino da Fiore, Introduzione all'Apocalisse, ed. Kurt-Victor Selge (Opere di Gioacchino da Fiore: testi e strumenti, 6) (Rome, 1995) with reference to Paris, Bibliothèque nationale de France [hereafter BnF], lat. 682 from the early 13th century and Rein, Austria, Zisterzienserstiftsbibliothek, MS 61 from the late 13th century. Albertus Magnus was to stress the role of images in conveying dreams, visions, and prophecies, which were "imprinted on the sensitive soul," in his "De Somno et vigilia," ed. Borguet. See Roest, "Divination, Visions and Prophecy according to Albert the Great," pp. 327-328.

${ }^{44}$ For this terminology see John W. Baldwin, Masters, Princes, and Merchants: the Social Viewes of Peter the Chanter $\&$ His Circle (Princeton, 1970).

${ }^{45}$ Guillaume le Breton, "Gesta Philippi Augusti (continuation)," in Oeuvres de Rigord et de Guillaume le Breton, Historiens de Philippe-Auguste 1, ed. Henri F. Delaborde (Paris, 1882), pp. 168-375, p. 231; see also J.M.M.H. Thijssen, "Master Amalric and the Amalricians: Inquisitorial Procedure and the Suppression of Heresy at the University of Paris," Speculum 71 (1996), 43-65, 48.

${ }^{46}$ Lerner, "Joachim and the Scholastics," pp. 251- 264; Thijssen, "Master Amalric and the Amalricians," pp. $43-65$.

${ }^{47}$ Gary Dickson, “The Burning of the Amalricians,” The Journal of Ecclesiastical History 40 (1989), 347369, 363; repr. in Idem, Religious Enthusiasm in the Medieval West, Variorum Collected Studies Series 695 (Aldershot, 2000), Essay III.

${ }^{48}$ As observed by E.A.R. Brown, "La notion de la legitimité et la prophetie à la cour de Philippe Auguste," in La France de Philippe Auguste, ed. R.-H. Bautier (Paris, 1982), p. 85. The poem is now in Rigord, Histoire de Philippe Auguste, ed., trans., and notes by É. Carpentier, G. Pons, and Y. Chauvin (Sources d'Histoire Médiévales, 33) (Paris, 2006), pp. 265-267. The editors remark that the poem also draws on Hebrew prophecies, ibid., p. 86.
} 
is that Amalric would have attempted to combine Joachim's dynamic version of biblical-historical prophecy with his own "static, metaphysical world view of neoplatonic Christian pantheism." ${ }^{49}$ The link becomes no less speculative if we turn to the beliefs of Amalric's clerical adherents, who were to be condemned and burnt in 1210, when their master's body too was disinterred and excommunicated. According to the Contra Amaurianos (c. 1208-10), a hostile account of their beliefs attributed to Guarnerius of Rochefort, they considered themselves to have a special role as spiritual figures who did not need grace or penance to be saved, and argued, for example, that within five years all men would be spirituales. ${ }^{50}$ To judge by his extant writings, such ideas would have amazed Joachim. Yet the Amalricians also believed that the Third Age, one of spiritual progress, had arrived. According to the Cistercian Caesarius of Heisterbach, moreover, one of their number, William Aurifaber, prophesied concerning the Antichrist. ${ }^{51}$ Were he and his companions aware of Joachim's division of history into three, or his predictions concerning the Antichrist and spiritual men? Perhaps. The difficulty is, once again, that Joachim was not writing in a vacuum. As well as those already mentioned, numerous other writers had had similar notions about structuring time, or the chronology and effect of the coming of an Antichrist. Rupert of Deutz (d. 1129), to take an influential case, had used typologies in his exegesis of the Bible to associate the three persons of the Trinity with periods of history, relating God the Father to the Creation, Christ to Redemption (culminating in the incarnation), and the Holy Spirit to the history of the Church. ${ }^{52}$ Another theologian and keen monastic reformer, Gerhoh, provost of Reichersberg (d. 1169) had deployed similar typological exegesis and written of "spiritual men."

Summarizing the contours of Joachim's posthumous impact and reputation is further complicated by the difficult legacy of the events of the Fourth Lateran Council

\footnotetext{
${ }^{49}$ Dickson, "Burning of the Amalricians," 363.

${ }^{50}$ See Contra amaurianos: ein anonymer, wabrscheinlich dem Garnerius von Rochefort zugehöriger Traktat gegen die Amalrikaner aus dem Anfang des XIII. Jahrbunderts, ed. Clemens Baeumker (Münster, 1926). The likely date is discussed on pp. xvii-xxv.

${ }^{51}$ Caesarius of Heisterbach, "De hereticis Parisiis exustis," in Dialogus Miraculorum 5.22, ed. J. Strange, 2 vols. (Cologne, 1851), vol. 1, pp. 304-307, p. 305.

${ }^{52}$ Ruperti Tuitiensis [Rupert of Deutz], De Sancta Trinitate et operibus eius, ed. Rhabanus M. Haacke, 4 vols. (Corpus Christianorum: series latina continuatio mediaevalis, 21-24) (Turnholt, 1971-1972), esp. vol. 1, introduction. See also Peter Classen, "Res Gestae, Universal History, Apocalypse. Visions of Past and Future," in Renaissance and Renewal in the Trwelfth Century, eds. Robert L. Benson and Giles Constable with Carol D. Lanham (Cambridge, Mass., 1982; repr. Medieval Academy of America, University of Toronto Press, 1991), pp. 387-417, p. 405.

${ }^{53}$ Peter Classen argued against seeing these as eschatologically significant, in contrast to the work on representations of the Antichrist by Horst Dieter Rauh. See Peter Classen, "Eschatologische Ideen und Armutsbewegungen im 11. und 12. Jahrhundert," in Povertà e ricchezza nella spiritualità dei secoli XI e XII (Convegni del Centro di Studi sulla Spiritualità Medievale) 8 (Todi, 1969), pp. 127-162, reprinted in Ausgewählte Aufsätze von Peter Classen, ed. J Fleckenstein, assisted by Carl Joachim Classen and Johannes Fried (Vorträge und Forschungen, 28) (Sigmaringen, 1983), pp. 307-326, p. 324; H.D. Rauh, Das Bild des Antichrist im Mittelalter. Von Tyconius zum deutschen Symbolismus (Münster, 1973), p. 506. For a brief account of his views, see also Classen, "Res Gestae, Universal History, Apocalypse. Visions of Past and Future," pp. 387-417.
} 
in 1215 , which saw the condemnation of his ideas on the Trinity. ${ }^{54}$ Joachim was hostile to Scholasticism, which he considered an inferior means of discerning spiritual truth, and had attacked the views expressed in the Sentences by the scholastic theologian and Bishop of Paris, Peter Lombard (d. 1160). He insisted on the unity of the Trinity, rejecting Peter's argument for a "divine essence" as creating a fourth element and an evidently absurd "Quaternity." He was even to accuse Peter of blasphemy. In a subtle passage, however, the constitutions issued by the Council adopted the views of the Lombard, rejecting Joachim's conservative criticisms. ${ }^{55}$ Unlike the same text's denunciation of the "wicked teaching of the impious Amalric" (perversissimum dogma impii Amalrici), there was no condemnation of Joachim himself. The constitution also affirmed that there was no wish to undermine the Monastery of Fiore founded by Joachim, since it was a "wholesome observance," and (potentially more embarrassing) since Joachim had had all his writings sent to the pope for approval or correction. ${ }^{56}$ There seem not to have been open enemies of Joachim at the Council and Honorius III (1216-1227), who had attended it as a Cardinal, was to issue letters defending the abbot's reputation. ${ }^{57}$ In 1216 , for example, the bishop of Lucca, who had previously accused Joachim and the Florensians of heresy, was warned to desist. In 1220 the pope instructed the Archbishop of Cosenza (Luca, Joachim's former companion) and the Bishop of Bisignano to defend the memory of Joachim from accusations of heresy based on the Lateran condemnation of the libellus (booklet) which Joachim had written against Peter Lombard. ${ }^{58}$ The offending Trinitarian text itself does not survive. Indeed, it may simply have been an excerpt from his Psalterium decem chordarum and never have existed as a separate work, but the fact of the condemnation was broadcast both in its original form as part of the constitutions of 1215 and by its inclusion soon after in decretal collections, where it was subject to commentaries and glosses by later canon lawyers. These often pointed out the heresy but also that the Florensians were not condemned or reiterated that Joachim had himself submitted his work to the curia. ${ }^{59}$ As Reeves pointed out,

\footnotetext{
${ }^{54}$ See the chapter by Peter Gemeinhardt in the present volume.

${ }^{55}$ Lerner, "Joachim and the Scholastics," pp. 255-258 posits a link between the Lateran decree and Parisian scholastics; see also Alain Boureau, "Le concept de relation chez Pierre de Jean Olivi," in Pierre de Jean Olivi (1248-1298). Pensée scolastique, dissidence spirituelle et société, Actes du colloque de Narbonne (March 1998), eds. Alain Boureau and Sylvain Piron (Paris, 1999), pp. 41-55, p. 46.

${ }^{56}$ See also the evidence of the Letter-Testament, above note 32.

${ }^{57}$ Reeves, The Influence of Prophecy, p. 32. Honorius III's attendance at the Fourth Lateran Council, as Cencius, Cardinal-Bishop of SS Giovanni e Paolo, is recorded in Achille Luchaire, "Un document retrouvé," Le Journal des Savants, n.s. 3 (1905), 557-567, 561.

${ }^{58}$ The bulls are now printed in De Fraja, Oltre Citeaux, pp. 265-266 and 272-273 (as note 39 above).

${ }^{59}$ See for example the commentary on constitution 2 in the Casus Fuldensis, edited in Antonio García y García, Constitutiones Concilii quarti Lateranensis una cum Commentariis glossatorum, Monumenta Iuris Canonici, Series A: Corpus Glossatorum, vol. 2 (Città del Vaticano 1981), pp. 483-492, p. 483: "In secunda parte dicitur quod quicumque voluerit defendere vel approbare sententiam Joachim, ab omnibus tanquam hereticus evitetur, set tamen propter hoc non derogetur monasterio suo ..." See also Pierre Michaud-Quantin, "Commentaires sur les deux premières décrétales du recueil de Grégoire IX au XIIIème siècle," in Die Metaphysik im Mittelalter. Ibr Ursprung und ibre Bedeutung, ed. Paul Wilpert (Miscellanea mediaevalia, 2) (Berlin, 1963), pp. 103-109, p. 105. The transmission of the Lateran decrees to Germany via synods and episcopal action is outlined in Paul B. Pixton, The German Episcopacy and
} 
there was thus to be some separation in the second generation after Joachim between those who focused their memories on the attack on Peter Lombard and the condemnation of 1215, and those who were most interested in his reputation as a biblical exegete. ${ }^{60}$

A final obstacle to clarity about the mechanisms and chronology of the spread of Joachim's influence in the 1200s is simply the piecemeal nature of the evidence. This remains the case despite the work that has been done since 1954, when Morton Bloomfield and Marjorie Reeves observed that the impact of Joachim in the first half of the century remained "somewhat obscure." ${ }^{61}$ Then, as now, the majority of known manuscripts of either Joachim or pseudo-Joachim came from Italy and France. ${ }^{62}$ This is probably a fair indication of the original foci of his impact, but there must have been other manuscripts, and in other places. An early copy of the Psalterium decem chordarum and the Liber introductorius has recently been redated to the late 12th century and found to include the hands of Spanish scribes. If this is right, it is not impossible that it was prepared for distribution at the instruction of Joachim's friend and colleague, Raniero da Ponza, when he served as Innocent III's legate to Navarre in 1198-99..$^{63}$ A chapter of the Prephatio super Apocalypsim was copied in a manuscript belonging to the Monastery of Saint-Amand en Pévèle near Valenciennes and dated 1198. ${ }^{64}$ These seem, however, to be rare early survivals. A disastrous fire at Joachim's monastery of San Giovanni in Fiore in 1214, which destroyed administrative documents and led the monks to move to a new site, may well have devastated much of the library, while the very existence of a scriptorium at the monastery is disputed. ${ }^{65}$ The Liber de Concordia, Psalterium decem chordarum, Tractatus super quatuor Evangelia, a few shorter works and the Commentary on the Apocalypse were all copied, between the second and third decades of the 13th century in the scriptoria of the Cistercian houses of Corazzo (where Joachim had been abbot) and Santa Maria della Sambucina in Calabria. ${ }^{66}$ But when E. Randolph Daniel listed twenty complete and

the Implementation of the Decrees of the Fourth Lateran Council, 1216-1245: Watchmen on the Tower (Leiden-New York, 1995).

${ }^{60}$ Reeves, The Influence of Prophecy, pp. 45-46.

${ }^{61}$ Morton W. Bloomfield and Marjorie E. Reeves, "The Penetration of Joachism into Northern Europe," Speculum 29 (1954), 772-793, 772.

${ }^{62}$ See, for example, Sabine Schmolinsky, Der Apokalypsenkommentar des Alexander Minorita: zur frühen Rezeption Joachims von Fiore in Deutschland (Hanover, 1991), p. 9.

${ }^{63}$ Paris, BnF, MS 427. The association is proposed by Fabio Troncarelli, "Un autografo di Ranerio da Ponza," in Il Ricordo del Futuro. Gioacchino da Fiore e il Gioachimismo attraverso la storia, ed. Fabio Troncarelli (Bari, 2006), pp. 47-53.

${ }^{64}$ Valenciennes, Bibliothèque municipale, MS 516. See Gioacchino da Fiore, Introduzione all'Apocalisse, ed. Selge, pp. 20-21. Selge hypothesizes that the text reached Valenciennes either within the Cistercian order or via copyists from southern Italy. He also notes that it is possible that the manuscript, which also contains works by Ailred of Rievaulx, Bernard of Clairvaux, and various saints' lives and passiones, was produced in southern Italy and only reached Valenciennes in the 13th century. Ibid., p. 21.

${ }^{65}$ See Valeria de Fraja, “'Post combustionis infortunium.' Nuove considerazioni sulla tradizione delle opere gioachimite," Florensia 8-9 (1994-5), 129-171, 131-137, 139.

${ }^{66}$ A.M. Adorisio, Codici latini calabresi. Produzione libraria in Val di Crati e in Sila tra xii e xiii secolo (Rome, 1986), pp. 26-28, 48-50. See below, text at note 109, on Oxford, Corpus Christi College, MS 255A, which contains the Liber de Concordia and was produced at or for San Giovanni in Fiore. Padua, 
four partial manuscript copies of the Liber de Concordia in his modern edition of the text, none of the eleven which he dated to the 13th century could be assigned to the first half. ${ }^{67}$ According to Daniel, one originally belonged to San Giovanni in Fiore, but it was probably produced only in the middle of the century. ${ }^{68}$ Another, written in a north Italian script, belonged to "Fr. R. Gaufridi" whom Daniel identified as probably Raymond Geoffroi (d. 1310), minister general of the Friars Minor (1289-1295), a particularly interesting connection in view of Raymond's advocacy for and identification with the Spiritual Franciscans. ${ }^{69}$ Of the other, late 13th-century manuscripts for which Daniel provides a provenance, two appear to be German, two south Italian, and two are linked to Paris at the end of the century. One of these belonged to the poor Masters of the Sorbonne, to whom it was bequeathed by a Master Gerald of Utrecht. These were undoubtedly key sites for the reception of Joachim in the 13th century, but it is a problematically late and incomplete picture.

Contemporary records of manuscript collections and copying add something to this first, fragmentary account, providing occasional pointers to where other copies may have been and the means by which Joachim's ideas spread. The Franciscan chronicler, Salimbene de Adam, writing in the 1280s and (despite his remarkable garrulity and clear prejudices) one of the best sources for the fortunes of Joachism in the 13th century, informs us that manuscripts of the abbot's works were brought to the Franciscan convent of Pisa in the 1240s, with dramatic consequences for its members. ${ }^{70} \mathrm{He}$ also refers to what appear to be copies of the Liber Figurarum and records that in 1248, when he was in the Franciscan house in Aix, he and his socius copied Joachim's Expositio super IIII evangelistas for John of Parma, the Franciscan Minister General (1247-57), while another Franciscan, Hugh of Digne (d. circa 1285) had copies of all his works, in manuscripts "de grossa littera." ${ }^{71}$ A surviving, undated, letter from yet another Franciscan, the Englishman Adam Marsh (d. 1259) to Bishop Robert Grosseteste of Lincoln (d. 1253), records his loan to Grosseteste of a libellus of Joachim's writings for copying. ${ }^{72}$ Occasional other cases will be mentioned below but,

\footnotetext{
Biblioteca Antoniana, MS 322, which Adorisio dates to the second or third decade of the 13th century and links to Sambucina, contains the Psalterium decem chordarum, Tractatus super quatuor Evangelia, De articulis fidei, Adversus Iudeos, and other minor works.

${ }^{67}$ Abbot Joachim of Fiore, Liber de Concordia, ed. Daniel, pp. xliii-lv.

${ }^{68}$ Rome, Biblioteca Corsiniana, MS 41 F2. Joachim of Fiore, Liber de Concordia, ed. Daniel, p. xliv.

${ }^{69}$ Vatican City, Biblioteca Apostolica Vaticana [hereafter BAV], MS Vat. lat. 4861. Joachim of Fiore, Liber de Concordia, ed. Daniel, p. xliii. According to Angelo Clareno, as Minister General in 1290, Raymond freed the Spirituals of the March who had been imprisoned. Angeli Clareni Opera II Historia Septem Tribulationum ordinis minore, ed. Orietta Rossini, intro. and comm. by Hanno Helbling (Rerum Italicarum Scriptores, Fonti per la storia dell'Italia medievale, 2) (Rome, 1999), Book 6, pp. 223226. On Raymond, see Pierre Péano, "Raymond Geoffroi Ministre général et défenseur des Spirituels," in Picenum Seraphicum. Rivista di studi storici locali 11 (1974), 190-203.

${ }^{70}$ See below, text at note 120. Salimbene de Adam, Cronica, ed. Giuseppe Scalia, 2 vols. (Corpus Christianorum: continuatio mediaevalis, 125-125A) (Turnholt, 1998-9), vol. 1, p. 356.

${ }^{71}$ Salimbene, Cronica, ed. Scalia, pp. 356, 451.

72 The Letters of Adam Marsh, ed. and trans. C.H. Lawrence, 2 vols (Oxford, 2006-2010), vol. 1, Letter 43, pp. 119-120.
} 
like these, most tend to be late. ${ }^{73}$ In view of the numbers of manuscripts surviving from the second half of the century, such activities can only have been the tip of the iceberg. Moreover, the absence of either extant copies of a work, or contemporary references to copies in a particular place, does not mean that the work itself was unknown there, as Peter the Chanter's remark in his Commentary on Exodus demonstrates. The Chanter chose to name his target; others need not. Any attempt to trace such indirect evidence must therefore depend on critical editions of texts by both Joachim and those who may have known his writings, work which is still very much ongoing. ${ }^{74}$ While the scope of Joachim's fama may now be retrievable, a comparable picture of the reception of his thinking is still some way off.

\section{Fama: The Early Chroniclers and the Gift of Spiritual Understanding ${ }^{75}$}

Some of the most convincing and detailed evidence for Joachim's remarkable early reputation comes from three English chroniclers whose interest was sparked by stories of the encounter of Joachim with King Richard, including Roger of Howden, cited above, who also wrote the Gesta regis Henrici secundi. ${ }^{76}$ Roger was a member of the royal court and perhaps an eyewitness to the meeting in Messina. The other two writers were Ralph Niger (who died in or before 1199) and the Cistercian, Ralph of Coggeshall (d. 1227/8), who wrote the Chronicon Anglicanum..$^{77}$ Howden's Gesta,

\footnotetext{
${ }^{73}$ See de Fraja, "Post combustionis infortunium," pp. 129-171; and Eadem, "Una vocazione d'oltralpe: Iohannes de Baiona, monaco florense," Florensia 11 (1997), 41-66.

${ }^{74}$ Since the 1980s a team of German and Italian scholars has been working on modern critical editions of the complete works of Joachim: Valeria de Fraja, Matthias Kaup, Alexander Patschovsky, Gian Luca Potestà, Francesco Santi, Kurt-Victor Selge, Julia Wannenmacher and, more recently, Brigitte Hotz, with advice from Roberto Rusconi, and Robert E. Lerner. See the account by K-V. Selge,

"Presentazione," in Joachim of Fiore, Dialogi de prescientia Dei et predestinatione electorum, ed. Gian Luca Potestà (Fonti per la storia dell'Italia medievale: Antiquitates, 4) (Rome, 1995), pp. xi-xii. Selge is also the editor of the most recent volume to appear: Joachim of Fiore, Psalterium decem cordarum (MGH Quellen zur Geistesgeschichte des Mittelalters, 20) (Hanover, 2009). (MGH editions are now also available on www.dmgh.de with a three-year time lag after the print version). Work has also been undertaken on pseudo-Joachite texts for example by Matthias Kaup (see below). More is needed: the De semine scripturarum, for instance, which circulated in the 13th century as the work of Joachim (see below, text at note 276), is a prophecy which uses each of the twenty three letters of the alphabet to represent a century since the founding of Rome, so the world was to end in 1565. It placed the author's own time at the letter $\mathrm{v}$ and explained that it was written c.1204/5. It has been argued that it was perhaps written in Bamberg, and numerous manuscript versions survive, but a new edition is necessary before the early date can be accepted. See Sabine Schmolinksy, Der Apokalypsenkommentar des Alexander Minorita. Zur frühen Rezeption Joachims von Fiore in Deutschland (MGH Studien und Texte, 3) (Hanover, 1991), pp. 13-14 (and earlier bibliography ibid.), where Schmolinksy also notes that already in 1313 Henry of Harclay [chancellor of the University of Oxford and a key opponent of the Spirituals] recognized that it was not by Joachim.

${ }^{75}$ This section starts from and revises the useful outline provided in Pispisa, Gioacchino da Fiore e $i$ Cronisti Medievali, pp. 17-40.

${ }^{76}$ The Gesta was long attributed to "Benedict of Peterborough," but is now universally accepted as the work of Howden, following David Corner, "The Gesta Regis Henrici Secundi and Chronica of Roger, Parson of Howden," Bulletin of the Institute of Historical Research 56 (1983), 126-144.

${ }^{77}$ Following the opinion of the modernist theologian, Ernesto Buonaiuti, Gioacchino da Fiore: i tempi, la vita, il messaggio (Rome, 1931; repr. with an intro. by Antonio Crocco, Cosenza, 1984), p. 146, these authors were widely considered hostile to Joachim, who was himself a trenchant critic of the order he
} 
which is the earliest text, describes the encounter with Richard in Messina and Joachim's explanation of the biblical vision of John, identifying the seven-headed dragon of the Apocalypse as seven kings, five of whom had passed, one of whom was contemporary (Saladin) and one who was yet to appear. This last was the Antichrist, a Roman born pope, already fifteen, but who had not yet come to power. According to the undoubtedly anti-curial Howden, the prelates in attendance challenged Joachim's interpretation, but the king himself immediately identified the Antichrist as the then pope, "because he hated pope Clement [III]." Howden cited the writings of an antiquus as one of two further authorities to counter Joachim (in practice the antiquus was Adso of Montier en Der), but left the credibility of the prophecy hanging in the air: "the case, however, is still before the court" (tamen adbuc sub iudice lis est). ${ }^{78}$ As was frequently to occur, Joachim's reputation was being turned to political ends. Howden was using Joachim--himself critical of the contemporary Church--as a mechanism to condemn the curia and praise Richard, to whom the abbot was also reported as saying that God would give victory over his enemies, and that he would be glorified in eternity, as long as he persevered in the work he had started. ${ }^{79}$

The Gesta text illustrates both the polemical potential of Joachim's ideas and that he was already acknowledged as an exegete and a prophet, "spiritum habens propheticum" (a reference to the spiritus prophetiae of Revelation 19:10). ${ }^{80}$ By contrast, Ralph Niger, whose Chronica survive in two different versions, limited his account of Joachim's writing on the Antichrist to a few terse words: "a certain Cistercian monk [who], from almost illiterate, suddenly made intelligent, wrote on the Apocalypse ..."

had abandoned. Crocca points to Buonaiuti's judgement of the English chroniclers' account of the 1190 meeting with Richard as "artificioso, posticcio e leggendario," Ibid., p. xvii (citing Buonaiuti, p. 145). Buonaiuti believed them to be misrepresenting Joachim's teachings, but this was because he did not know of the Liber Figurarum which was only rediscovered later in the 1930s. Buonaiuti's assessment has since been identified as an overstatement, stemming from Coggeshall's irritated observation that Joachim--who had left the Cistercians to found his own order--was "of the Cistercian order, but not in the least obedient to them." See Radulfi de Coggeshall, Chronicon Anglicanum, ed. Josephus Stevenson (Rerum Britannicarum Medii Aevi scriptores, 66) (London, 1875), p. 67: “... ordinis Cisterciensis, sed Cisterciensibus minime subjectus." (A new edition and translation of Ralph's Chronicon Anglicanum is in preparation by Harriet Webster). See also Pispisa, Gioacchino da Fiore e i Cronisti Medievali, p. 28 and note.

${ }^{78}$ Roger of Howden/Hoveden, Chronica, ed. William Stubbs (Rerum Britannicarum Medii Aevi Scriptores, 51/3) (London, 1870), p. 79. The two other authorities are given on pp. 79-85 and 85-86.

${ }^{79}$ As argued by Pispisa, Gioacchino da Fiore e $i$ Cronisti Medievali, pp. 20-23. See Piero Zerbi, Papato, Impero e "respublica christiana" dal 1187 al 1198, 2nd edn (Milan, 1955; 1980), pp. 144-146, who notes the "deciso spirito autonomistico" of the English Crown (like the Sicilian) during the pontificate of Celestine. See now also John Doran, "A Lifetime of Service in the Roman Church," in Pope Celestine III (1191-1198). Diplomat and Pastor, eds. John Doran and Damian J. Smith (Farnham, 2008), pp. 31-80, p. 54.

80 This second point was particularly underlined by Bloomfield and Reeves, "The Penetration of Joachism into Northern Europe," pp. 776-777.

${ }^{81}$ Ralph Niger (Radulfi Nigri), Chronica: The Chronicles of Ralph Niger, ed. Robert Anstruther, (Publications of the Caxton Society 5) (London, 1851), pp. 96-97 (or with minor correction in Radulfus Niger Cronica. Eine englische Weltchronik des 12. Jabrbunderts, ed. Hanna Krause (Europäische Hochschulschriften) III/265 (Frankfurt am Main-Bern-New York, 1985), p. 286 : "quidam monachus Cisterciensis, a fere illiterato subito factus intelligens, scripsit super Apocalypsim ...”. Krause observes (ibid. p 
The passage was introduced apparently so that Niger could declare his preference for the more traditional commentary on the Apocalypse of Godefroid of Auxerre, the former Abbot of Clairvaux with whom Joachim had broken off relations in what became an acrimonious dispute when he left the Abbey of Corazzo to live the life of a hermit with Raniero da Ponza. ${ }^{82}$

Both Howden's later Chronicle, written after the failure of Richard's crusade (where Richard instead identifies the Antichrist as to be born in Antioch or Babylon), and the Chronicon of Ralph Coggeshall, written in the reign of King John, depended heavily on the Gesta. They adopted broadly similar techniques, using Joachim's reputation to embellish their accounts of the king and contemporary political affairs. ${ }^{83}$ But Coggeshall--a monk--expanded his narrative to include a detailed and wellinformed description of Joachim's interpretation of the Apocalypse and the concordances of the Old and New Testaments. His account places the death of the Antichrist at the end of the status of the sixth seal, to be followed immediately by the resurrection of the dead and the seventh age, the eternal glory of the saints, outside human history. ${ }^{84}$ Insistence on the first two ages--of the Father and of the Son--was characteristic of these chronicles. They ignored Joachim's status of the Holy Spirit, destined to produce a great spiritual regeneration on earth. ${ }^{85}$ Perhaps this was a reflection of their disquiet and pessimism, centred as it was on the imminence of the end of time. ${ }^{86}$

$242 *$ ), following Grundmann, that the reference to the sudden acquisition of learning may reflect Joachim's own self-description as 'homo agricola'. On Niger, see G. B. Flahiff, 'Ralph Niger: an introduction to his life and works', Mediaeval Studies 2 (1940), 104-26 and A. J. Duggan, 'Niger, Ralph (b. c.1140, d. in or before 1199?)', Oxford Dictionary of National Biography (Oxford, 2004) [http://www.oxforddnb.com/view/article/20192, accessed 9 Nov 2010] with earlier bibliography. ${ }^{82}$ As a response to Godefroid, Joachim wrote his Intelligentia Super Calathis, reasoning against using force to counter force, an argument addressed both to himself and to the Church in general, as noted by Valeria de Fraja, "Usi politici della profezia gioachimita," Annali dell'stituto storico italo-germanico di Trento 25 (1999), 375-400, 377. On his break with the Cistercians, and especially with Godefroid of Auxerre, see also Eadem, Oltre Citeaux, pp. 99-103. On Godefroid's charge that Joachim concealed the fact that he was born a Jew, see E. Randolph Daniel, "Abbot Joachim of Fiore and the Conversion of the Jews," in Friars and Jeres in the Middle Ages and Renaissance, ed. Steven J. McMichael and Susan E. Myers (Leiden, 2004), pp. 1-21.

${ }^{83}$ Buonaiuti, Gioacchino da Fiore: $i$ tempi, la vita, il messaggio, p. 146. Pispisa, Gioacchino da Fiore e $i$ Cronisti Medievali, p. 24.

${ }^{84}$ See also Krause, Radulfus Niger Cronica. Eine englische Weltchronik. The fullest work on Coggeshall and his sources (Guy N. Hartcher, 'Ralph of Coggeshall's Chronicon Anglicanum: An Investigative Analysis', PhD diss., The Catholic University of America, Wash. D.C., 1979), does not discuss his account of Joachim (I am grateful to Michael Staunton for drawing my attention to this dissertation; see also Staunton's own forthcoming study of Anglo-Norman historiography).

${ }^{85}$ As noted by Stanislao da Campagnola, L'angelo del sesto sigillo e l'alter Christus. Genesi e sviluppo di due temi francescani nei secoli XIII-XIV (Rome, 1971), p. 21. Joachim's De Septem sigillis was the object of detailed study in Julia Eva Wannenmacher, Hermeneutik der Heilsgeschichte. 'De septem sigillis' und die sieben Siegel im Werk Joachims von Fiore (Leiden, 2005).

${ }^{86}$ As suggested by Pispisa, Gioacchino da Fiore e $i$ Cronisti Medievali, p. 30. Bloomfield and Reeves, "The Penetration of Joachism into Northern Europe," p. 776, note Joachim's model of twos, based on the Old and New Testament, which lies at the basis of this interpretation. 
Coggeshall also describes an interview in Rome between Joachim and Adam, Cistercian Abbot of Perseigne (in the Saosnois), during which Joachim denied that he was a prophet, claiming instead that God had given him spiritual understanding to interpret Scripture. Despite the sensational tone of passages such as the prologue to the Liber de Concordia with which this chapter began, modern writers have widely identified this as an accurate reflection of Joachim's self-perception, avoiding the uncomfortable claims of prophecy. ${ }^{87}$ Coggeshall's Joachim then asserted--as in the Gesta account--that the Antichrist was already an adolescent in Rome, which he equated to Babylon. Unlike Howden, Coggeshall seems inclined to accept the validity of Joachim's account:

Our successors will be better able to judge what should be concluded about this man's claim, or rather opinion. But we are already witnessing that the rule of Babylon (typicum Babylonis) is acquiring the most dominion over the world, occupying the lands of Christians from day to day and spreading the disaster of error ... ${ }^{88}$

Coggeshall and Howden's writings were adopted and adapted by any number of later writers, including, importantly, the premonstratensian Robert of Auxerre (d. 1212), whose universal chronicle added an account of a visit to pope Urban III in Verona and was--in turn--to become a fundamental source for later writers. Following his predecessors, Robert described Joachim's approach to the first two states, placing the third outside history. He drew attention to Joachim's idea that the world was to end within two generations, which "according to him makes 60 years," when the Antichrist would come. Unlike Coggeshall, he also noted the suspicions that Joachim's ideas had aroused, judging it "safer not to discuss what we do not know and to leave judgement of things which are uncertain to us to posterity." ${ }^{89}$ Nonetheless, a few pages later, following Howden, he included Joachim's purported response to Philip and Richard's questioning at Messina in 1190, prophesying the disappointing outcome of their Crusade. ${ }^{90}$

Another early writer, who, like Coggeshall, points out how his predictions were already coming to pass, is Sicard, Bishop of Cremona in northern Italy (d. 1215). In his Chronicon, which shows a particular interest in the fate of the empire, Sicard wrote that Joachim:

\footnotetext{
${ }^{87}$ See for example, the discussion in Robert Moynihan, "The Development of the 'Pseudo-Joachim' Commentary ‘Super Hieremiam': New Manuscript Evidence,” in Mélanges de l'Ecole française de Rome. Moyen-Age, Temps Modernes 98 (1986), 109-142, 115.

${ }^{88}$ Coggeshall, Chronicon Anglicanum, ed. Stevenson, pp. 69-70. I am grateful to Christoph Egger for drawing my attention to the originality of Coggeshall's approach. See his forthcoming essay in a volume in memory of Marjorie Reeves.

${ }^{89}$ Robert of Auxerre (Roberti Canonici S. Mariani Autissiodorensis), Chronicon, ed. O. Holder-Egger, MGH SS 26 (Hanover, 1882), pp. 219-276, pp. 248-249.

${ }^{90}$ Ibid., p. 255. Pispisa, Gioacchino da Fiore e i Cronisti Medievali, pp. 36-40.
} 
had the spirit of prophesying and prophesied the death of emperor Henry and the future desolation of the kingdom of Sicily and the failure of the Roman empire, which is [now] most palpably declared, for the kingdom of Sicily is thoroughly disrupted and the empire is divided by schism. ${ }^{91}$

Sicard's work was to be picked up decades later by Salimbene de Adam, and this use of Joachim to interpret or undermine the imperial destiny was also to enjoy a great future. ${ }^{92}$

The prophetic version of Joachim and his view of the crisis of history was newsworthy, but chronicle writers after 1215 also allow us to trace something of the reaction to the condemnation of his ideas on the Trinity in the constitutions of Lateran IV. ${ }^{93}$ It was only very briefly mentioned in the few accounts of the Council itself, such as the fragmentary but more or less contemporary Annales Gotwicensis (Göttweig in the diocese of Passau) or an anonymous eyewitness account discovered in the 1960s, which does not seem to have circulated but provides lively detail on the mode of condemnation. ${ }^{94}$ After enthuastically accepting the articles of faith and the condemnation of all heretics, the assembled bishops were asked whether they also condemned the sentences of Joachim and Amalric: "against which they shouted out more strongly, 'we condemn'”. 95

Roger of Wendover (an English Benedictine monk, d. 1236) shows more detailed interest, referring to the unresolved nature of the debate about the Trinity (indeterminata altercatio) between the time of Alexander III (1159-1179) when Joachim wrote against the Lombard in his Libellus and the decision of 1215 which libellum ...

\footnotetext{
${ }^{91}$ Sicard of Cremona (Sicardi Episcopi Cremonensis), Chronica, ed. O. Holder-Egger, MGH SS 31 (Hanover, 1903), pp. 22-181, p. 175. I am grateful to Edward Coleman for drawing my attention to Sicard's imperial concern as a "connecting thread" in his work. There are also some parallels here with the anonymous Vita of Joachim. On the chronicle see Ettore Brocchieri, "Sicardo di Cremona e la sua opera letteraria," Annali della Biblioteca Governativa e Libreria Civica di Cremona XI (1958), Fascicle 1, and esp. pp. 91-92, for its use by Salimbene.

${ }^{92}$ See below text at note 245ff. This particular passage from Sicard was taken up by Salimbene, Cronica, ed. Scalia, p. 28. See also Pispisa, Gioacchino da Fiore e i Cronisti Medievali, p. 87.

${ }^{93}$ Bloomfield and Reeves, "The Penetration of Joachism into Northern Europe," p. 776, identify this emphasis on Joachim's understanding of scripture and the "crisis of history" as characteristic of the first phase of Joachim's reception outside Calabria.

94 “Annales Gotwicenses," ed. W. Wattenbach, MGH SS 9 (Hanover, 1851), pp. 600-604, 602. Stephan Kuttner and Antonio García Y García, "A New Eyewitness Account of the Fourth Lateran Council." Traditio 20 (1964), 115-178, at 127-128. Pixton, The German Episcopacy and the Implementation of the Decrees of the Fourth Lateran Council, pp. 269-70, argues that the Göttweig text is probably more or less contemporary and suggests that mention of Joachim's condemnation is found in no other German sources of this date. Kuttner and Garcia Y Garcia however, argued convincingly that the Eyewitness was also German.

${ }^{95}$ Kuttner and García Y García, 'New Eyewitness Account', p. 128: 'Postmodum dampnati sunt omnes heretici et reprobate quorumdam sententie, Ioachim videlicet et Emelrici Parisiensis. Quibus recitatis iterum quesitum est: 'An reprobatis sententias Ioachim et Emelrici?' At illi magis invalescebant clamando: 'Reprobamus'.
} 
dampnavit. ${ }^{96}$ Several authors also combined their reference to the condemnation with information which served to underline Joachim's desire for orthodoxy, or his prophetic ability. João de Deo, a Portuguese canon lawyer who taught in Bologna from 1229, wrote additions to Sicard's chronicle, and made the first real attempt to attenuate the condemnation of 1215 , noting with a lawyer's precision that neither Joachim himself nor his monastery were condemned. ${ }^{97}$ Other writers adopted a similarly conciliatory approach. The Cistercian Alberic of Trois Fontaines (d. c.1252), whose chronicle ends in 1241, blamed Joachim's condemnation on his "presumption," but distinguished his exegesis from that of his simpler contemporaries, and immediately pointed to the approval of the pope for his monasteries. ${ }^{98}$ The Dominican Vincent of Beauvais (d. 1264), who otherwise used the work of Robert of Auxerre for his account of Joachim's life, recorded the condemnation in his encyclopedic Speculum historiale (written in the late 1240s), but also reminded the reader that Joachim had sent his books to the pope for correction. ${ }^{99}$

As is manifest in the work of Howden, Coggeshall, or Sicard, chronicle accounts reflect the political position of the author towards secular and ecclesiastical authority, though of course their attitude need not be self-evident. In his extensive Chronica, Riccardo di San Germano (d. c.1243), a notary in the court of Frederick II from 1220, simply reports more or less verbatim the words of the Lateran constitution on the condemnation of the "book or treatise of Joachim against Peter Lombard, which he wrote on the unity or essence of the Trinity." 100 Riccardo had been at the Lateran Council in the company of his abbot, and his cursory comment has been interpreted

\footnotetext{
${ }^{96}$ Roger of Wendover, Liber qui dicitur Flores Historiarum (the Flower of History), ed. Henry G. Hewlett (Rerum Britannicarum Medii Aevi Scriptores, 84/I) (London, 1886), pp. 121-123.

${ }^{97}$ João de Deo (Iohannes de Deo), Chronica, ed. O. Holder-Egger, MGH SS 31 (Hanover, 1903), pp. 310-324, p. 323.

${ }^{98}$ Chronica albrici monachi trium fontium, a monacho novi monasterii Hoiensis interpolata, ed. P. Scheffert-Boichorst, MGH SS 23 (Hanover, 1874), pp. 631-950, p. 879: "Ioachim scriptor novus...qui multo aliter sentire videtur de adventu Antichristi, quam quidam nostri temporis, qui de die in diem simplicium corda sollicitare temere satis presumpserunt... scripsit idem Ioachim libellum quendam de Trinitate, in quo magistrum Petrum Lombardum in sententiis redarguere presumpsit, pro qua presumptione papa Innocentius in magno concilio postmodum Rome celebrato eundem libellum dampnavit, et sententiam magistri Petri, qui obscura videbatur, explanavit. Tamen cetera Ioachim opuscula et vitam eius religiosam et morum institutionem et eruditionem, quam in Florentino monasterio reliquerat idem Ioachim, papa Innocentius III. non improbavit, sed approbando commendavit."

${ }^{99}$ Vincent of Beauvais, Speculum historiale, ed. A. Koberger (Nuremberg, 1483) chapter 40. Online http://atilf.atilf.fr/bichard/. See also Pispisa, Gioacchino da Fiore e i Cronisti Medievali, pp. $42-43$ and the early 13th-century Chronicle of Saint Martin of Tours, Chronicon S. Martini Turonensi, ed. O. Holder-Egger, MGH SS 26 (Hanover, 1882) pp. 458-476, p. 467, typical of the "uncertainty which characterises the assessment of chroniclers between the condemnation by Innocent and the mid thirteenth century." (Pispisa, Gioacchino da Fiore e i Cronisti Medievali, p. 45). The idea is also found in Matthew Paris, Matthaei Parisiensis, monachi Sancti Albani, Chronica majora, ed. Henry Richards Luard, 7 vols. (Rerum Britannicarum Medii Aevi Scriptores, 57) (London, 1872-1884), vol. 2, p. 313.

100 "Chronica Ryccardi de Sancto Germano notarii," ed. Carlo Alberto Garufi, Rerum italicarum scriptores, second series 7/ii (Bologna, 1938), pp. 62, 73; Pispisa, Gioacchino da Fiore e i Cronisti Medievali, pp. 49-50.
} 
as an attempt to devalue the word and importance of Joachim, whose ideas were used in papal circles to oppose imperial activity. ${ }^{101}$ The passage seems, however, to have been written some time before the popes started using Joachim in their propaganda or Riccardo entered royal service, so it is not impossible that he was simply not interested in the details of Joachim's life and works.

Other writers, like Howden, used Joachite works to make more direct criticisms, if not always in openly or politically predictable directions. In his Annales Stadenses, which run to 1256, Albert of Stade, a German Benedictine who joined the usually pro-papal Franciscans in 1240, included a prophecy from the pseudo-Joachim Expositio Super Hieremiam (on which see below), in his account of king Louis IX's capture and ransom while on Crusade in the East, implying that France, allies of the papacy, would be defeated. But Albert combined this with a passage remarking on the same prophecy from a Commentary on the Apocalypse by an otherwise unidentified brother Alexander, presumably Alexander Minorita (on whom, again, see below), 'that the Church prays that what is said in revenge, shall pass in salvation'. ${ }^{102}$ Other writers, including the Muzio of Modena, author of the Ghibelline Annales Placentini (c.1295) and the English monk Bartholomew Cotton (d. 1298), author of a Historia Anglicana, made the French defeat more explicit. ${ }^{103}$ Albert, who died c.1264, also claimed that Joachim had prophesied that the Antichrist would be born in 1260, a position which echoes that of Gerardo di Borgo San Donnino, a friar destined to play a critical role in shaping Joachim's reputation in mid-century. ${ }^{104}$

\section{The Cistercians, the Florensians and the Development of Pseudo-Joachite Texts}

While chroniclers convey an approximate idea of Joachim's fama, it is the reproduction of his writings which most effectively exposes responses to his thinking. In the very early days, the propagators of Joachim's work were his close circle: Raniero da Ponza, his scribe Luca di Casamari (later Archbishop of Cosenza), and Giovanni, Abbot of Corazzo, together with his immediate monastic heirs, the Florensian monks, led by Abbot Matteo from 1202 to 1234. As we have seen, Raniero may, for example, have been responsible for the transmission of works to Navarre while Joachim was still alive and certainly used his ideas in his own writings. Later Luca also recorded his memories of the abbot. ${ }^{105}$

\footnotetext{
${ }^{101}$ Pispisa, Gioacchino da Fiore e $i$ Cronisti Medievali, p. 50.

102 Annales Stadenses, ed. I.M. Lappenberg, MGH SS 16 (Hanover, 1859) 271-379, 372: "Hiis auditis rumoribus, prophetiam abbatis Ioachim quidam reduxerunt ad memoriam, qui dixit, 'superabitur Francus, capietur pontifex summus, praevalebit imperans Alemannis'. Sed frater Alexander in expositione apokalypsis eandem prophetiam tangens, subicit sic: 'Sed ecclesia orat, ut quod dictum est in ultionem, transeat in salute." The MGH editor was unable to identify frater Alexander but see below note 147.

${ }^{103}$ Annales Placentini Gibellini, ed. G. H. Pertz, MGH SS 18 (Hanover, 1863), pp. 457-581, p. 516 s.a. 1266, citing the Super Hieremiam (see also below note 147). Bartholomaei de Cotton, monachi Norwicensis, "Historia Anglicana," ed. H.R. Luard, (Rerum Britannicarum Medii Aevi scriptores, 16) (London, 1859) pp. 239-240.

${ }^{104}$ Annales Stadenses, ed. Lappenberg, p. 351; Pispisa, Gioacchino da Fiore e i cronisti medievali, p. $53 \mathrm{n}$.

${ }^{105}$ Acta Sanctorum, Maius VII, Day 29: 93-4.
} 
In the years following Joachim's death, the Florensians were to be important editors and copiers of his work. They produced the early account of his life and a collection of miracles (c.1220) which underlined his orthodoxy and circulated well beyond Calabria. ${ }^{106}$ They were keen to emphasize Joachim's role as an ascetic monk and founder of their order, describing his prophecies as local and generally behind them by the early 13th century, though they also called him a new Jeremiah. ${ }^{107}$ They were probably responsible for compiling the Liber Figurarum, a collection of his figurae into one volume, creating what Reeves identified as a summary of the principal concepts of Joachim's thinking. ${ }^{108}$ The earliest extant manuscript (Oxford, Corpus Christi College, MS. 255A, fos. 4v-17v) was produced in the first decades of the 13th century at, or for, San Giovanni in Fiore. ${ }^{109}$ But the Florensians were not alone in undertaking this work. Joachim began his monastic career as a Cistercian and the connection stimulated interest in his writings in the order. Joachim himself records discussions of his thinking by the white monks, and manuscripts of his works were, as we have seen, copied in Cistercian houses, including Corazzo and Sambucina. ${ }^{110}$ Their mother-house at Fossanova may also have been involved.

Rewriting and revising was the norm, but a distinction is often drawn in this context between "Joachimists"--those who sought, as close followers of Joachim, to modify his teachings as little as possible, updating them only as necessary--and Joachites--those who accepted only the general lines of his teaching and modified them imaginatively but with the risk of distorting his original message. ${ }^{111}$ In the first category there is a famous copy of the so-called Letter-Testament of Joachim and the Liber de Concordia, now in the Corsiniana library in Rome, which includes minor changes perhaps made by the monks of Fiore to remove criticisms of the laity, on

\footnotetext{
${ }^{106}$ Grundmann, "Zür Biographie Joachims von Fiore und Rainers von Ponza," pp. 255-360; A.M. Adorisio, La "legenda" del santo di Fiore. Beati Ioachimi abbatis miracula (Rome, 1989). Salimbene de Adam demonstrates knowledge of the vita: Cronica, ed. Scalia, pp. 363-364.

${ }^{107}$ See de Fraja, "Usi politici," pp. 380-381.

${ }^{108}$ Marjorie Reeves and Beatrice Hirsch Reich, The Figurae of Joachim of Fiore (Oxford, 1972), p. 247, argued, for example, that the Figura showing the Dispositio novi ordinis, "seems to represent the nearest Joachim got to visualising the structure of society in the age of the Holy Ghost." Others have doubted that he would have provided details. See Töpfer, in the preface to the Italian edition, Il regno future della libertà, p. 12. The dating of the Liber is controversial: Selge argues that the figurae are genuine and the first sketches were done by Joachim in 1183, but that they were compiled by Abbot Matteo, his successor. See Kurt-Victor Selge, "L'origine delle opere di Gioacchino da Fiore in L'attesa della fine dei tempi nel medioevo," eds. Capitani and Miethke (as note 1) pp. 87-131, p. 128. The most recent volume on the Liber is Marco Rainini, Disegni dei tempi. Il "Liber Figurarum" e la teologia figurativa di Gioacchino da Fiore (Opere di Gioacchino da Fiore: testi e strumenti 18) (Rome, 2006).

${ }^{109}$ Valeria de Fraja, "Post combustionis infortunium," pp. 150-151 posits a copyist working at a neighboring Cistercian house, perhaps Sambucina, but see also below, note 112. The manuscript can be viewed online: http://image.ox.ac.uk/show? collection $=$ corpus\&manuscript $=255 \mathrm{a}$

${ }^{110}$ Edith Pasztor, "Gioacchino da Fiore, San Bernardo e il monachesimo cistercense," Clio, 20 (1984), 547-561; Sandra Zimdars-Swartz, Joachim of Fiore and the Cistercian order: A study of "De Vita Sancti Benedicti", in Simplicity and Ordinariness. Studies in Medieval Cistercian History, vol. 4, ed. J.R. Sommerfeldt (Kalamazoo, MI., 1980), 293-309.

${ }^{111}$ See note 12 above.
} 
whom their community increasingly relied. ${ }^{112}$ Much the most substantial means to the dissemination of Joachim's reputation and influence, nevertheless, is to be found in pseudo-Joachite literature which imitated Joachim in using prophetic commentaries to provide an understanding of contemporary history and a critique of the contemporary Church in the guise of authentic ancient prophecies. Like Joachim, these texts used the Old Testament books of Isaiah and Jeremiah and the New Testament Revelation of John. But whilst Joachim warned against the use of non-biblical prophecies (whether or not he was himself influenced by them), later writers exploited them widely, interpolating prophecies in the Prophetia ignota or Sibilla Samia, the Sibilla Erithea, and Verba Merlini, amongst others. ${ }^{13}$ The largest and most widely circulated of these pseudo-Joachim commentaries are the Super Hieremiam and Super Isaiam, which interpret the biblical books chapter by chapter, but also draw on extra-biblical prophecies. ${ }^{114}$ Shorter texts include the Expositio super Sibillis et Merlino, which purports to be a commentary on the non-biblical Sibylline prophecies. This has been attributed to a Cistercian-Florensian context, was composed in the 1240 s, and survives in two versions (in a total of nine manuscripts). Other texts attributed to Joachim include the Super decem plagas, a brief treatise on the plagues of Egypt interpreted by

${ }^{112}$ Rome, Biblioteca Corsiniana, MS 797. As argued by Fabio Troncarelli and E.B. Gioia, "Scrittura, Testo, Immagine in un manoscritto gioachimita," Scrittura e Civiltà 5 (1981), 149-186, 170. Troncarelli links this to two other manuscripts (BAV Barberini lat. 627; and Oxford, Corpus Christi College, 255A, the Liber Figurarum) on the basis of the same hand appearing in all three. He renews the point in Idem, "Nuove Reliquie dello 'scriptorium' di Fiore," in Atti del II Congresso Internazionale di Studi Gioachimiti (6-9 September 1984) (San Giovanni in Fiore, 1986), pp. 321-329, where he adds another: BAV, Chigi A VIII 231--the Expositio in Apocalypsim. The Corsiniana manuscript may not, however, have been produced at San Giovanni in Fiore. On the basis of analogous evidence for the production of Joachite texts, Antonio Maria Adorisio argues that it, together with BAV, Chigi A VIII. 231 and Oxford, Corpus Christi College, $255 \mathrm{~A}$, was produced at a scriptorium associated with the Cathedral of Cosenza, during the archiepiscopate of Luca, Joachim's former scribe (1203-1224). See Adorisio, Codici Latini calabresi, pp. 43-56 and Idem, "Momenti e aspetti della produzione libraria latina nella Calabria medievale," in Mestieri, Lavoro e Professioni nella Calabria Medievale: tecniche, organizzazioni, linguaggi. Atti dell'VIII Congresso storico Calabrese, Palmi (RC) (19-22 November 1987) (Messina, 1993), pp. 383403, pp. 392-398. Valeria de Fraja argues instead that Abbot Matteo may have commissioned these works: de Fraja, "Post infortunium," p. 150, and that Oxford, Corpus Christi College, 255A was perhaps produced at Sambucina. See above note 109.

${ }^{113}$ Matthias Kaup, "Pseudo-Joachim Reads a Heavenly Letter: Extrabiblical Prophecy in the Early Joachite Literature," in Gioacchino da Fiore tra Bernardo di Clairvaux e Innocenzo III (as above note 12), pp. 287-314, p. 288. On the Sibilla Erithea, see below, text at note 228 and Christian Jostmann, Sibilla Erithea Babilonica. Papsttum und Prophetie im 13. Jabrhundert, MGH SS 54 (Hanover, 2006) and also Alexander, "Diffusion of Byzantine Apocalypses," p. 84 (on Joachim's reasons for ignoring Byzantine sources such as the Sibilla Erithea).

${ }^{114}$ On the Super Hieremiam, see below. There is still no edition of the Super Isaiam prophetam beyond that printed in Venice, Lazzaro de Soardis, 1517, but de Fraja, "Usi politici," pp. 384-5 proposes that an early version may have been known to the Franciscans in the 1240s and be the text referred to in the circle of Hugh of Digne by Salimbene, and not the Super Hieremiam as long thought. Salimbene reports that a Dominican, Pietro di Puglia, lector in Naples, had asked Hugh how long Frederick II would live, leading to a discussion in which, according to the chronicler, both men quoted Joachim on Isaiah and referred to Frederick's life expectancy as 70 years, the figure found in the Super Isaiam, not the Super Hieremiam (where it is 60 years). Salimbene, Cronica, ed. Scalia, pp. 345-346. (See also below, text at note 299). 
reference to the tribulations of the Church, of which five manuscripts are known; a prophecy relating to the cities of the Veneto, the emperors, and the papacy, known by its incipit, In die illa elevabitur draco, which also survives in five manuscripts, and De regno siculo, on the destiny of Frederick II and his successors, now extant in just two manuscripts. ${ }^{115}$ Still other pseudo-Joachim texts are more overtly biblical, including the Super numerum hominis 666 on the apocalyptic number of the beast, and the De Oneribus Prophetarum, a commentary on extracts from the Old Testament which takes the biblical prophecies concerning the Near East and transposes them to the contemporary west (on which see below). Like many of these works, it is preceded by a letter allegedly from Joachim to the Emperor Henry VI, a conceit designed to lend authority to its claims and an indication of the value of Joachim's reputation. ${ }^{116}$

Of course, not all writings circulating in Joachite collections were Joachite. Ad memoriam eternorum, for example, a "heavenly letter" written $c .1241-3$, predicted the birth of a monster child, a small lion with the skin of a lynx (pardina), interpreted as a reference to Frederick II. ${ }^{117}$ As its modern editor, Matthias Kaup, makes clear, it is portrayed as a prophecy from God himself, found by a Cistercian monk written out on a linen altar corporal (the cloth for celebrating mass). Like Joachim, the author warns of the imminence of the End of Time, complains of the immorality of the clergy, and calls on them to reform. Kaup is convinced nonetheless, that it is not a Joachite prophecy. Nor was it produced in Joachite circles: instead, like numerous other such texts, it was simply incorporated into manuscript collections which transmitted Joachite works. ${ }^{118}$

Beyond preparing careful copies and pseudonymous versions of Joachim's writings, there is some evidence for oral transmission by the Florensians, through direct contact with other writers. The Cistercian Gebenon of Eberbach, on the river Neckar east of Heidelberg, records a meeting in 1217 with an unnamed Calabrian abbot who came to visit for two weeks and warned him that the Antichrist was about to be born (iam nasciturus). The ensuing discussion apparently prompted Gebenon to re-examine the works of a neighboring prophet, Hildegard of Bingen (d. 1179), and to produce an anthology of her writings on the Antichrist, in which he referred by name to Joachim, "who is also said to have had the spirit of prophecy" (qui etiam spiritum prophetiae habuisse dicitur) and which later incidentally contributed to anti-mendicant narratives of the friars as pseudo-prophets. ${ }^{119}$ That the monks of the Florensian order

\footnotetext{
${ }^{115}$ On the Super decem plagas see Matthias Kaup, who corrects previous attributions to Ranier of Ponza, in Gioacchino da Fiore, Commento a una prophetia ignota (Rome, 1999), p. 96 and notes. For the De regno siculo see ibid., p. 125n. For In die illa elevabitur draco see Leone Tondelli, "Profezia gioachimita del secolo XIII delle regioni venete," in Studi e documenti della Regia Deputazione di Storia patria. Sezione di Modena 4 (1940), pp. 1-9 and below, text at note 249.

${ }^{116}$ See for example Reeves, The Influence of Prophecy, p. 57. Canetti, L'invenzione della memoria, p. 342.

${ }^{117}$ Matthias Kaup, "Pseudo-Joachim Reads a Heavenly Letter" in Gioacchino da Fiore tra Bernardo di Clairvaux e Innocenzo III (as above note 12), pp. 287-314.

${ }^{118}$ Matthias Kaup, "Prophetie als Propagandamedium. Zu Funktion und Methode der Produktion und Exegese prophetischer Texte am Beispiel der Joachiten,” in Propaganda, Kommunikation und Öffentlichkeit (11.-16. Jahrbundert), ed. Karel Hruza (Vienna, 2003), pp. 81-87.

${ }^{119}$ La obra de Gebenón de Eberbach, ed. José Carlos Santos Paz (Millennio medievale, 46, Testi 12, La tradizione profetica, 2) (Florence, 2004), p. 97. Also discussed in Bloomfield and Reeves, “The
} 
were directly involved in the dissemination of Joachim's work is also attested by Salimbene de Adam's account of the arrival of manuscripts at the Franciscan convent of Pisa $c .1240$ (the moment which he also identifies as his own first encounter with Joachim's work). He tells us that a Florensian abbot, fearful that Frederick II would destroy his own, rural, monastery (probably Camaiore), brought them to Pisa for safekeeping. The presence of the books in the convent led the lector there, Ralph of Saxony (Rodulfus de Saxonia), to become a convinced Joachite (maximus Ioachita). ${ }^{120}$

Salimbene's version of events at Pisa, written in the 1280 s, also symbolizes another transition: from the 1240s the Florensians were increasingly to be replaced by the mendicant friars as transmitters of Joachim's ideas and Joachi[mi]sm. Engagement with his work was to have profound implications for the history of these orders, who also benefitted from close ties to the papacy. ${ }^{121}$

Outside the monastic-mendicant context, it was perhaps above all the papal curia which served as a hub for the dissemination of Joachim's ideas in the 13th century. ${ }^{122}$ As we have seen, Joachim himself encountered some of the popes of his lifetime and his work was certainly known to Innocent III. Cardinal Hugolino, later pope as Gregory IX (1227-41), wrote a remarkable lament on the death of Joachim's friend Raniero, and founded several Florensian houses, including one on family lands at Anagni which flourished during his pontificate. ${ }^{123}$ Valeria de Fraja has now, moreover, drawn attention to the career of a Florensian monk and lector, Giuseppe da Fiore, first documented in 1211, who was to become a papal notary in 1233, and is documented in the chancery from 1233 to $1235 .{ }^{124}$ In 1220 Giuseppe was entrusted, together with other monastics, with a preaching mission in northern Italy led by Dominic of Calaruega, founder of the Order of Preachers. He may also have encountered Hugolino during the Cardinal's legateship in the same region in the following year. Whether or not Giuseppe met the Cardinal-legate, his collaboration with Dominic currently amounts to the first documented encounter between the

Penetration of Joachism into Northern Europe,” p. 789 . See also Katherine Kerby-Fulton, 'Hildegard of Bingen and Anti-Mendicant Propaganda," in Traditio 43 (1987) 386-399. For the Calabrian visitor to Eberbach see de Fraja, "Una vocazione d'oltralpe," (see note 73 above); and Volkhard Huth, "Visionäre in Eberbach. Prophetische Verbindungslinien zwischen Süditalien und Mittelrhein," in Nassauische Annalen 114 (2003), 37-46.

${ }^{120}$ Salimbene, Cronica, ed. Scalia, p. 339. Lerner suggests that this may have taken place in 1247 when Frederick II passed through Tuscany en route to the Alps and the papal court at Lyons. See Robert E. Lerner, "Frederick II Alive, Aloft, and Allayed in Franciscan Joachite Eschatology," in The Use and Abuse of Eschatology in the Middle Ages, eds. Werner Verbeke, Daniel Verhelst, and Andries Welkenhuysen (Leuven, 1988), pp. 359-384, p. 359. For the identification of the Florensian abbot and house as Benedict of San Pietro di Camaiore, 25 kilometres from Pisa, see A. Callebaut, "Le Joachimite Benoit, abbé de Camajore et Fra Salimbene," Archioum Franciscanum Historicum 20 (1927), 219-222.

${ }^{121}$ See below, text at note $130 \mathrm{ff}$.

${ }^{122}$ For an analogous pattern of curial involvement in the dissemination of a work, see Christian Jostmann, Sibilla Erithea Babilonica. Papsttum und Prophetie im 13. Jabrbundert (MGH Schriften, 54) (Hanover, 2006). I am grateful to Anke von Holdenried for drawing my attention to this parallel. ${ }^{123}$ F. Caraffa, "I monasteri florensi del Lazio meridionale," in Storia e messaggio in Gioacchino da Fiore. Atti del I Convegno internazionale di Studi Gioachimiti (San Giovanni in Fiore, 1980), pp. 460-471. See also de Fraja, Oltre Cîteaux, pp. 174, 186.

${ }^{124}$ de Fraja “Usi politici,” p. 391. 
world of the Florensians and the mendicants, and may be when the friars first learned of Joachim's prophecy concerning two new orders. This may also have been the occasion of an encounter between Giuseppe da Fiore and Frederick II, who stopped near Bologna in October 1220 en route to Rome for his coronation and issued two important privileges for the monastery at Fiore. ${ }^{125}$

Giuseppe da Fiore's role as a papal notary is particularly significant because it coincides with what de Fraja has defined as a period which "theoriz[ed] the presence of the friars minor and preacher in the Church" along lines that coincide, in general terms at least, with the prophecies of Joachim. 1233 was the year of the Alleluia or "Great Devotion," an exuberant campaign of preaching and peacemaking in northern Italy led by a number of prominent preachers, including mendicant friars. It was celebrated by Gregory IX in two bulls issued in December of that year which describe the role of the friars in the story of salvation: they were the workers in the vineyard of the eleventh hour, immediately preceding the return of the owner of the vineyard and the payment of the workers (Matthew 20:6), in other words the Last Judgement. They had also preached against heretics, identified as those who prepared the way for the Antichrist (iter preparant Antichristo). ${ }^{126}$ In July of the following year, the bull of canonization of Dominic, Fons Sapientiae, developed this narrative in a distinctively monastic (as against clerical or episcopal) vein. The vision of four chariots coming out from two high mountains seen by the Old Testament prophet Zachariah (Zach. 6:1-8) was used to frame the history of the Church as a providential sequence of monastic movements or armies of the Lord. First came the chariot pulled by the red horses of the martyrs of the Early Church, followed by the black horses of the Benedictines who went to the "desert of the cloister" (claustrale desertum) and conquered the common life (communis vitae bonum), which had previously been lost. The third chariot, pulled by the white horses of the Cistercian and Florensian orders, gained the valleys full of wheat, singing hymns of praise. These had now been followed, at the eleventh hour, by a fourth chariot pulled by varied and strong horses, the armies of the friars preacher and friars minor, who arrived as dusk was falling, to act against the hostile multitude, when the vineyard was being destroyed by brambles, thorns, and little foxes. ${ }^{127}$ As well as the evident connection of Dominic's cult to the fight against heresy, it is not impossible that this was an allusion to Joachim's famous prophecy of

\footnotetext{
${ }^{125}$ Ibid., p. 393; Vicaire, Histoire de saint Dominique, pp. 247-248.

${ }^{126}$ See de Fraja "Usi politici," p. 396 and Grado G. Merlo, “'Militare per Cristo' contro gli eretici," in "Militia Christi" e crociati nei secoli xi-xiii (Milan, 1992), pp. 355-384, pp. 366-370; reprinted in Idem, Contro gli Eretici. La coercizione all'ortodossia prima dell'Inquisizione (Bologna, 1996), pp. 11-49, pp. $43-$ 44.

${ }^{127}$ Fons Sapientie, 3 July 1234: Bullarium ordinis fratrum praedicatorum, 8 vols, ed. Ripoll-Bremond (Rome, 1729-40) vol. 1, 67; Bullarum privilegiorum ac diplomatum Romanorum Pontificum amplissima collectio, ed. Caroli Cocquelines, 6 vols. (Rome, 1739-1762), 3 (Rome, 1740), pp. 282-283. A new edition is now in Humberti de Romanis Legendae Sancti Dominici, necnon materia praedicabilis pro festis Sancti Dominici et testimonia minora de eodem, adiectis miraculis rotomagensibus Sancti Dominici et Gregorii IX bulla canonizationis eiusdem, ed. Simon Tugwell (Corpus hagiographicum Sancti Dominici; Monumenta Ordinis fratrum praedicatorum historica, 30) (Rome, 2008), pp. 563-575.
} 
two new orders. ${ }^{128}$ For de Fraja, a clue to the authorship of the passage is the inclusion alongside the vast international order of the Cistercians of the tiny order of Florensians, numbering just ten houses in the south of Italy at this date. But if Giuseppe was indeed involved in drafting the bull, it is significant that, as she points out, he put his own order's role in the past alongside that of the Cistercians, rather than with the mendicants, the new "avant garde" in the history of salvation. ${ }^{129}$

\section{"Prophet of the Two Great Mendicant Orders"}

Joachim had written of the appearance, at the beginning of the third age, of a double monastic order of contemplatives and preachers who would be called to preach against the apocalyptic beast at the end of the sixth age, followed by the viri spirituales of the seventh. He may or may not have identified this function with his own order of Florensians: the point is appropriately obscure in his writings. ${ }^{130}$ Whether or not he did so, by the middle of the 13 th century, this role had been claimed by the mendicant orders of Franciscans and s, despite the loss of any distinction between contemplative and active orders that this entailed. The role assigned by Joachim served to reinforce the mendicants' conviction that they were destined to exercise a great role in salvation history. It may also have gained popularity among the friars as the criticisms of their activities by the secular clergy grew. ${ }^{131}$

There are various possible routes by which mendicant awareness of Joachim's thinking may have expanded, allowing this identification to emerge. Marco Rainini has recently drawn attention to the biblical allusion in Quoniam abundavit, a papal letter of 1217 , identifying the Dominicans as preachers in a long-established tradition, rising against the iniquity of pseudoprophets, as described in Matthew 24:11-14. ${ }^{132}$ Mira circa nos, announcing the canonization of Francis of Assisi in 1228 also refers to the new saint as one of the workers sent at the eleventh hour. ${ }^{133}$ Some writers have suggested that the "Alleluia," or great Devotion of 1233, which included mendicants, was still more directly Joachite. ${ }^{134}$ The most recent English-language writer on the

\footnotetext{
${ }^{128}$ Others have implied that it need not be: see the discussion in Canetti, L'invenzione della memoria, pp. 337-340.

${ }_{129}$ de Fraja "Usi politici," p. 398 note 72. She also suggests parallels with Joachim's Intelligentia super Calathis in the description of the Church losing its way under Constantine, but put right by the arrival of the Benedictines, ibid., p. 397.

130 de Fraja "Usi politici," p. 379 argues that he did not. Canetti, L'invenzione della memoria, p. 342 suggests that he probably did.

${ }^{131}$ See de Fraja, "Usi politici," p. 388.

${ }^{132}$ Marco Rainini, "I predicatori dei tempi ultimi. La rielaborazione di un tema escatologico nel costituirsi dell'identità profetica dell'Ordine domenicano," Cristianesimo nella storia 23 (2002), 307-343, 313-319. The biblical passage to which the bull refers is "And many false prophets shall rise, and shall deceive many. And because iniquity shall abound, the love of many shall wax cold. But he that shall endure unto the end, the same shall be saved. And this gospel of the kingdom shall be preached in all the world for a witness unto all nations; and then shall the end come."

${ }^{133}$ Bullarium Franciscanum Pontificum Romanorum, ed. G. C. Sbaraglia, 4 vols. (Rome, 1759-68, reprinted Assisi, 1983-4), vol. 1, pp. 98-99.

${ }^{134}$ See above, text at note 126 and also, for example, Leone Tondelli, "Introduzione e commento," vol. 1 of Il libro delle figure dell'Abate Gioachino da Fiore, eds. Leone Tondelli, Marjorie Reeves, and Beatrice Hirsch-Reich, 2 vols. (Turin, 1953), p. 194.
} 
Alleluia as a whole, Augustine Thompson, found no proof for a link with the anniversary of Christ's passion in $1233 .{ }^{135} \mathrm{He}$ also dismissed the evidence of the phrase Salimbene later used to describe the way the Alleluia was remembered--"a time of tranquillity and peace"--although it undoubtedly "parallel[s] Joachim's on the seventh age of the Church," arguing that it simply reflects Salimbene's own Joachite past. ${ }^{136}$ Any link can indeed be no more than conjecture, but we need not conclude that it is entirely unlikely, since Thompson's argument ultimately stems from the conviction that Joachim's works did not reach northern Italy until the 1240s, a view which can now be revised. ${ }^{137}$ Whether or not Salimbene was rewriting his own past, Joachim was [probably] in Verona to meet the pope in the 1180 s and as we have seen, his ideas had already reached beyond northern Italy, to Paris, by the 1190s, as well as to Sicard of Cremona before 1215. By 1216 the bishop of Lucca in Tuscany was being warned not to attack him and four years later, Giuseppe de Fiore was preaching with Dominic in northern Italy. The papal bulls Giuseppe later drafted may also have included those describing the events of 1233 . Whether or not the friars participating in the preaching and peacemaking of that year considered themselves members of the new orders prophesied by Joachim, it is not possible to omit northern Italy quite so categorically from the sphere of Joachite influence at this date.

There are other fragments which point to mendicant interest in apocalypticism in the 1230s. As well as the papal bull of 1234 which asserted the eschatological role of the friars as the workers of the last hour, the Dominican Master General Jordan of Saxony's Libellus de principiis Ordinis Praedicatorum (written either in 1218-19 and revised in 1233, or pulled together from earlier materials after the translation of Dominic's body in that year) also portrays the Dominicans as appearing by divine plan "in the perils of these last days." ${ }^{138}$ As Rainini observes, it may be significant that one of the few other extant works by Jordan is a Commentary on the Apocalypse. ${ }^{139}$ The Legenda of Dominic written by Petrus Ferrandi after the canonization, and approved in a revised version, probably by the General Chapter of 1238, again

\footnotetext{
${ }^{135}$ Augustine Thompson, Revival Preachers and Politics in Thirteenth-Century Italy. The Great Devotion of 1233 (Oxford, 1992), p. 23 note 62. On the Alleluia see also Daniel A. Brown, 'The Alleluia, a thirteenth-century peace movement', Archivum Fratrum Praedicatorum 81 (1988), 3-16; André Vauchez, 'Une campagne de pacification en Lombardie autour de 1233. L'action politique des Ordres Mendiants d'après la réforme des statuts communaux et les accords de paix', Mélanges de l'École Française de Rome 78 (1966), 519-549; Vito Fumagalli, 'In margine all'Alleluia del 1233', Bullettino dell'Istituto Storico Italiano per il Medio Evo 80 (1968), 257-272 and now also Marina Gazzini, 'In margine all'Alleluia del 1233: la Milizia di Gesù Cristo di Parma (1233-1261)', in Uno storico e un territorio. Vito Fumagalli e l'Emilia occidentale nel Medioevo. Atti del Convegno, Parma 11-12 ottobre 2002 (Bologna, 2005) pp. 235259.

${ }^{136}$ Salimbene, Cronica, ed. Scalia, p. 102: "Fuit autem Alleluia quoddam tempus quod sic in posterum dictum fuit, scilicet tempus quietis et pacis, quoad arma bellica omnino remota, iocunditatis et letitie, gaudii et exultationis, laudis et iubilationis." Thompson, Revival Preachers and Politics, p. 136 and note 1.

137 Thompson, Revival Preachers and Politics, p. 23 note 62.

${ }^{138}$ Rainini, "I predicatori dei tempi ultimi," 326; Simon Tugwell, "Notes on the life of St. Dominic," Archivum Fratrum Praedicatorum 68 (1998), pp. 5-33 dates Jordan's libellus to 1218/19 with revisions in 1233. Canetti, L'invenzione della memoria, pp. 158-173 prefers 1233.

${ }^{139}$ Rainini, "I predicatori dei tempi ultimi," p. 326.
} 
portrays the Dominicans as appearing at the eleventh hour, but no longer in the traditional vein as simply among those who preach. Ratherthey are now, more specifically, the specialists of preaching. ${ }^{140}$ Ferrandi's Legenda also makes Dominic the precursor of the Second coming, the star of the evening, the hour of dusk, equivalent to John the Baptist, star of the morning. ${ }^{141}$ Canetti, as we have seen, argues that this is simply part of a broader current of eschatological thinking, but it suggests at the very least that the friars were open to the sort of ideas espoused in the works of Joachim. ${ }^{142}$

The corpus of exegetical texts compiled c.1235/6 in the house of Saint Jacques in Paris under the supervision of Master Hugh of Saint-Cher (later the first Dominican Cardinal), illustrates a growing sense of an eschatological calling and, eventually, explicit Joachite knowledge among at least one group of friars. It includes a postil (commentary) on the Apocalypse (known as the Aser pinguis from its incipit) which takes up the idea from Hugh of Saint Victor that the seven trumpets of Revelation 811 are seven orders of preachers, making of the Dominicans the seventh trumpet. They would preach after the death of the Antichrist, to announce a period of peace and consolation. ${ }^{143}$ Lerner argues that this makes the anonymous Dominican compiler "the most chiliastic commentator on Revelation in the West since the patristic era," excepting only Joachim himself. Joachim is indeed quoted by name elsewhere in the text, though without adopting his exegetical method or allowing that anyone could know when the last times would come. ${ }^{144}$ Similar, if more attenuated ideas were taken up in a later postil, Vidit lacob, produced in the same Dominican circle in the early 1240s, this time with extensive passages taken from Joachim. ${ }^{145}$

The Franciscans in Naples have also been shown to have expressed interest in Joachim's thinking before the "translation" of his works to Pisa described by Salimbene. It may indeed have been in Naples that Friar John of Parma first

\footnotetext{
140 Ibid.

${ }^{141}$ Petrus Ferrandi, "Legenda S. Dominici," ed. Marie-Hyacinthe Laurent, in Monumenta Ordinis Prcedicatorum Historica 16 (Rome, 1935), pp. 209-260 also available ed. Franciscus van Ortroy, in "Pierre Ferrand O.P. et les premières biographes de S. Dominique fondateur de l'Ordre des Frères Prêcheurs," Analecta Bollandiana 30 (1911), pp. 27-87 or ed. Lorenzo Galmés and Vito T. Gómez, Santo Domingo de Guzmán Fuentes para su conocimiento (Madrid, 1987).

${ }^{142}$ Canetti, L'invenzione della memoria, p. 346.

${ }^{143}$ On the Aser pinguis, see also note 31 above. Robert Moynihan, "Joachim of Fiore and the Early Franciscans," pp. 108, 111, 112 (see note 32 above). Moynihan, quoting David M. Solomon, “The Sentence Commentary of Richard Fishacre and the Apocalypse Commentary of Hugh of St. Cher," Archivum fratrum praedicatorum 46 (1976), 367-377, 372, uses the evidence that Fishacre, who was in Oxford in the 1240s, knew Hugh's work to posit that there was "knowledge of Joachim in the Dominican order in England by the 1240s." Since Fishacre does not quote him, this is, unfortunately, unprovable. Some works attributed to Hugh have been seen as a team effort, with which Hugh had little involvement, see Lerner, "Poverty, Preaching, and Eschatology," pp. 182, 187. On Hugh more generally see Hugues de Saint-Cher (†1263). Bibliste et théologien, eds. Louis-Jacques Bataillon, Gilbert Dahan, and Pierre-Marie Gy (Bibliothèque d'histoire culturelle du Moyen Age) 1 (Turnhout, 2004) and below, text at note $153 \mathrm{ff}$.

${ }^{144}$ Lerner, "Poverty, Preaching, and Eschatology," p. 176.

${ }^{145}$ Ibid., pp. 158-181.
} 
encountered Joachism. ${ }^{146}$ But it was only in the 1240 s that the Dominicans and Franciscans both chose unequivocally to identify themselves as the viri spirituales who would herald the new age. The highly controversial pseudo-Joachim Super Hieremiam, one of the most influential prophecies of the late Middle Ages, illustrates the nature of this mendicant engagement with Joachim's thinking, by no means limited to the prophecy of the viri spirituales. ${ }^{147}$ The author or authors remain anonymous, and the text has been variously dated to 1241-3, 1248 or two phases (post 1241, but updated 1246-7). ${ }^{148}$ It is a commentary on the Old Testament book of the prophet Jeremiah, preceded, as customary, by a dedicatory letter purportedly addressed to Henry VI. It is laden with criticism of the corruption of the Roman Church and in particular of the Cardinals. It emphasizes the importance of the two orders of hermits and preachers and their role in liberating Christians from worldly wealth and defending the Church in the time of the three final tribulations: inflicted by the empire, saracens, and heretics. Until the mid-19th century it was believed to be by Joachim himself, substantially shaping his reputation. In the 1960s and 1970s it was instead debated as either Franciscan or Cistercian-Florensian in origins. Most writers now agree with Stephen Wessley that a first short version with some Franciscan references (which survives in six or eight manuscripts) was drafted in Cistercian-Florensian circles in Italy and that this was followed by longer, ever more Franciscan redactions, modified by marginal annotations which were incorporated into the text in later versions (seventeen manuscripts). ${ }^{149}$ The importance of the Super Hieremiam lies in its updating

${ }^{146}$ E. Randolph Daniel, "A Re-Examination of the Origins of Franciscan Joachitism," Speculum 43 (1968), 671-676, 674. See also Töpfer, Das kommende Reich, p. 110.

${ }^{147}$ Fiorella Simoni, "Il 'Super Hieremiam' e il gioachimismo francescano," Bullettino dell'Istituto italiano per il Medio Evo e Archivio Muratoriano 82 (1970), 13-46. See also Eadem, "Gli spirituali tra gioachimismo e responsabilità escatologica," in Chi erano gli spirituali. Atti del III Convegno internazionale (Assisi, 1975) (Società internazionale di Studi francescani) (Assisi, 1976), pp. 145-179. Examples of the reception of the Super hieremiam are to be found in Vincent of Beauvais (see below, text at note 163) and the Annales Placentini Gibellini, ed. Pertz, p. 516 which uses a single passage from the pseudo-Joachite Super Hieremiam to present Joachim as a visionary, prophetic of the fate of the Germans in southern Italy.

${ }^{148}$ Töpfer argued for 1241-3 (Das Kommende Reich, p. 109); Simoni linked it to the first explicit mention in 1248 (Simoni, "Il 'Super Hieremiam' e il gioachimismo francescano," p. 21, and Potestà argued for two phases: post 1241, but updated 1246-7 ("Il Super Hieremiam e il gioachimismo della dirigenza minoritica," pp. 888-889).

${ }^{149}$ S. E. Wessley, Joachim of Fiore and Monastic Reform (New York, 1990). Robert Moynihan argued that a core can be traced back to Joachim, but this has not been widely accepted: R Moynihan, "Joachim of Fiore and the Early Franciscans"; and Idem, "The Development of the Pseudo-Joachim Commentary Super Hieremiam: New Ms. Evidence," in Mélanges de l'École française de Rome. Moyen Age et temps modernes 90 (1986), 109-142. A list of manuscripts is available at www.centrostudigioachimiti.it, but no modern critical edition which might allow greater confidence about the sequence of composition has as yet been published. See also Potestà, "Il Super Hieremiam e il gioachimismo della dirigenza minoritica," p. 883. Stephen Wessley, "The Role of the Cistercians in the Writings of the Early Disciples of Joachim of Fiore," in Naissance et fonctionnement des réseaux monastiques et canoniaux: actes du Premier Colloque International du C.E.R.C.O.M. Saint-Etienne (16-18 September 1985) (Centre Européen de Recherches sur les Congrégations et Ordres Religieux) (Saint-Etienne, 1991), pp. 81-102. 
of Joachim's relatively specific message, relating it to contemporary events. ${ }^{150}$ But whereas Töpfer saw it as the work of "Franciscan extremists," Potestà argues that it may instead have reflected the views of prominent Franciscans and that it was prompted by the crisis surrounding the attack and capture in 1241, by the forces of the emperor, of prelates heading to a papally-convened council in Rome. ${ }^{151}$ After this traumatic episode, the Super Hieremiam was designed to provide an explanation for the failure of divine support for the leaders of the Church. In punishing the Cardinals, Frederick was carrying out divine will. But this was not anti-papal: unlike Joachim's original prophecies, according to the Super Hieremiam, in the third status the pope was to continue as the single vicar of Christ. ${ }^{152}$ The insistence on the role of the new orders and in particular the Franciscans may thus perhaps be linked to the election of John of Parma as minister general of the Franciscans in August 1247 and a sermon to the assembled Cardinals by a prominent Franciscan, Hugh of Digne, delivered no later than early 1248.

As a Franciscan and an eyewitness, Salimbene's semi-autobiographical chronicle provides a privileged perspective from which to observe the role of such Joachite thinking in his order and identifies further channels for the spread and influence of Joachim's ideas. He describes his own early, undifferentiated enthusiasm for Joachism and underscores the role of brother Hugh of Digne, reporting that Hugh had himself told him that he had received an invitation to preach to the curia from the pope, who had heard of his reputation as a great Joachite. ${ }^{153}$ He reports that Hugh was a close friend of John of Parma, the Franciscan Minister General (describing them both as "magni clerici et spirituales viri et maximi Ioachite"), as also of Bishop Robert Grosseteste of Lincoln and the English Franciscan Master, Adam Marsh. ${ }^{154}$ According to Salimbene, Hugh's cell in Hyères was frequented by notaries, judges, medics, and other men of letters who came on feast days to hear him discuss the doctrines of

\footnotetext{
150 Töpfer, Das Kommende Reich, pp. 108-124.

${ }^{151}$ See the colorful account by G. C. Macaulay, "The Capture of a General Council, 1241," The English Historical Review 21 (1891), 1-17.

152 Potestà, "Il Super Hieremiam e il gioachimismo della dirigenza minoritica," pp. 889-890. The author of the Super Hieremiam was strongly opposed to the crusade, preferring the idea of apocalyptic conversion. See E. Randolph Daniel, “Apocalyptic Conversion: The Joachite Alternative to the Crusades," Traditio 25 (1969), 128-154, reprinted in Joachim of Fiore in Christian Thought. Essays on the Influence of the Calabrian Abbot, ed. Delno C. West, 2 vols. (New York, 1975), vol. 2, pp. 301-328, p. 315.

${ }^{153}$ Salimbene Cronica, ed. Scalia, pp. 341-351. Salimbene must have invented much of the dialogue between Hugh and the Pope and Cardinals, if not the ensuing sermon: Potestà, "Il Super Hieremiam e il gioachimismo della dirigenza minoritica," pp. 886-887, notes the close ties between the latter and the Super Hieremiam, concluding that Salimbene's version should be taken at face value as Hugh's. Hugh of Digne's Joachism is not uncontroversial. See Fiorella Simoni, "Gli spirituali tra Gioachimismo e responsabilità escatologica," in Chi erano gli spirituali. Atti del III Convegno internazionale. Societa Internazionale di studi francescani (Assisi, 1976), pp.147-179, pp. 151-55.

${ }^{154}$ Salimbene, Cronica, ed. Scalia, pp. 351-353. The modern editor of Adam Marsh's letters suggests that he probably met Hugh during his stay at Lyons in 1245. See Letters of Adam Marsh, ed. Lawrence, vol. 1, p. xxx. On Salimbene's use of “magni clerici” to indicate his religious ideal, see Mariano d'Alatri, “Clerici' e 'magni clerici,"” in La Cronaca di Salimbene. Personaggi e tematiche (Rome, 1988) pp. 59-71, esp. pp. 67-69.
} 
Joachim, the mysteries of Scripture, and to foretell the future. ${ }^{155}$ Salimbene thus implies that laymen of learning were as interested in Joachim's interpretations as were men of the Church: his ideas were actively and eagerly discussed and debated.

It has been proposed that it was Hugh of Digne who sent a small book with a selection of Joachimite texts "from beyond the Alps" to Adam Marsh. Whether or not it came from Hugh, this was the booklet, referred to above, which Marsh then sent on to Bishop Robert Grosseteste, accompanied by a letter in which he demonstrated his belief in Joachim's prophetic powers:

[he] is thought, not without cause, to have been divinely inspired to understand the mysteries of prophecy, whether the dread days of immutable providence are at hand--the days of retribution so fearfully foretold by the prophets and even by the author of the prophets, against prelates and clergy, princes and peoples, on account of the monstrous swamp of their execrable and shameful misdeeds in these, alas, most wicked days; and that the time of God's stern judgement is beginning, in which the good is examined, evil reproved, and all things [are] ordered, following the divine command to "look up and lift up your heads, for your redemption is close at hand" [Luke 21:28]. ${ }^{156}$

This evocation of the resonance of Joachim's prophecies for at least one reformminded cleric was followed by Adam's request that Grosseteste have the booklet read in his room (cubiculum) with his secretaries present, have it copied, and then returned. Lending manuscripts to friends and patrons so that they could read and reproduce them was entirely typical though the suggestion that this should be done "in cubiculo" perhaps reflects a certain anxiety about Joachim's writings.

A north German Franciscan, known as Alexander Minorita (or Alexander of Bremen), records a visionary incident not unlike that experienced by Joachim, which enabled him to understand the Apocalypse. He seems already to have been writing a commentary on the text in the mid 1230s, while still a layman and probably before he knew Joachim's work. ${ }^{157}$ The most recent student of his Expositio in Apocalypsim, Sabine Schmolinsky, suggests that he then became aware of Joachite thinking c.1242 and revised his text, producing a second redaction which uses Joachim, perhaps as early as that year. ${ }^{158}$ His work, which survives in three different versions, is a collection of existing prophecies which suited his view of the future run of history. Thus he explicitly linked the new Jerusalem with the Dominicans and Franciscans:

\footnotetext{
${ }^{155}$ Salimbene, Cronica, ed. Scalia, p. 356.

${ }^{156}$ Adapted from Letters of Adam Marsh, ed. Lawrence, vol. 1, letter 43, pp. 119-120.

${ }^{157}$ Alexander Minorita, Expositio in Apocalypsim, ed. Alois Wachtel (MGH Quellen zur Geistesgeschichte des Mittelalters, 1) (Weimar, 1955). Schmolinsky, Der Apokalypsenkommentar des Alexander Minorita, pp. 121-123, points out that Albert of Stade cites a Frater Alexander, and Alexander himself makes extensive use of Albert's chronicle and mentions the Saxon Weltchronik, so he was clearly a Franciscan from Northern Germany. See also Reeves, The Influence of Prophecy, pp. 177-178. ${ }^{158}$ On the dating, see also Potestà, "Il Super Hieremiam,” p. 888 note 24.
} 
We indeed, according to what has been revealed to us, say that the Order of Friars Minor and Friars Preacher are in the beloved city. In this city one brother helps another so that it will be secure ... This city has the names of the twelve Apostles written into its foundations because the said friars characteristically imitate the life and teachings of the Apostles more than the works and words of other men. ${ }^{159}$

As well the prominence given to the major orders of mendicants, Alexander's work is typical of the various and elusive ways by which such texts can be related to Joachim. Schmolinsky notes, for example, that one group of manuscripts ascribes it to the abbot, while the commentary includes citations from Joachim's body of works, sometimes with the name. ${ }^{160}$ Alexander undoubtedly borrowed certain prophecies-on the nature of the beast, for example--but Schmolinsky nonetheless concludes that the extent of his knowledge of Joachim's work was narrowly limited (eng begrenzt). ${ }^{161}$ As perhaps for most of his contemporaries, it was acquired mainly through the Super Hieremiam, which he of course believed to be Joachim's own work. Indeed, he seems to be the first to cite it, whether c.1242 or 1248/9.

Modern historians have tended to concentrate on Franciscan responses to Joachim both because of their importance in developments among the Spirituals, and because the views of prominent Dominicans such as Thomas Aquinas or Cardinal Hugh of Saint-Cher were more hostile (the latter was appointed to a commission in the 1250s which condemned friar Gerardo da Borgo San Donnino, a keen Joachite). ${ }^{162}$ Yet as we have seen, the Order of Preachers had, like the Franciscans, begun to identify its calling in an eschatological sense, and knowledge of other aspects of Joachism is again suggested by the works of later Dominicans. The Speculum Historiale of friar Vincent of Beauvais, mentioned above, repeats the Super Hieremiam's account of an apocalyptic order, though no link with his own order of preachers is asserted. ${ }^{163}$ A Sienese friar, Ambrogio Sansedoni (1220-1286), a student of Albertus Magnus and classmate of Thomas Aquinas, wrote of the ages of the Church in his Sermones de Tempore, probably also composed in mid-century. In a vision of three ages he identified his own age as that of the last days, when God had sent either Dominic, servum suum, or, in another passage, the order of minors and preachers (ordines minorum et predicatorum) to proclaim the Gospel, replacing the earlier action of the

\footnotetext{
${ }^{159}$ Alexander Minorita, Expositio in Apocalypsim, ed. Wachtel, p. 454; Schmolinsky, Der Apokalypsenkommentar des Alexander Minorita, p. 36.

${ }^{160}$ Schmolinsky, Der Apokalypsenkommentar des Alexander Minorita, pp. 15, 66.

${ }^{161}$ Ibid., pp. 86, 123.

${ }^{162}$ A "questio," De prophetia, attributed to Hugh, portrays prophecy as a divine gift. See Jean-Pierre Torrell, Théorie de la prophétie et philosophie de la connaissance aux environs de 1230: la contribution d'Hugues de Saint-Cher: édition critique [of De Prophetia] avec introduction et commentaire (Spicilegium Sacrum Lovaniense: Études et Documents, 40) (Leuven, 1977).

${ }^{163}$ Reeves, The Influence of Prophecy, pp. 161-162. The passage is given in Rainini, "I predicatori dei tempi ultimi," pp. 335-336 note 99. Vincent of Beauvais, Speculum historiale, ed. A. Koberger (Nuremberg, 1483), p. xxxii, cap. 107. Also available from Douai MS 797 online at http://atilf.atilf.fr/bichard/.
} 
Prophets, Apostles, or Bishops. ${ }^{164}$ Still more direct is the work of friar Gerard de Frachet, author of the Vitae fratrum, a history of the Dominican brethren perhaps already begun before 1250 but later compiled at the behest of, and perhaps edited by, Humbert of Romans, the Dominican Master General (1254-63). ${ }^{165}$ Frachet seems to be the first Dominican to spell out the identification of his order with the new order of preachers prophesied by Joachim. ${ }^{166}$ His text, approved at the General Chapter of 1260, records, in a list of earlier authorities on preaching such as Augustine and Gregory the Great, and of prophets who had purportedly foreseen the coming of the order, including Hildegard of Bingen and the Sibyl:

Joachim too, abbot and founder of the Florensian order, [who] wrote of this order of preachers in many books and [other] places and, describing the order and habit, advised his brothers that when this order arose after his own death they should receive it devoutly. This they did, welcoming the brothers when first they came to them with the Cross and a procession. ${ }^{167}$

Humbert's own revised version of Dominic's Legenda, intended for exclusive use by the brothers and to replace Frachet, reiterates the eschatological theme, though it makes no direct reference to Joachim. ${ }^{168}$ But the story was again taken up in the German world by the Erfurt hagiographer Dietrich von Apolda, writing at the end of the century (1297). ${ }^{169}$ It was also adopted in the Franciscan Erfurt Chronicle, where a legend emerged that Joachim drew or commissioned pictures of the coming of the friars:

\footnotetext{
${ }^{164}$ Ambrogio Sansedoni, Sermones de Tempore, Siena, Biblioteca Comunale, MS T. IV 7 fol. 80r-v: "Postea in novo testamento per apostolos et postea per episcopos, sed modo quia iam est hora cene, misit servum suum, id est beatum Dominicum." Cited in Thompson, Revival Preachers and Politics, p. 11, who also notes that on fol. 82r Sansedoni replaces Dominic with "ordinem minorum et predicatorum."

${ }^{165}$ Simon Tugwell suggests Frachet may have begun writing before 1250. See "L'évolution des vitae fratrum. Résumé des conclusions provisoires," in L'Ordre des Prêcheurs et son histoire en France méridionale (Cahiers de Fanjeaux) 36 (2001), pp. 415-419, p. 415.

${ }^{166}$ Canetti, L'invenzione della memoria, p. 342; See also Schmolinsky, Der Apokalypsenkommentar des Alexander Minorita, p. 6. Canetti, L'invenzione della memoria, p. 344, denies that Humbert accepted anything more than a generic providentialist view of the prophecies of Joachim, citing the nonspecific nature of Frachet's account which he approved. Rainini, "I predicatori dei tempi ultimi," p. 337, draws attention to Humbert's use of a concordance "di sapore tipicamente gioachimita" in his Opusculum tripartitum, comparing the seven persecutions of the Church with those of the people of Israel and the seven heads of the beast in Apocalypse 17.

${ }^{167}$ Gerard of Frachet, Vitae fratrum Ordinis Praedicatorum necnon Cronica Ordinis ab anno MCCIII usque ad MCCLIV, eds. B. M. Reichert and J. J. Berthier (Monumenta Ordinis Fratrum Praedicatorum Historica, 1) (Leuven, 1896), I, ii, v, p. 13.

${ }^{168}$ Humbert of Roman, "Legenda sancti Dominici," ed. A. Walz (Monumenta Ordinis Fratrum

Praedicatorum Historica, 16, fascicle 2) (Rome, 1935) pp. 353-423, p. 369.

${ }^{169}$ Discussed in Reeves, The Influence of Prophecy, p. 162.
} 
this same abbot Joachim, before the creation of the Orders of Friars Minor and Friars Preacher, discussed these same orders in his treatise Super Hieremiam. He also named the orders and picked out the habit and showed them in wall paintings by the hand of a painter. ${ }^{170}$

This theme had also been elaborated in the Flores Temporum of an anonymous Swabian Franciscan writing in the early 1290s: "again, on the walls of his room he painted an image of the friars Minor, saying, these will soon come, girded by a rope, wearing sandals, most holy and powerful, enduring many things from the world, but lasting until the end of time." 171

The enthusiasm of these writers for a prophetic role which added lustre to their origins and purpose is undeniable. Mendicant responses to eschatological thinking were not all, however, so eager. In a widely disseminated work of instruction on the monastic and mystical life written sometime after c.1240, another Franciscan, David of Augsburg (d. 1272), companion of the great preacher Berthold of Regensburg (whom Salimbene described at length), complained that he was sick of revelations about the future or about secrets, which were believed to come from the Holy Spirit but really came from the spirit of error. ${ }^{172}$ David's lack of enthusiasm may not have been directed particularly against Joachism. Schmolinsky, for example, points out that neither the majority of the prophecies in his account, nor the sermons on the Last Judgement and the Antichrist of his companion (socius) Berthold, can be securely identified as Joachite. As we have seen, the reference to the coming of the Antichrist at the end of history was a standard part of Christian eschatology at this date and David and Berthold's material may well have come from other sources. ${ }^{173}$ Nonetheless David's frustration probably reflects a wider trend, one which also encompassed Joachism and grew in scale after the uncertainties of the middle of the century.

\section{Crisis}

The late 1250s and early 1260s mark what Gary Dickson has called "an unprecedented period of Joachist agitation." ${ }^{174}$ At the end of the 1240s a young Franciscan, Gerardo of Borgo San Donnino, and another friar, Bartolomeo Guisculus,

\footnotetext{
170 "Cronica minor Minoritae Erphordensis, continuatio I," in Monumenta Erphesfurtensia saec. xii, xiii, xiv, MGH SS rer. Germ, 42, ed. Oswald Holder-Egger (Hanover-Leipzig, 1899), pp. 671-685, pp. 679680.

171 "Flores temporum auctore fratre ordinis minorum," ed. O. Holder Egger, MGH SS 24 (Hanover, 1879) pp. 226-250, p. 239. See also Reeves, The Influence of Prophecy, pp. 72-73.

${ }_{172}$ David of Augsburg, De exterioris et interioris hominis compositione secundum triplicem statum incipientium, proficientium et perfectorum libri tres, ed. PP. Collegii S. Bonaventurae (Ad Claras Aquas [Quaracchi]: Ex Typographia Eiusdem Collegii, 1899), Book 3: De septem processibus religiosorum, p. 360. See Sabine Schmolinsky “.... iam multifariis vaticiniis iam usque ad fastidium repleti sumus...?” Deutsche Franziskaner des 13. Jahrhunderts im Umgang mit joachitischen Ideen," Wissenschaft und Weisheit. Zeitschrift für Augustinisch-Franziskanische Theologie und Philosophie in der Gegenwart 50 (1987), 164-175. Salimbene, Cronica, ed. Scalia, pp. 840-845.

${ }^{173}$ Schmolinsky, Der Apokalypsenkommentar des Alexander Minorita, pp. 5-6.

${ }^{174}$ Gary Dickson, "The Flagellants of 1260 and the Crusades," Journal of Medieval History 15 (1989), 227267, p. 252.
} 
sought to persuade Louis IX not to go on Crusade, predicting that it would be a failure--as was to prove the case. They told Salimbene that Joachim had foreseen this in his (pseudo) Super Hieremiam. In 1254 Gerardo, who had been appointed lector in Paris, circulated an Introductorius in Evangelium aeternum, in which he claimed that the Gospel had now lost its purpose and had been replaced by a new Eternal Gospel, which he identified as the corpus of the three major works of Joachim: the Liber de Concordia, the Expositio in Apocalypsim and the Psalterium decem chordarum, to which he furnished an introduction and commentary. ${ }^{175} \mathrm{He}$ identified the beginning of the age of the Spirit as 1260 and claimed that the Franciscans would be the pure men of the new Church. This was probably intended as a contribution to the growing controversy within the Franciscan order about the proper way to observe the Gospel and absolute poverty envisaged by Francis of Assisi. ${ }^{176}$ Undoubtedly it was a conscious rebellion against the authority of the Church and a tendentious interpretation of Joachim, who had not indicated a new text by his use of the term "Eternal Gospel." 177

Gerardo's work fell on fertile ground, though surely not as he had anticipated. The mendicant masters had been acquiring increasing prominence in the University of Paris since the late 1220 s, but periodically refused to participate in the corporate activities of their secular colleagues. When the latter went on strike following a violent attack on four secular students and their servant in the spring of 1253, the Dominican masters said they would join only if their participation did not affect their claim on one of their two chairs in Theology. ${ }^{178}$ The ensuing row fed attempts to throw the friars out of the University. Leading secular Masters were keen to challenge their privileged status, and Gerardo's work provided a perfect opportunity. They drew up a list of excerpts from the text to demonstrate its errors. ${ }^{179}$ Gerardo's original

\footnotetext{
${ }^{175}$ On Gerardo see Dieter Berg, Armut und Wissenschaft. Beiträge zur Geschichte des Studienwesens der Bettelorden im 13. Jabrhundert (Dusseldorf, 1977); Jürgen Miethke, "Papst, Ortsbischof und Universität in den Pariser Theologenprozessen des 13. Jahrhunderts," in Die Auseinandersetzungen an der Pariser Universität im 13. Jahrbundert, ed. A. Zimmerman (Miscellanea Mediaevalia, 10) (Berlin-New York, 1976); Edouard-Henri Wéber, "L'affaire de l'Evangile éternel et ses fructueux échos chez saint Bonaventure," in Lectionum varietates: Hommage à Paul Vignaux (1904-1987), eds. J. Jolivet, Z. Kaluza, and A. de Libera (Études de Philosophie medieval, 65) (Paris, 1991), pp. 67-83; and Roberto Lambertini, "Ende oder Vollendung. Interpretazioni eschatologiche del conflitto tra Scolari e Mendicanti alla metà del XIII secolo," in Ende und Vollendung: Eschatologische Perspektiven im Mittelalter, eds. Jan A. Aertsen and Martin Pickavé (Miscellanea Mediaevalia, 29) (Berlin, 2002), pp. 250-261.

${ }^{176}$ There is a vast literature on Franciscan poverty. As a starting point, see Malcolm Lambert, Franciscan Poverty: the Doctrine of the Absolute Poverty of Christ and the Apostles in the Franciscan Order, 1210-1323 (London, 1961); La povertà del secolo XII e Francesco d'Assisi. Atti del II Convegno di studi della Società internazionale di Studi Francescani (Assisi, 1975); and more recently David Burr, Olivi and Franciscan Poverty: the Origins of the Usus Pauper Controversy (Philadelphia, 1989) and Idem, The Spiritual Franciscans: from Protest to Persecution in the Century after Saint Francis (Pennsylvania, 2001). ${ }_{177}$ See the chapters in the present volume by Wannenmacher and Riedl, pp. 000, 000.

${ }^{178}$ Chartularium Universitatis Parisiensis, ed. H. Denifle, 4 vols (Paris, 1887-1897), vol. 1, no. 219, pp. 242-244 and notes.

${ }^{179}$ Wilhelm Preger, "Das Evangelium aeternum und Joachim von Floris," in Abhandlungen der historischen Klasse der Königlich-Bayerischen Akademie der Wissenschaften 12,3 (Munich, 1874), pp. 1-39, edition at pages 33-36. The fundamental article on the manuscript copies is H. Denifle, "Das 'Evangelium aeternum' und die Commission zu Anagni," in Archiv für Literatur-und Kirchen-Geschichte des Mittelalters, eds. Heinrich Denifle and Franz Ehrle, 1 (Berlin, 1885; repr. Graz, 1955), pp. 99-142.
} 
Introductorius does not survive, so it is not possible to establish the accuracy of the list, but amongst other errors, the Masters recorded the radical idea that not only was another gospel to follow the Gospel of Christ, but Christ's priesthood would also be superseded. ${ }^{180}$ They recognized that this was not Joachim's work since it referred to Frederick II's persecution of the Church, but they underlined the particular danger of its heresies. ${ }^{181}$ The list was unquestionably an attack aimed at the mendicants in general. It was translated into French and the secular masters, led by William of SaintAmour, promoted its message by means of sermons rallying the people of Paris against the friars. ${ }^{182}$ At first, pope Innocent IV sought to resolve this and other problems by removing mendicant privileges with the bull Etsi animarum (21 November 1254). But Innocent died just sixteen days later and on 22 December his successor, Alexander IV, a close ally of the mendicants, reversed his decision in the bull Nec insolitum, going on to reinforce mendicant privileges in the following spring in Quasi lignum vitae (14 April 1255). Meanwhile, in September 1254 Louis IX had returned to Paris from his failed crusade. He renewed his substantial support for the mendicant orders and, eventually, took the pope's line on the dispute.

Alexander IV acquired a copy of the Introductorius and the Paris list of errors and appointed a commission of three cardinals, including Hugh of Saint-Cher, to investigate. They met in July 1255 in Anagni, south of Rome (where the curia was in residence), having the original works of Joachim sent to them from Fiore as a point of reference. The protocol they issued first summarized the "errors and idiocies" (errores et fatuitates) of Gerardo, and then discussed Joachim's core teachings (thereby incidentally producing a summary of their reception in mid century), noting additions and corrections to his work made by Gerardo. In particular, they clarified Gerardo's notion that the Eternal Gospel was entrusted specifically to a new barefoot order (the

The references are from E. Benz, "Joachim-Studien II: Die Exzerptsätze der Pariser Professoren aus dem Evangelium Aeternum," in Zeitschrift für Kirchengeschichte 51 (1932), 415-455, Chartularium Universitatis Parisiensis, vol. 1, no. 243, pp. 272-276 and Christoph Anz, "Ein Rebell wider Willen? Joachim von Fiore und das Fortwirken seiner Geschichtstheologie bis zur Mitte des 13. Jahrhunderts," in Ordnung und Aufrubr im Mittelalter Historische und juristische Studien zur Rebellion, ed. Marie Theres Fögen (Frankfurt am Main, 1995), pp. 163-183.

180 "Quod evangelio Christis aliud evangelium succedet et ita per contrarium sacerdotio Christi aliud sacerdotium succedet." Chartularium Universitatis Parisiensis, vol. 1, no. 243, p. 272 and note 9.

Bernhard Töpfer identified Dresden, Sächsischen Landesbibliothek, A 121, as Gerardo's work on the basis of the glosses on the three books of Joachim which match those recorded by the protocol of the Commission of Anagni. It does not include Gerardo’s Liber introductorius. See Töpfer, "Eine

Handschrift des 'Evangelium aeternum' des Gerardino von Borgo San Donnino,” Zeitschrift für

Geschichtswissenschaft 7 (1960), 156-163.

${ }^{181}$ Benz, “Joachim-Studien II: Die Exzerptsätze der Pariser Professoren,” p. 425.

${ }^{182}$ See the discussion of William's work and the response of Thomas Aquinas in the chapter by Sven Grosse in the present volume. For William's sermons, see, The Opuscula of William of Saint-Amour. The Minor Works of 1255-56. ed. Andrew Traver (Beiträge zur Geschichte der Philosophie und Theologie des Mittelalters, Neue folge, 63) (Münster, 2003), pp. 53-81. Idem, “The Liber de Antichristo and the Failure of Joachite Expectations," Florensia, 14 (2001), 87-98 argues convincingly, following Lerner, that the Liber de Antichristo was written by William in the 1260s, celebrating the fact that the year 1260 had passed without effect (so proving that Joachim was a 'pseudo-prophet') and warning that the last days and the Antichrist were approaching, of which the hypocritical mendicant orders were the heralds. 
Franciscans) made up equally of the laity and the clergy. ${ }^{183}$ The Franciscan friar can thus be seen to have given his own order a unique role in the new status, going far beyond any earlier author's identification of the viri spirituales with the mendicants. ${ }^{184}$ The commission did not condemn Joachim himself, but it did identify errors in his authentic works, including, as Potestà has observed, his ideas about the replacing of the law of grace, the three status doctrine and the excessive praise of certain monks at the expense of the ordo clericalis. ${ }^{185}$ On 23 October 1255 Alexander IV wrote to the Bishop of Paris condemning both the Introductorius and the list of errors produced by the Paris Masters.

Meanwhile, pseudo-Joachite ideas were being exploited in other ways in the conflict between seculars and mendicants. Louis IX had tried to resolve the Parisian disputes first by summoning both sides to a gathering of several thousand clergy and then, on 1 March 1256, bringing together a smaller group to find a solution. Sometime later that spring, William of Saint-Amour, who had already been rashly preaching against Louis' adoption of mendicant-style dress and the presence of mendicants in the royal court, produced a pamphlet: De periculis novissimorum temporum. It was an apocalyptic text in which he identified all mendicants as the precursors of the Antichrist. ${ }^{186}$ It can have been no surprise to many Parisians when, on 27 June 1256, Louis had William imprisoned and expelled his associates from the University.

Gerardo too had been condemned, sentenced to life imprisonment and to having his work publicly destroyed, though it seems not all copies were immediately eliminated. Salimbene reports that, years later he was given a copy to inspect by the guardian of the Franciscan convent in Imola. A notary, he said, had copied it while in Rome with Brancaleone (degli Andalò, the Bolognese senator of the city in the 1250s). The notary had prized the book, but Salimbene claims to have judged it laughable and recommended that it be burnt, which it duly was. ${ }^{187}$

The storm unleashed by the events in Paris rumbled for decades, contributing importantly to anti-fraternal (anti-mendicant) satire and criticism. The potential damage to Joachim's own reputation as a prophet and exegete was also substantial. In the early 1260s the list of errors produced by the Paris masters, which equated

\footnotetext{
${ }^{183}$ Denifle, “Das ‘Evangelium aeternum’ und die Commission zu Anagni,” p. 102.

${ }^{184}$ For a fuller account of these events see the chapter by Sven Grosse in the present volume.

${ }^{185}$ Denifle, "Das ‘Evangelium aeternum,"” p. 115: “incredibilem exaltationem cuiusdam ordinis monachorum." Gian Luca Potestà, Angelo Clareno dai poveri eremiti ai fraticelli (Istituto storico Italiano per il Medio Evo: Nuovi studi storici, 8) (Rome, 1990), p. 100n.

${ }^{186}$ William of Saint-Amour, De periculis novissimorum temporum, ed. and trans. Guy Geltner (Dallas Medieval Texts and Translations, 8) (Paris-Leuven-Dudley, MA, 2008). Lerner suggests that the apocalypticism and citation of Joachim was intended either "to match quotation for quotation" or as a parody of Gerardo, which William abandoned in his later writing, such as the Liber de Antichristo. See Robert Lerner, "Refreshment of the Saints," p. 125. The idea of De periculis as a parody was earlier proposed by Brian Tierney, The Origins of Papal Infallibility, 1150-1350: A Study on the Concepts of Infallibility, Sovereignty and Tradition in the Middle Ages (Leiden, 1972) and is also pursued by Wendy Scase, Piers Plowman and the New Anticlericalism (Cambridge, 1989). More recently, Guy Geltner has argued that this is "overly dismissive" since eschatological apocalypticism "dominates William's other writings." See De periculis, ed. Geltner, p. 14.

${ }^{187}$ Salimbene, Cronica, ed. Scalia, p. 691.
} 
Joachim and Gerardo's work, together with the 1255 judgement, were included, for example, by a Dominican known as the Anonymous of Passau in an anthology bringing together writings on Jews, the Antichrist, and heretics. ${ }^{188}$ Joachim's teachings on the three status were further condemned at a provincial Synod in Arles in 1263. ${ }^{189}$ Although this was never taken up by the whole Church, Joachim's ideas were now circulating in unambiguously heretical contexts which were potentially far more damaging than the doctrinally restricted condemnation of 1215. And indeed, the echo of these events can again be found in contemporary chronicles such as those of the notary Alberto Milioli of Reggio (d. before 1265), the Saint Alban's Benedictine Matthew Paris (d. 1259), and the Prague Dominican Martinus Polonus (d. 1278). Alberto baldly reported the condemnation. ${ }^{190}$ Martinus was careful to convey the meaning of the papal judgement and to confute Gerardo of San Donnino's work, distinguishing it from Joachim's. By contrast, Matthew detailed the list of errors in his chronicle, attributing them to Joachim, whom he condemned, no doubt in part driven by his support for the secular masters and William of Saint-Amour. ${ }^{191}$ All three approaches were to be echoed by later writers. ${ }^{192}$

John of Parma, the Franciscan Minister General, was also profoundly affected by the scandal. In 1255, together with the Dominican Master General, Humbert of Romans, he had sent a letter to the members of their two orders which underlined that God, "the saviour of the world, had in these most recent days at the end of the world, stirred up [their] two orders." These were "two witnesses of Christ who, dressed in sackcloth, were now preaching and giving witness to the truth. These were those two bright stars which, according to the prophecy of the Sybil ... in the very last days cry out the name of the lamb for humility and voluntary poverty." ${ }^{193}$ This is an explicitly sibylline text with no overt citation of Joachim, though the ideas may derive from the Super Hieremiam. ${ }^{194}$ The identification of the two orders and association with Sibylline prophecy demonstrate at the very least the acceptability to both men of prophetic messages tied to an eschatological theme. ${ }^{195}$

\footnotetext{
${ }^{188}$ Alexander Patschovsky, Der Passauer Anonymus: ein Sammelwerk über Ketzer, Juden, Antichrist aus der Mitte des 13. Jabrbunderts (MGH Schriften, 22) (Stuttgart, 1968). For the author's Dominican identity, see Alexander Patschkovsky, "Passauer Anonymus," Verfasserlexikon 7 (Berlin-New York, 1989), cols. 320-324.

${ }^{189}$ On which, see the chapter in the present volume by Sven Grosse pp. 00-00.

${ }^{190}$ Alberto Milioli, "Liber de temporibus et aetatibus et cronica imperatorum," ed. O. Holder-Egger, MGH SS 31 (Hanover, 1903), pp. 336-462, cap. 261, p. 366. The use of Milioli by Salimbene or vice versa is still disputed.

${ }^{191}$ Paris, Chronica majora, ed. Luard, vol. 6, pp. 335-339.

${ }^{192}$ On whom see either Reeves, The Influence of Prophecy, pp. 71-95 or Pispisa, Gioacchino da Fiore e $i$ Cronisti Medievali, pp. 62-71.

${ }^{193}$ Litterae encyclicae magistrorum generalium Ordinis Praedicatorum ab anno 1233 usque ad annum 1376, ed. B-M. Reichert (Monumenta Ordinis Praedicatorum Historica, 5) (Rome, 1900), no. 8, pp. 25-31.

${ }^{194}$ Canetti, L'invenzione della memoria, p. 343 (and also p. 447) argues that attempts to identify explicitly Joachite themes in the letter is the product of qualche forzatura. Potestà, "Il Super Hieremiam e il gioachimismo della dirigenza minoritica," p. 892, argues that the letter "reveals a clear debt to the Super Hieremiam."

${ }^{195}$ On the Latin Sibylla Tiburtina see Anke Holdenried, The Sibyl and her Scribes. Manuscripts and Interpretation of the Latin Sibylla Tiburtina c.1050-1500 (Aldershot, 2006).
} 
Whether or not John was truly a Joachite, after just two years, at the General Chapter held in Rome in February 1257, he resigned his post, to be replaced by Bonaventure of Bagnoreggio. Five years later he was put on trial and his allegedly Joachite beliefs played an important role in his cross-examination. The trial is identified as the fourth of the tribulations of the order in the Historia septem tribulationum ordinis minorum of the Spiritual Franciscan, Angelo Clareno (d. 1337), an eschatological interpretation of the history of the Franciscan order, which would end with the dawning of a new era. ${ }^{196}$ Among the reasons for the persecution of John, Angelo identifies his criticisms of the observance of the rule in the order and his Joachism, but it is a very unusual form of Joachism. Angelo states that John and his followers believed that Joachim had had a Catholic and holy opinion of the Trinity of God, and that Innocent III and the 1215 decretal had not condemned him or his doctrine but only the libellus against Master Peter [Lombard], which was condemned because it was defamatory. Clareno went on to affirm Joachim's opinion of the sanctity of Peter's work, leading a recent commentator, Hanno Helbling, to observe that Angelo seems here to have been relying on another text, the Liber contra Lombardum, erroneously attributed to Joachim. ${ }^{197}$ There can, in practice, be no doubt that the Lateran Council and ensuing decretal had condemned Joachim's view of the Trinity, not just his defamation of Peter, so Clareno's account, like his source, is somewhat optimistic. His claim that the Joachite connection was used as an excuse for the investigation of John is equally obfuscated by the manner in which he presents it:

The brothers clearly moved from this second cause and reason and provoked brother Bonaventure to examine brother John and his companions in the faith, and excited the son against the father [Luke 12:53] and the beloved former disciple and subject against the careful master and pastor.

Clareno here implies a conflict between generations, and indeed, John had been Bonaventure's superior as Minister General for ten years to 1257 , but they had been coetaneous students in Paris, not master and disciple. ${ }^{198}$

\footnotetext{
${ }^{196}$ Angeli Clareni Opera II Historia Septem Tribulationum ordinis minore, ed. Orietta Rossini, intro. and comm. by Hanno Helbling (Fonti per la storia dell'Italia medievale: Rerum Italicarum Scriptores, 2) (Rome, 1999), Book 5, pp. 167-192. An English translation is now also available: Angelo Clareno, $A$ Chronicle or History of the Seven Tribulations of the Order of Brothers Minor, trans. David Burr and E. Randolph Daniel (St. Bonaventure, NY, 2005). The other main sources for the trial are "Chronica XXIV Generalium Ministorum Ordinis Fratrum Minorum" (which describes John as "per doctrinam Abbatis Ioachim in designatione finalium temporum deceptus") and the much briefer "Catalogus Generalium Ministrorum Ordinis Fratrum Minorum," in Analecta Franciscana 3 (Quaracchi, 1897), 350 and 698-699. The "Catalogus", ed. O. Holder-Egger is also in MGH SS 32 (Hanover, 1905-1913), 653677.

${ }^{197}$ Angeli Clareni Opera II, ed. Rossini, intro. and comm. Helbling, p. 175 note.

198 "Ex hac secunda causa et ratione apparenter moti sunt fratres et provocarunt fratrem Bonaventuram ad examinandum fratrem Iohannem et socios suos de fide, et commoverunt filium contra patrem [cf. Luke 12:53] et dilectum olim discipulum et subditum contra diligentem magistrum et pastorem." Angeli Clareni Opera II, ed. Rossini, p. 176.
} 
Clareno also reports that before John was tried, two of his companions, Gerardo and Leonardo, were first investigated and,

because they could not find anything by which to convict them of any heretical error, they called them to respond concerning the question of the divine essence, on account of which the little book of that abbot Joachim is censured (propter quam libellus ille abbatis Ioachim reprobatus est). ${ }^{199}$

As formulated by Clareno, their reply recalls the evasive and cautious emphasis on orthodoxy attributed by contemporaries to those facing the inquisition. ${ }^{200} \mathrm{He}$ has them assert,

that on that question they held to what the doctors of the Church and the holy councils determine and that Joachim did not hold or teach anything different to the teachings of the saints and the Church. ${ }^{201}$

The other Joachite link with John was supposedly two sermons written by his companions, the first of which praised the doctrine and person of Joachim without due measure (sine sale), presumably a reference to the work of Gerardo da Borgo San Donnino. The second cited the principle passages of the Bible in praise of the rule and of Francis, its distortion and the need for renewal, perhaps a reference to a work by Hugh of Digne (or John's companion, brother Leonardo). ${ }^{202}$ In his account of the interrogation of John himself--before both Bonaventure and the cardinal protector of the order, Giovanni Gaetano Orsini (later pope Nicholas III 1277-1280)--Clareno again sets out to undermine the legitimacy of the court, describing the shock and surprise the examination provoked and the anger and irreverence of the investigators, indignant when John raised his voice and declared "I believe in one God, Father Almighty" (Credo in unum Deum Patrem omnipotentem). ${ }^{203}$ The sentence John received, like his companions, was to perpetual imprisonment, modified after the intervention of Cardinal Ottobono Fieschi (later pope Hadrian V, 1276). He was allowed to choose his place of retirement, settling on Greccio (near Rieti), where another Spiritual Franciscan, Ubertino da Casale, was later to encounter him.

\section{"Proclaimer of 1260 as the Year of Crisis"}

\footnotetext{
${ }^{199}$ Ibid., p. 187.

${ }^{200}$ For one a near contemporary view of strategies before the inquisition see Bernard Gui, Practica officii inquisitionis heretice pravitatis, edited with facing page French translation as Manuel de l'Inquisiteur, ed. and trans. G. Mollat with G. Drioux, 2 vols. (Paris, 1926-7), vol. 1, pp. 64-76 and now also available in English as Bernard Gui, The Inquisitor's Guide: a medieval manual on heretics, ed. and trans. Janet Shirley (Welwyn Garden City, 2006), pp. 65-73.

${ }^{201}$ Angeli Clareni Opera II, ed. Rossini, p. 187.

202 Ibid., p. 177.

${ }^{203}$ Ibid., pp. 188-190 (the trial of John himself).
} 
Joachim himself never assigned a specific year to the time when the age of the Son would give way to the age of the Spirit. As we have seen, chroniclers such as Albert of Stade and the evangelising Gerardo da Borgo San Donnino had supplied the gap, identifying 1260 as the critical moment and associating Joachim with the date. It was undoubtedly a year marked by noteworthy events. In early September Florence was defeated by an unlikely Sienese coalition at the Battle of Montaperti. The ordo apostolorum led by Gerardo Segarelli of Parma, a lay movement focussed on poverty and preaching of the gospel, began that year and accrued remarkable success. ${ }^{204}$ That Segarelli's Apostles in particular may have been understood in a Joachite context is suggested by the strenuous denial by Salimbene, ever keen to protect the status of his own Franciscans (and to claim expertise on Joachim's writings):

But it is remarkable that Abbot Joachim seems to make no mention of these Apostles in his writings, as he did for the order of friars minor and friars preacher ... Which renders the fact of these Apostles very suspect to me and thoroughly to be condemned, because, if they were from God, abbot Joachim would never have passed them by in silence. $^{205}$

The autumn of 1260 also saw the appearance of the flagellants, or disciplinati, who undertook dramatic acts of physical penance in cities such as Modena, Reggio, and Parma. Again, the best source is Salimbene, who describes men of all social levels stripping naked and whipping themselves in public processions. Singing divine praise, they "walked ... in salvation" (ambulabant ... in salvatione). ${ }^{206}$ Salimbene himself was caught up in this "blessing and devotion" and claims that anyone who did not whip themselves "was considered worse than the devil ... and soon encountered some misfortune, either dying or falling gravely ill." He reports that Uberto Pelavicino, Lord of Cremona, was so alarmed that he had gibbets put along the banks of the river Po, threatening to hang any flagellant who crossed into his lands, a failure to recognize their virtue to which Salimbene later attributed his fall. ${ }^{207}$ Salimbene also records that Joachim's teaching "which divided the history of the world into three, should have begun [debebat inchoari] that year" and that the third status, of the Holy Spirit, "was said to have begun in that flagellation, which happened in $1260 \ldots$ when

\footnotetext{
${ }^{204}$ These apostolic brethren never obtained full recognition from Church authority. Segarelli himself was to be burnt in 1300; a second generation of the movement, led by Fra Dolcino of Novara and his wife Margherita, took up arms in 1304-5, but lasted only until 1307 when both were captured and burnt and more than 400 of their followers died. See Raniero Orioli, Venit perfidus heresiarcha. Il movimento apostolico-dolciniano dal 1260 al 1307 (Istituto storico italiano per il medio evo: Studi Storici, 193-196) (Rome, 1988) and Fra Dolcino. Nascita, vita e morte di un'eresia medievale, ed. Raniero Orioli (new edition: Milan, 2004).

${ }^{205}$ Salimbene, Cronica, ed. Scalia, p. 449-450: "Mirum est autem quod abbas Ioachim de istis Apostolis in scriptis suis nullam videtur facere mentionem, sicut facit de ordine fratrum minorum et fratrum predicatorum ... Per quod factum istorum Apostolorum omnino redditur michi suspectum et penitus contemnendum, quia, si ex Deo fuissent, abbas Ioachym nequaquam eos sub silentio preterisset.”

${ }^{206}$ Ibid., p. 703.

${ }^{207}$ Ibid., pp. 704 and 717-718.
} 
those who beat themselves called out 'with the voices of God, not man'" (dei voces et non hominis). ${ }^{208}$

The relationship between Joachism and these disciplinati remains unclear. Raoul Manselli maintained that Salimbene merely implied that the Joachites saw their own beliefs and prophecies confirmed in the revival. He does not say that the flagellants were Joachite or that Joachim's thinking gave birth to their movement. ${ }^{209}$ More recently, Gary Dickson has sought to nuance Manselli's views, pointing out the links made with 1260 by Albert of Stade and that other writers referred to this prophecy, including Alexander Minorita. ${ }^{210}$ Thus Dickson concludes that "the pilgrimage and mission of the disciplinati evidence the transmutation of Joachite speculation into popular apocalyptic anxiety centred upon the tribulations of the year 1260." 211 It is worth remembering, nonetheless, that the first request for holidays (ferias) accorded in Perugia in May 1260 was "because of the utility of the devotion which is done together in the said city and contado" (propter utilitatem divotionis que fit comuniter in predicta civitate et comitatu). ${ }^{212}$ Devotion (whether or not this was yet flagellation or linked to Joachism) was acknowledged as a useful communal activity, a solution perhaps to social, political and economic difficulties. And, as argued by Manselli, the explosion of the cult of the passion of Christ, and a desire to relive his suffering, may well have been more significant triggers. ${ }^{213}$

Salimbene tells us that the failure of 1260 to mark a great change was one of the factors in his own rejection of Joachism (accumulated to the shock of the early death of Frederick II ten years earlier). On being asked whether he had been a Joachite, he writes that he replied that it was true, but that "after Frederick died ... and the year 1260 had passed, I dropped that doctrine completely and decided only to believe in what I saw." ${ }^{114}$ Despite the emphatic quality of this statement, Salimbene had witnessed the way that the rise of the mendicants or Frederick II's behaviour matched what he knew of Joachim's prophecies. ${ }^{215} \mathrm{He}$ abandoned any belief in a Joachite, dated Apocalypse, but continued to use him as an authority (as we have seen, for example, on Segarelli's Apostles), and to cite his other prophecies approvingly, on the infant Frederick II, for example, a prophecy supposedly addressed to Frederick's

\footnotetext{
${ }^{208}$ Ibid., pp. 705 and 749.

${ }^{209}$ See Raoul Manselli, “L'anno 1260 fu anno gioachimitico?” in Il movimento dei disciplinati nel settimo centenario dal suo inizio. Atti del Convegno internazionale (25-28 September 1960) (Perugia, 1962), pp. 91-108; reprinted in Idem, Da Gioacchino da Fiore a Cristoforo Colombo, pp. 27-36 (as note 29 above). See also Arsenio Frugoni, who adopts the same view point as Manselli in "Sui flagellanti del 1260," Bullettino dell'Istituto storico italiano per il Medio Evo e Archivio Muratoriano 75 (1963), 211-237. This countered the earlier work of Antonino De Stefano, Federico II e le correnti spirituali del suo tempo (Rome, 1922; repr. Parma, 1981), pp. 103-104 and Tondelli “Introduzione e commento,” pp. 205-206 (see note 134 above).

${ }^{210}$ Dickson, "The Flagellants of 1260 and the Crusades," 253.

${ }^{211}$ Ibid., p. 258.

${ }^{212}$ Frugoni, "Sui flagellanti del 1260,” p. 212.

${ }^{213}$ On the link with the Passion, see Manselli, "L'anno $1260 \mathrm{fu}$ gioachimitico?” pp. 107-108, reprinted in Da Gioacchino da Fiore a Cristoforo Colombo, pp. 35-36.

${ }^{214}$ Salimbene, Cronica, ed. Scalia, p. 463.

${ }^{215}$ Pispisa, Gioacchino da Fiore e $i$ Cronisti Medievali, pp. 96-97.
} 
father Henry, which Salimbene specifies that he recorded as late as $1283 .{ }^{216}$ The chronicler thus seems to have maintained a careful distinction between those such as Hugh of Digne and his followers, who understood Joachim's spiritual message--the view he shared--and extremists such as Gerardo da Borgo San Donnino and his adherents who, in his view, had misread it. ${ }^{217}$

Salimbene's changes of tone and understanding after 1260 are important because he is undoubtedly the best source for our understanding of Joachism in the 13 th century. In more general terms, however, Reeves was surely right to argue that 1260 was not a difficult crisis for Joachism to weather: a revised calculation method identified the Passion rather than Christ's birth as the starting point, putting off the problem to $1290 .{ }^{218}$ Continuing evidence for Joachite thinking, moreover, is certainly not difficult to trace in the remaining forty years of the century.

\section{"Prophet of the Antichrist and interpreter of the seven-headed dragon"}

The Antichrist that was to appear before the coming of Christ at the end of time was not described with any precision in the Bible. Indeed the term "Antichrist" does not appear in the Book of Revelation and its symbolism left writers (and painters) free to imagine it as they saw fit. ${ }^{219}$ Joachim's ideas on this issue were summarized in a figura of the dragon described in Revelation 12:3: "And behold a great red dragon, having seven heads and ten horns and on his heads seven diadems." To Joachim this was Satan, the personification of evil. The seven heads corresponded to the seven persecutions of the Church and seven Antichrists. The first six were: Herod (representing the Jews), Nero (pagans), Constantine the Arian (heretics), Mahommed (muslims), Mesemotus (sons of Babylon), and finally Saladin, another Muslim, who had taken Jerusalem in 1187. The image of the dragon in the Liber Figurarum presents a wide space between the seventh head and a tail pointing upwards, which for Joachim corresponded to Gog, the final Antichrist. The tail alludes to the Gog who appears with Magog in the Apocalypse to launch the final

\footnotetext{
${ }^{216}$ Salimbene, Cronica, ed. Scalia, pp. 45-46; Pispisa, Gioacchino da Fiore e i Cronisti Medievali, p. 88. See also Delno C. West, "The Education of Salimbene of Parma: the Joachite Influence," in Prophecy and Millenarianism: Essays in Honour of Marjorie Reeves, ed. Ann Williams (Harlow, 1980), pp. 193-215, p. 205, and below, text at note 236 .

${ }^{217}$ As argued by Pispisa, Gioacchino da Fiore e i Cronisti Medievali, p. 97.

${ }^{218}$ Reeves, The Influence of Prophecy, p. 59; de Fraja "Usi politici," p. 387 notes that the Super Isaiam shows signs of revision to reflect this shift, including both the 1260 and 1290 dates at different points in the text. For similar millenarian rethinking after the failure of the apocalypse to materialise in 1000, see the two-part study by Richard Landes, "Millenarismus absconditus. L'historiographie augustinienne et le millénarisme du haut Moyen Age, jusqu'à l'An Mil," Le Moyen Age. Revue d'histoire et de philologie 98 (1992) pp. 355-377 and "Sur les traces du Millenium: la Via Negativa," Le Moyen Age. Revue d'histoire et de philologie 99 (1993) pp. 5-26, pp. 21-23. I am grateful to James Palmer for reminding me of Landes' approach.

${ }^{219}$ Wannenmacher, "Die Macht des Bösen” (as note 10 above). On artistic representations see Rosemary M. Wright, Art and Antichrist in Medieval Europe (Manchester, 1995). It is important to bear in mind that in the New Testament the term "Antichrist" is also used in a generic sense, for any power or person who was working against Christ. See for example 1 John 2:18: "Little children, it is the last time: and as ye have heard that antichrist shall come, even now are there many antichrists; whereby we know that it is the last time."
} 
offensive against the elect before the last judgement (Revelation 20:7). This final persecution of the Church was imminent, to be brought about by the last of the Antichrists, through whom the third status of the Spirit would begin. Joachim thus used his interpretation of the Bible to explain contemporary politics: in particular he drew parallels between the relationship of the Church and Empire with that of Judea and Egypt, and saw the submission of Israel to the Babylonians paralleled in the submission of the Church to the Imperial power. ${ }^{220} \mathrm{He}$ criticized churchmen as worldly, proud, and in need of humility, arguing that they should not spend so much energy defending the freedom of the Church. The empire itself was paralleled to the people of Babylon, but as a providential tool that would remove pride from the Church and allow it to find renewal and conversion, leading to true salvation. It was thus the apocalyptic beast, a necessity, sent by God to bring a proud and corrupt people back to the true way.

Joachim himself left the identity of the final Antichrist unspecified, but as we have already seen, it was a popular figure and readily adapted to suit contemporary contexts, whether or not always clearly Joachite. Most famously, the identification of the enemy as the Antichrist was taken up by writers observing or engaged in the controversy between the papacy and the Staufen emperor Frederick II (d. 1250), a conflict which first exploded in the late 1220s. ${ }^{221}$ According to the anonymous biographer of Gregory IX, in 1227, at the time of the first excommunication of the emperor, the pope preached a sermon on Saint Michael's Day comparing Frederick to the dragon defeated by the saint. ${ }^{222}$ Yet more spectacularly, in 1239, excommunicating the emperor for a second time, Gregory issued an encyclical, Ascendit de mari bestia, which identified "this beast Frederick, called emperor," with the beast of the Apocalypse arisen from the sea to destroy the world and the Catholic faith, and accused him of delighting in being called the prelude to the Antichrist (iste, qui gaudet se nominari preambulum Antichristi). ${ }^{223}$ It was the first of a series of encyclicals issued over the years 1239 to 1245 on the initiative of Raniero Capocci of Viterbo, CardinalDeacon of San Giorgio in Velabro (1244-1259), identifying Frederick II as either the precursor of the Antichrist or the Antichrist himself. ${ }^{224}$ The emperor and his court

${ }^{220}$ de Fraja, "Usi politici," p. 377.

${ }^{221}$ Andrea Sommerlechner, Stupor mundi? Kaiser Friedrich II. und die mittelalterliche Geschichtsschreibung (Publikationen des Historischen Instituts beim Österreichischen Kulturinstitut in Rom, I/11) (Vienna, 1999), pp. 220-230 discusses the transformation of Frederick into an "Exempelfigur".

${ }^{222}$ Giulia Barone, "La propaganda antiimperiale nell'Italia federiciana: l'azione degli Ordini Mendicanti," in Federico II e le città italiane, eds. Pierre Toubert and Agostino Paravicini Bagliani (Palermo, 1994), pp. 278-289, p. 287, citing “Vita Gregorii papae IX," ed. Ludovico Muratori in Rerum Italicarum Scriptores, 3/1 (Milan, 1723), pp. 575-587, p. 583. See also Le Liber Censuum de l'Église Romaine, eds. Paul Fabre and Louis Duchesne, 3 vols. (Paris, 1910-1952), vol. 2, pp. 18-36. ${ }^{223}$ Epistolae saec XIII e regestis pontificum romanorum selectae per G. H. Pertz, ed. C. Rodenberg, MGH Epp. Saec. XIII, 1 (Berlin, 1883), pp. 645-654, no. 750, p. 653 line 26; also in Historia diplomatica Frederici Secundi, 6 vols. in 11, ed. J.L.A. Huillard-Bréholles (Paris; repr. Turin, 1963) vol. 5/1 (1237-41), pp. 327-340 (the version sent to the Archbishop of Canterbury and his suffragans), p. 339.

${ }^{224}$ McGinn, Visions of the End, pp. 168-179 provides a brief outline of events, with illustrative texts. Hans Martin Schaller, "Das letzte Rundschreiben Gregors IX. gegen Friedrich II," in Festschrift Percy Ernst Schramm, 2 vols. (Wiesbaden, 1964), vol. 1, pp. 309-321, includes the text of Gregory's letter Vox in Rama of 1241, describing Frederick's cruelties and asking for advice on certain "capitula." See also 
responded by defending his orthodoxy, underlining that his hostility was to the person of the pope, not the Church, demanding that a council of churchmen gather so that the pope could be replaced and, of course, identifying him as the true Antichrist. ${ }^{225}$ A pro-imperial treatise identified Gregory's successor, Innocent IV, with the frightening, apocalyptic number of the beast, 666, and explained:

It should be known and firmly held by all Christ's faithful that since the Antichrist is said to be contrary to Christ, he will come in that state of life in which he will be most directly opposed to Christ and from which his fall will be the greatest .. . Hence it is necessary that Antichrist appear in the place of the Supreme Pontiff. ${ }^{226}$

The emperor himself also took measures to counter the activities of mendicants, some of whom were promulgating the papal message, ordering their removal from his lands already after the first condemnation of $1227-8 .{ }^{227}$ Although both pope and emperor were working within long-established rhetorical traditions--Pope Gregory VII had used comparable accusations in the eleventh century--it is no accident that the 1240 s were the period when pseudo-Joachite texts were produced which identified the

Peter Herde, "Ein Pamphlet der päpstlichen Kurie gegen Kaiser Friedrich II. von 1245/46 ('Eger cui lenia')," Deutsches Archiv 23 (1967), 468-538.

${ }^{225}$ See for example, Levate in circuitu, 20 April 1239, ed. L. Weiland (MGH Constitutiones et Acta publica imperatorum et regum, 2) (Hanover, 1896), no. 215, pp. 290-299, p. 297. Hans Martin Schaller, "Endzeit-Erwartung und Antichrist Vorstellungen in der Politik des 13. Jahrhunderts," originally in Festschrift H. Heimpel II (Göttingen, 1972), reprinted in Ideologie und Herrschaft im Mittelalter, ed. Max Kerner (Wege der Forschung, 530) (Darmstadt, 1982), pp. 303-331; updated and reprinted again in Hans Martin Schaller, Stauferzeit. Ausgewäblte Aufsätze (MGH Schriften, 38) (Hanover, 1993), pp. 25-52. Also discussed in Sommerlechner, Stupor Mundi?, passim, with substantial bibliographical information. Friedrich Graefe, Die Publizistik in der letzten Epoche Kaiser Friedrichs II. Ein Beitrag zur Geschichte der Jabre 1239-1250 (Heidelberger Abhandlungen zur mittleren und neueren Geschichte, 24) (Heidelberg, 1909) provides German translations of numerous tracts.

${ }^{226}$ Anonymous, "Libellus de Innocentio IV P.M. antichristo," in Fratris Arnoldi, De Correctione Ecclesie Epistola et De Innocentio IV P.M. Antichristo Libellus, ed. Eduardus Winkelmann (Berlin, 1865), pp. 2022, p. 20. See also B. McGinn, “Angel Pope and Papal Antichrist," Church History 47 (1978), 155-173, 160 (where he provides a translation of the relevant passage).

${ }^{227}$ See Anna Maria Voci, "Federico II imperatore e i Mendicanti: privilegi papali e propaganda antiimperiale," in Critica storica 22 (1985), 3-28, who contextualizes the close relationship between the papacy and the mendicants and the latters' activities against the emperors. Voci is criticized for an overemphasis on the hostility of the mendicants to the empire by Giulia Barone, who argues for a much more fluid situation in "La propaganda," p. 278. See also Eadem, "Federico II di Svevia e gli ordini mendicanti," in Mélanges de l'Ecole française de Rome. Moyen-Age, Temps Modernes 90 (1978), 607626. Cosimo Damiano Fonseca identifies different phases in the relations between emperor and mendicants, which were very poor from 1227-1229, improved after the treaty of San Germano and peace of Ceprano in 1229/30, but worsened again after 1239--the year when Friar Elias was deposed as Minister General and moved to the imperial court: see Cosimo Damiano Fonseca, "Federico II e gli Ordini Mendicanti," in Friedrich II. Tagung des Deutschen Historichen Instituts in Rom im Gedenkjahr 1994, eds. Arnold Esch and Norbert Kamp (Tübingen, 1996), pp. 163-181. Dieter Berg also outlines the effect on the order: see "L'impero degli Svevi e il gioachimismo francescano," in L'attesa della fine dei tempi nel Medioevo, eds. Capitani and Miethke (as note 1) pp. 133-167. 
mendicants as the two new orders charged with fighting the enemy of the Church. ${ }^{228}$ Early, short, versions of the Sibilla Erithea Babylonica, a popular and widely circulated prophecy in the late Middle Ages, were also produced, probably in the papal curia, in these years (1241 and 1249). ${ }^{229}$ The author began by using the framework of the Trojan wars, with the sibyl purportedly prophesying to the Greek troops, so as to arrange the religious, political and military conflicts of his time into a historical whole and then formulate prophecies concerning their outcomes. The main theme of this first part was the conflict between Greeks and Latins, taking in the problems of the failing Crusade and the Latin Empire of Constantinople, issues of particular concern to the papal curia. In part two, the history of ancient imperial Rome down to the conversion of Constantine was used to explore the fate of the "eagle" Frederick II, whose success, which would include retaking Constantinople (a genuine prophecy), would turn into defeat for his followers. The extent to which this was Joachite is open to debate: for Christian Jostmann, who has worked on it most recently, it was simply designed to drive the discussions within the papal curia, encouraging support for papal policies. It is undoubtedly based in part on the personal and political experience of its curial author, who chose the apocalyptic genre as an effective way to put across his message. And there are certainly Joachite overtones in aspects of the scheme it conveys, with an emphasis on the need for the purification of the Church. As a minimum, it seems to reflect continuing knowledge of Joachism in the curia in the years after Giuseppe di Fiore's activities there, knowledge underscored by the bulls issued in Gregory's name.

In 1245, Gregory's successor, Innocent IV, who had fled to Lyons, deposed Frederick, and the dispute acquired a yet more violent pitch. Mendicants still in the Regno were attacked and a number were executed. ${ }^{230}$ Both sides were more or less continuously at war, a state of affairs reflected in contemporary narratives. Alexander Minorita now changed his identification of the beast to Frederick II. His text refers to the defeat of the papal-Genoese fleet and capture of prelates on their way to Rome in 1241 (as mentioned by the Super Hieremiam), cites the Sibilla Erithea, the defeat of Frederick at Parma in 1248, and the capture of his son Enzo by the Bolognese in 1249. ${ }^{231}$ Poems were penned both by sides. ${ }^{232}$ Besides, once again, not all mendicants were necessarily anti-imperial. The provinces of the orders reacted differently: those in

\footnotetext{
${ }^{228}$ For de Fraja "Usi politici," p. 399, this change, which she dates to 1248-9, explains the attraction of Joachism to the mendicants.

${ }^{229}$ Jostmann, Sibilla Erithea Babilonica, p. 370, suggests that oral versions probably circulated first.

${ }^{230}$ See Barone, "La propaganda," pp. 278-289; Eadem, "Federico II di Svevia e gli ordini mendicanti," pp. 607-626; and Fonseca, "Federico II e gli Ordini Mendicanti," pp. 178-179, where he notes that in a letter (written in Greek) to the Byzantine Emperor, Frederick went so far as to identify the Friars Minor and Friars Preacher as the leaders of armies.

${ }^{231}$ For Schmolinsky, Der Apokalypsenkommentar des Alexander Minorita, p. 123, only here is the "Franciscan-Joachite influence" clearly evident. For the citation of the Sibilla Erithea, see Jostmann, Sibilla Erithea, pp. 71-74.

${ }^{232}$ Oswald Holder-Egger edited a substantial series of treatises and poems in, "Italienische Propheteien des 13. Jahrhunderts," Neues Archiv der Gesellschaft für ältere Deutsche Geschichtskunde zur Beförderung einer Gesamtausgabe der Quellen deutscher Geschichte des Mittelalters 15 (1890), 143-178; 30 (1905), 322386; and 33 (1908), 96-187.
} 
imperial lands north of the Alps became "enemies" of the emperor substantially later than in northern Italy and the Regno, which experienced Frederick's oppression much earlier. ${ }^{233}$ A treatise written from Frederick's viewpoint after 1245 was, for example, the work of a Swabian Dominican who sought imperial reform of the Church. ${ }^{234}$

Enjoying the long lens of hindsight, Salimbene is a good source, as ever, for the tradition of Frederick II as the Antichrist, making several references to the Frederickdragon parallel. ${ }^{235} \mathrm{He}$ takes this association of the emperor with evil back to Joachim himself: when Frederick was born, the emperor Henry, his father, purportedly asked Joachim about the destiny of his son. The abbot somewhat improbably replied that he would be "perverse and wicked ..." and, quoting the prophet Daniel, that he would "confound the world and trample on the saints of God ..." 236 The Franciscan also conveys with characteristic immediacy the traumatic impact of the death of Frederick in 1250 , before reaching the age of seventy prophesied for the Antichrist by Isaiah. He was persuaded that the emperor had died only when Innocent IV referred to it in a sermon in Ferrara nearly a year later because, as he put it, "as a Joachite, I expected and hoped that Frederick would do further evil. ${ }^{237}$ Nor was he alone in his disbelief. In San Gimignano, Tuscany, a goldsmith was so convinced that Frederick was still alive that he laid a notarized wager to that effect. ${ }^{238}$

Frederick's death contributed to Salimbene's loss of confidence in Joachite prophecies, yet as we have seen he continued to repeat a number of Joachim's concepts in his writing. ${ }^{239}$ So did many others: the number of prophecies and pseudoJoachim texts providing alternative dates for the beginning of the new status and naming new candidates for the role of the Antichrist only increased in the later 13th century. ${ }^{240}$ But Frederick's name did not disappear. The pseudo-Joachim Super Isaiam, for example (of which fifteen manuscripts survive), again presents a biting criticism of the Church and the avidity and pride of its prelates. This was to be followed by awful, but necessary persecutions, led above all by the Emperor, miseries which would lead, in Joachimite style, to purification. The text seems to have been written by a Franciscan in southern Italy in the 1250 s or 1260 s, but the emperor was nonetheless Frederick, the seventh head of the Apocalyptic dragon. ${ }^{241}$ And as late as $c .1300$ in an image of the beast, the seventh head, still labeled Frederick II, is much larger than the

\footnotetext{
${ }^{233}$ As observed by Andrea Sommerlechner, Stupor mundi?, pp. 50, 122-123.

${ }^{234}$ Ibid., p. 220; McGinn, Visions of the End, p. 170, citing Fratris Arnoldi, "De Correctione Ecclesie Epistola," who writes, for example, of "dominus F. serenissimus imperator" (ibid., p. 11). See also Graefe, Die Publizistik in der letzten Epoche Kaiser Friedrichs II., pp. 258-262.

${ }^{235}$ Salimbene, Cronica, ed. Scalia, pp. 551 (citing a prophecy ascribed to Michael Scot), 588, 661. See also Barone, "La propaganda," p. 287.

${ }^{236}$ Salimbene, Cronica, ed. Scalia, pp. 45-46. Discussed by Grundmann, "Federico II e gioacchino da

Fiore," in Idem, Ausgewäblte Aufsätze, vol. 2, p. 222.

${ }^{237}$ Salimbene, Cronica, ed. Scalia, p. 264.

${ }^{238}$ Töpfer, Das kommende Reich, p. 161.

${ }^{239}$ Salimbene, Cronica, ed. Scalia, p. 463. See also above text at note 216.

${ }^{240}$ Reeves, The Influence of Prophecy, pp. 49-52.

${ }^{241}$ Super Isaiam is variously dated from the 1240s (with later "stratifications," see de Fraja, "Usi politici," pp. 383-385) to 1260-66 (Lerner, "Frederick II, Alive, Aloft, and Allayed in Franciscan-Joachite Eschatology," pp. 377-379).
} 
other six, which are reduced to a subsidiary position, coming out of an opening in its neck. ${ }^{242}$ The associated text identifies Frederick as simply the forerunner of the Antichrist, but the image implies that Frederick himself was the Beast of the Apocalypse. ${ }^{243}$

A combination of Joachite prophecy and the sudden and unexpected nature of his death also contributed to the mythologizing of Frederick as the Messiah and saw him linked to the legend of the past and future emperor who would never die: “... whose death will be concealed and unrecognized and among the people will resound: 'he lives, he does not live," an idea which stemmed from the Sibylline tradition. ${ }^{244}$ Nonetheless, for others, Frederick's unexpected death encouraged the renewal of the Antichrist idea by combination with different, living figures.

The pseudo-Joachim Liber de Oneribus Prophetarum is one example of a new Franciscan propaganda. It is the first known prophetic text in which the theme of a mythologized Frederick is explicitly presented, imagined as a terrible anti-christian figure, then transformed into a messianic hero. ${ }^{245}$ De Fraja argues that this text is somewhat less polemical in tone since it places the beginning of the third status in the past, c.1200, suggesting that the necessary transformations of the Church had already occurred, and that it was already "on the way to perfection" thanks in particular to the interventions of the mendicants. ${ }^{246}$ Nonetheless, the text also assigns the attribute of supernatural evil to Frederick's successors. For Lerner, who follows the editor, Oswald Holder-Egger, in dating it to 1255-6, this was intended to reinforce Guelph resistance to the Ghibellines. ${ }^{247}$ Since 1260 had not yet come and Frederick was already dead, the writer sought another, last persecutor and purifier of the Church and thus named a third Frederick, designated as the heir to Belial (Frederick II). The identity of this third Frederick has been disputed, but may have been the Emperor's son, Frederick of Antioch, who died in $1258 .{ }^{248}$

Such associations of course gave the figura a new and particular political impulse, one repeated by other writers. The pseudo-Joachim Praemissiones, for example, a collection of figures and diagrams usually found together with the Super Isaiam, probably intended, as the name suggests, as an introduction to the text, and of which the earliest manuscript dates to 1255, identified the seventh Antichrist as Frederick II and the seventh age, also left unspecified by Joachim, as that of

\footnotetext{
${ }^{242}$ BAV MS. Vat. lat. 3822 c.5r, which also renames some of the other heads, so that the sequence reads: Herod, Nero, Constantine the Arian, Cosroes, Henry I (Emperor Henry IV), Saladin, and Frederick II, while the tail represents his heirs. For a reproduction, see Sommerlechner, Stupor Mundi?, fig. xiii.

${ }^{243}$ Hubert Houben, "Federico II come settima testa del drago apocalittico," in Il Ricordo del Futuro. Gioacchino da Fiore e il Gioachimismo attraverso la storia, ed. Fabio Troncarelli (Bari, 2006), pp. 75-79.

${ }^{244}$ See Jostmann, Sibilla Erithea, p. 300.

245 "Italienische Propheteien des 13. Jahrhunderts III," ed. Holder-Egger, Neues Archiv der Gesellschaft für ältere deutsche Geschichtskunden 33 (1908), 95-187, 139-187. See also Töpfer, Das Kommende Reich, pp. 132-136.

246 de Fraja, "Usi politici," p. 387.

${ }^{247}$ Lerner, "Frederick II, Alive, Aloft, and Allayed," p. 373 and note 46. Accrocca prefers 1256 in "Intorno ad alcuni recenti studi Gioachimiti," (as note 23) 172 and note; Canetti, L'invenzione della memoria, p. 342 note 70, dates it more broadly to $1250-60$.

${ }^{248}$ Töpfer, Das Kommende Reich, p. 133.
} 
persecution by Italian princes and heretics (principum ytalicorum et hereticorum), in other words, Frederick and his sons. Taking things a step further, the Franciscan Erfurt Chronicler included a prophecy concerning "the bastard Manfred," who would reign until the end of the kingdom and against whom would come a king from beyond the mountains, a lion of France for his audacity and sternness, who would defeat him and take the diadem from his head (a barely disguised reference to Charles of Anjou's defeat of Frederick's illegitimate son Manfred at the Battle of Benevento of 1266). ${ }^{249}$

The image of the dragon was also used in a brief pseudo-Joachim prophecy, In die illa elevabitur draco, dated by Tondelli to c.1264, during the papal interregnum. In a typically allusive and "post eventum" manner, it prophesied (amongst numerous elements perhaps referring to Manfred and Conradino and enigmatic references to the cities of Mantua, Brescia, and Verona), that "After Celestine, the proud pope would reign, after the proud the Catholic, after the Catholic the heretic, after the heretic nullus." Tondelli suggested that this was a reference to Celestine IV, followed by the "proud" pope Innocent IV, the "Catholic" Alexander IV and the "heretic" Urban IV (1261-64), the Frenchman who had called Charles of Anjou to Italy to face Manfred and against whom similar accusations were made in other texts. ${ }^{250}$ The nullus may have been meant to refer to 1260 or, still more radically, to the end of the papacy. ${ }^{251}$

The popes and the Staufen were not the only figures identified as the Antichrist or the beast. Salimbene, for example, reports a private conversation with Gerardo of Borgo San Donnino in which the friar related that the Antichrist was to be identified with the King of Castille. ${ }^{252}$ Other later prophecies included popes either as the Antichrist or as the pastor bonus/pastor angelicus, a term first recorded at the end of the century, in the turmoil of the conflicting views of the papacy triggered by the resignation of the holy hermit, Celestine V (1294) and election of the Roman Cardinal Benedetto Caetani as Boniface VIII (1294-1303). ${ }^{253}$ The idea of an angelic pope was perhaps made popular by the failure of the papacy to implement meaningful spiritual reform. ${ }^{254}$ Undoubtedly, it was a notion which found particular expression among the Spiritual Franciscans.

\footnotetext{
249 “Cronica minor Minoritae Erphordensis,” ed. Holder-Egger, p. 679 (as note 170).

${ }^{250}$ Leone Tondelli, "Profezia gioachimita," p. 7 (see note 115 above).

${ }^{251}$ Matthias Kaup, De prophetia ignota. Eine frühe Schrift Joachims von Fiore (MGH Studien und Texte, 19) (Hanover, 1998); Idem, Gioacchino da Fiore Commento a una prophetia ignota (Rome, 1999). For the text see Leone Tondelli, "Profezia gioachimita," pp. 5-6.

${ }^{252}$ Salimbene, Cronica, ed. Scalia, pp. 688-689.

${ }^{253}$ See Herbert Grundmann, "Die Papstprophetien des Mittelalters,” Archiv für Kulturgeschichte 19 (1928), 77-138, who pointed out their dependence on Byzantine Leo oracles, but transforming the Greek emperors into Roman popes. See Robert E. Lerner, "On the Origins of the Earliest Latin Pope Prophecies,” in Fälschungen im Mittelalter, 5 (MGH Schriften 33/V) (Hanover, 1988), pp. 611-635. Lerner argues convincingly that the earliest version was produced outside spiritual Franciscan circles by an Englishman, "Rabanus Anglicus," who may be the Rabanus placed between Donatus the Grammarian and Joachim in Dante's Paradiso 12.139 (see also below).

${ }^{254}$ As first argued by Herbert Grundmann and more recently by Bernard McGinn: McGinn, “Angel Pope and Papal Antichrist," pp. 158-161.
} 


\section{Joachim and Spiritual Franciscans}

Members of the order of friars minor who sought to reform their lives according to what they identified as its original forma vitae centred on the figure of Francis of Assisi and poverty, found in Joachim an advocate for their own sense of destiny as the true viri spirituales of the new era. Brother Peter of John, known as Olivi (c.1246-1298), was an important and influential figure in this process, adapting substantial elements of Joachim's concepts of history to his own experience. As David Burr has shown, his approach was closely related to Joachim's, though with significant differences, one of which was his use of status to refer to phases in both his patterns of three and seven. ${ }^{255}$ Olivi divided history into three ages: of the Father (from the Creation to Christ), the Son (Christ to Saint Francis), and the Holy Spirit (Francis to the Last Judgement). At the same time, he divided history into two blocks, each with seven subdivisions. The first began with Creation and ended with Christ. ${ }^{256}$ The second would run from Christ to the end of everything (Eschaton). Thus the first age, of the Father, corresponded to the first seven periods. The second set of seven were further specified as: the primitive Church, the martyrs, the teachers, the anchorites, and in fifth place, the period from the beginning of the empire of the Franks, when the Church gained power and wealth but "at the cost of rigour." In his Lectura super Apocalipsim, Olivi made it clear that these periods were linked to each other, so that each prepared the next. ${ }^{257} \mathrm{He}$ placed his own time at the end of the fifth period (condescensio), when the Church was secure, rich, and powerful but the price was a weakening of its standards. ${ }^{258}$ The end of this period, nonetheless, also marked the beginning of the sixth, which in this scheme was begun by Francis of Assisi and was denoted by a return to the apostolic lifestyle. At the time of writing, however, Peter saw the carnal Church as preparing to launch an assault led by a first, mystic (hidden) Antichrist. Like earlier Joachites, he considered himself to be living in a time of trouble which would eventually be overcome. The attack of the mystic Antichrist would reduce "the true followers of Christ to a persecuted remnant," but their persecutors would in turn be destroyed by a further attack, an invasion of ten kings who, while intending to destroy Christianity, would instead demolish the carnal Church. There would then follow the persecution of the second, great Antichrist, who would in turn be destroyed by Christ. The Jews would convert, Satan would be bound, and the sixth period would give way to the seventh, a time of peace and

\footnotetext{
${ }^{255}$ See David Burr, “Olivi’s Apocalyptic Timetable," 237-260 (as note 7 above). See also David Burr, "Apokalyptische Erwartung und die Entstehung der Usus-Pauper-Kontroverse," Wissenschaft und Weisheit. Zeitschrift für Augustinisch-Franziskanische Theologie und Philosophie in der Gegenweart 47 (1984), 84-89.

${ }^{256}$ This is based on his commentary on Revelation, which when Burr was writing (Burr, "Olivi's Apocalyptic Timetable," p. 238 note 4) was to be published by Warren Lewis who wrote his doctoral dissertation on Olivi: "Peter John Olivi: Prophet of the Year 2000," (Ph.D. diss., Tubingen, 1972). ${ }^{257}$ As noted by R. Manselli, "Il tempo escatologico (secoli xii-xiii)," in Le temps chrétien de la fin de l'antiquité au Moyen Âge, IIIe-XIIIe siècles (9-12 March 1981) (Colloques Internationaux du Centre National de la Recherche Scientifique, 604) (Paris, 1984), pp. 541-549, p. 548; reprinted in Idem, Da Gioacchino da Fiore a Cristoforo Colombo," intro. and ed. Paolo Vian, pp. 681-692, p. 692 (as note 29 above).

${ }^{258}$ Burr, "Apokalytpische Erwartung," p. 84.
} 
contemplation. The end would come as piety again declined, Satan was unbound, and the persecution of Gog would lead to divine intervention in the form of the Last Judgement. ${ }^{259}$

Olivi never acquired the title of master and was condemned both in life and posthumously: his treatment was to be identified by Angelo Clareno as the fifth tribulation, following that of John of Parma. Even so he acquired a wide following and his work was to be enormously powerful. At the end of his life, his Lectura super Apocalipsim relaunched Joachim's teachings in contemporary terms, from which the Franciscan sense of history is clear. Starting from the Bonaventuran notion of the responsibility of the Franciscan order in the Church, in face of the decadence of his time--which not even the pastor angelicus, pope Celestine V (1293-4), was able to overcome--the providential mission of the order was that prophesied in the Apocalypse: to constitute the strength of the Church of the elect. Olivi's criticism of wealth (as against the virtue of poverty) was not restricted to churchmen, but in his Quaestio de altissima paupertate, he underscored the corruption of the inhabitants of wealthy abbeys and well-endowed churches. ${ }^{260} \mathrm{He}$ saw his own period as one of new spiritual opportunities and also of new dangers. The "godly can expect not only to attain greater levels of evangelical piety and understanding but to be persecuted for their trouble." ${ }^{261}$ The autobiographical element--as a Spiritual Franciscan disputing with his own order and beyond--is unmistakable. He saw aspects of Aristotelianism and attacks on true Franciscan poverty as "the error of Antichrist." The resignation of Celestine V in 1294 was a test which had revealed the true spiritual decay of the Church. So it was necessary to prepare for the Last Times. In a letter to the sons of Charles II of Anjou, he wrote of the hour of trial, perhaps the supreme test. ${ }^{262}$ Although he was cautious (the failure of early prophecies correctly to predict the millenium and the fate of Gerardo da Borgo San Donnino would have been warning of the need), he also went on to suggest some possible dates for the unfolding of the end, placing the completion of the fifth period at circa $1301 .^{263}$

Olivi quoted frequently from Joachim and, as Manselli underlined, knew his work perfectly, but his eschatological periodicity was christological, not trinitarian. ${ }^{264}$ For Joachim, Christ and the Church were moments in the operation of the expression of the Trinity. For Olivi, Christ is at the centre of history and the Church is principally and in substance Christ-based. The moment of the spirit is an interior transformation more than an institutional renewal. The spiritual Church for Joachim is the conclusive moment of detachment from the earthly world, to enter eternity.

\footnotetext{
${ }^{259}$ Burr, "Olivi’s Apocalyptic Timetable," pp. 238-239.

${ }^{260}$ Johannes Schlageter, "Die Entwicklung der Kirchenkritik des Petrus Johannis Olivi von der 'Quaestio de altissima paupertate' bis zur 'Lectura super apocalypsim,"' Wissenschaft und Weisheit. Zeitschrift für Augustinisch-Franziskanische Theologie und Philosophie in der Gegenwart 47 (1984), 100-131, 105 and note 17.

${ }^{261}$ Burr, “Olivi’s Apocalyptic Timetable,", p. 239.

${ }^{262}$ As observed by Manselli, "Il tempo escatologico (secoli xii-xiii)," p. 552; reprinted in Idem, Da Gioacchino da Fiore a Cristoforo Colombo, p. 692.

${ }^{263}$ Burr, "Olivi's Apocalyptic Timetable," p. 240.

${ }^{264}$ This idea was fully developed in Raoul Manselli, "Il problema del doppio anticristo in Gioacchino" (see note 29 above).
} 
For Olivi it is detachment from the world while still living in the world. It will prepare for the final judgement after death and for the coming of the last kingdom of God. Men [and women] must be prepared for both, just as individually and collectively they must be ready to resist the temptations of both the mystic and the last Antichrist.

Olivi's impact on the Spirituals was profound and is particularly well illustrated in the writings of Ubertino da Casale (Monferrato, North-West Italy) (1259-c.1328), author of the Arbor vitae crucifixae Iesu, written in seven months while in enforced retreat at La Verna in 1305 and probably revised at Gembloux in 1326-9. ${ }^{265}$ The Arbor is an account of faith and Catholic theology, constructed around the life of Christ. It includes frequent references to his own history and that of the Franciscans and the papacy. Ubertino had encountered Olivi when the latter was lector at the Franciscan studium in Santa Croce in Florence in 1287-9. Like Olivi, Ubertino departed from Joachim in that he attributed not just the second status to Christ but rather the whole of history. ${ }^{266}$ Indeed, he may only have known Joachim's work through that of Olivi, a textually mediated knowledge which was probably increasingly common by this date. ${ }^{267}$ His, like Olivi's, is a Christocentric view based on the experience and role of Francis of Assisi. ${ }^{268}$ But whereas Olivi had, for example, accepted the legitimacy of the resignation of Pope Celestine, Ubertino denied it and unequivocally identified his successor, Pope Boniface VIII, as a mystic Antichrist. ${ }^{269}$ Ubertino also went beyond Olivi in his emphasis on the position of Francis and Dominic. Francis' role was to renew the Church (Book 5, Chaper 6); his rule was a new Gospel because it was the forma evangelice vite, the form of life of Jesus himself and of the apostles. Anyone who claimed that it could not be observed was thereby claiming that the Gospel itself could not be followed. In view of the papal bull Quo Elongati issued in 1230, which had denied any requirement for the Franciscans to observe the whole Gospel as against the provisions of their rule, the import of Ubertino's words was clear. ${ }^{270}$ The persecution of Francis' followers showed how the Church had been taken over by the devil, operating through the mystic Antichrist, through corruption and lies. Boniface VIII was that Antichrist and one of the two monsters of the Apocalypse, whose names were sealed in 666, the number of the Antichrist. The other was his successor, the Dominican Benedict XI (1303-4), who was

\footnotetext{
265 The dates for the revision are proposed by Carlos Mateo Martínez Ruíz, De la dramatización de los acontecimientos de la Pascua a la Cristologia: el cuarto libro del Arbor vitae crucifixae Iesu de Ubertino de Casale (Rome, 2000).

${ }^{266}$ Gian Luca Potestà, Storia ed escatologia in Ubertino da Casale (Milan, 1980), p. 44.

${ }^{267}$ See Gabriele Zaccagnini, "La spiritualità dell' 'Arbor Vitae Crucifixae Iesu' di Ubertino da Casale," in Ubertino da Casale nel VII centenario dell'Arbor Vitae Crucifixae Iesu, 1305-2005. Atti del Convegno di Studi (15 September 2005), ed. Gabriele Zaccagnini (Florence, 2007), pp 37-97, p. 71.

${ }^{268}$ Manselli was the first to point out the distinction between Gioacchino and Olivi on this point. See his, "La terza età, Babylon e l'anticristo mistico (a proposito di Pietro di Giovanni Olivi)," in Bullettino dell'Istituto Storico Italiano per il Medio Evo e Archivio Muratoriano 82 (1970), 47-79, 51, 59; reprinted in Idem, Da Gioacchino da Fiore a Cristoforo Colombo, pp. 155-183, pp. 158-159, 165-166. See also Potestà, Storia ed escatologia in Ubertino da Casale.

${ }^{269}$ See Potestà, Storia ed escatologia in Ubertino da Casale, pp. 86-87.

${ }^{270}$ Bullarium Franciscanum, vol. 1, pp. 68-70.
} 
elected illegitimately because the two Colonna Cardinals, whom Boniface had expelled, had been wrongly excluded from the conclave.

Ubertino had also met John of Parma, at Greccio in July 1285, an encounter which was to act as a catalyst for his later career as a critic of the order. He recalls John as "truly most holy" (vere sanctissimus) and "an angelic man leading an angelic life" (angelicus vir angelicam vitam ducens), a lover of solitude but also an indefatigable preacher. For Ubertino, John was "both a very famous teacher and skilled preacher, and of ... perfection in austerity and humility and charity, the sublimity and solitude of contemplation and flight from all the vanities of the world, gnawn away by complete zeal for God." 271 Ubertino's John was opposed to the relaxation in the order and in the wider Church, a position which he proclaimed publicly before both popes and cardinals. This was why his holiness, although confirmed by miracles, was not recognized by the Church. Ubertino was, moreover, one of the first, along with Bonaventure, to identify Francis with the angel of the sixth seal (something he claimed to have heard from his own mouth), saying

that the sixth seal finds its place in Francis and his status and in the confusion of his life and rule by transgressive sons and bad prelates supporting them, the Church would be consumed by iniquity. ${ }^{272}$

One other contemporary of Ubertino's whose career epitomises the potential impact of eschatological thinking at the end of the 13th century is Arnau de Vilanova (d. 1311), a Catalan Master of Medicine who taught at Montpellier, served in the court of James II of Aragon, treated popes and cardinals, and was a prolific and popular writer of spiritual and medical texts. His prominence helped to spread apocalyptic thinking in Catalonia and southern France. ${ }^{273}$ Like Ubertino, he was possibly influenced by Olivi, who was teaching theology in Montpellier when he was there, though it is not impossible that he worked out his own eschatological program before

\footnotetext{
${ }^{271}$ Arbor Vitae 5.3422.

${ }^{272}$ Arbor Vitae 5.3 422b. On Bonaventure's much debated Joachism, see Joseph Ratzinger, Die Geschichtstheologie des heiligen Bonaventura (Munich-Zurich, 1959), esp. pp. 83-85, 106-111, 119-120; published in English as The Theology of History in St. Bonaventure (Chicago, 1971); Stephan Otto, "Bonaventuras christologischer Einwand gegen die Geschichtslehre des Joachim von Fiore," in Die Mächte des Guten und Bösen. Vorstellungen im XII. und XIII. Jahrbundert über ihr Wirken in der Heilsgeschichte, ed. Albert Zimmermann (Miscellanea mediaevalia, 11) (Berlin-New York, 1977), pp. 113-130; E. Randolph Daniel, “St. Bonaventure's Debt to Joachim," Medievalia et Humanistica, n.s. 11 (1982), 61-75; Paolo Vian, "Bonaventura da Bagnoregio di fronte a Gioacchino da Fiore e al gioacchinismo," Antonianum 65 (1990), 133-160; Ilia Delio, "From Prophecy to Mysticism: Bonaventure's Eschatology in Light of Joachim of Fiore," Traditio 52 (1997), 153-177; Jan Van den Eijnden, "Bonaventura und das Gedankengut des Joachim von Fiore. Der Einfluß des franziskanischen Kontexts auf eine theologische Diskussion," Collectanea Franciscana 71 (2001), 65-85; Paul Zahner, Die Fülle des Heils in der Endlichkeit der Geschichte. Bonaventuras Theologie als Antwort auf die franziskanischen Joachiten (Franziskanische Forschungen 41) (Werl, 1999).

${ }^{273}$ See Gian Luca Potestà, "Radical Apocalyptic Movements in the Late Middle Ages," in The Continuum History of Apocalypticism, eds. Bernard McGinn, John J. Collins, and Stephen J. Stein (New York, 2003), pp. 299-322, p. 303.
} 
Olivi. ${ }^{274}$ Like Joachim, he considered himself to have had a revelatory experience which allowed him to understand scripture. ${ }^{275}$ Unlike either man, he was never a churchman, making his claims to spiritual illumination particularly challenging to the clergy. He seems to have read all of Joachim's writings, or at least his principal works, perhaps while a student at the Dominican school in Barcelona, and his own early works include an introduction to the de Semine Scripturarum, an apocalyptic text that he believed to be by Joachim. ${ }^{276} \mathrm{He}$ adopted many aspects of Joachim's exegetical techniques, including his use of concords to explain events related to the Last Times and, probably, the concept of three status. ${ }^{277}$ In his Tractatus de tempore adventus Antichriste and De mystero cymbalorum, completed in the 1290s, he dated the beginning of the reign of Antichrist to the 1360s or 1370s. ${ }^{278}$ At first he avoided widespread circulation of his thought, but when diplomatic business on behalf of James of Aragon took him to Paris he approached some of the Masters of Theology there, hoping for approval. Instead, following pressure from these same theologians, the Bishop of Paris and other University officials, he was arrested, put on trial in the autumn of 1300, and forced to withdraw a summary of passages from his work, which was burned. ${ }^{279}$ His time in prison was brief, perhaps because of assistance from the French royal house. ${ }^{280}$ Once freed, he disavowed his recantation and in October appealed to the pope. This led to a second trial in the spring of 1301 in the papal consistory, which, inevitably, reached the same conclusion as the Parisian Masters. Arnau was however protected by Boniface VIII, whom he treated for kidney stones and who, according to a Catalan envoy at the papal court, for this reason called him

\footnotetext{
${ }^{274}$ As argued by Robert Lerner, "The Medieval Return to the Thousand Year Sabbath," in The Apocalypse in the Middle Ages, eds. Richard K. Emmerson and Bernard McGinn (Ithaca, NY, 1993), pp. 51-71, p. 63. See also Joseph Ziegler, Medicine and Religion c.1300: the Case of Arnau de Vilanova (Oxford, 1998), p. 52.

${ }^{275}$ Lerner "Ecstatic Dissent," p. 44-46 notes that he claimed divine revelation after his affairs became desperate.

${ }^{276}$ The dating and attributions of Arnau's works remain contested. See Josep Pararnau i Espelt, "L'autor d'un tractat Alquímic podia trobar en l'obra autèntica d'Arnau de Vilanova alguna raó per a atribuir-lo a ell?" in Actes de la "II Trobada Internacional d'Estudis sobre Arnau de Vilanova," ed. Josep Perarnau (Barcelona, 2005), pp. 151-198; and the edition of the Introductio, ibid., pp. 199-216.

${ }^{277}$ Harold Lee, "Scrutamini Scripturas: Joachimist Themes and Figurae in the Early Religious Writing of Arnold of Vilanova," Journal of the Warburg and Courtauld Institutes 37 (1974), 33-56, 33, 52.

278 "De tempore adventus Antichristi," ed. Josep Perarnau i Espelt, in "El text primitiu del De mysterio cymbalorum ecclesiae d'Arnau de Vilanova," Arxiu de textos catalans antics 7/8 (1988-89), 7-169.

${ }^{279}$ Clifford R. Backman, "The Reception of Arnau de Vilanova's Religious Ideas," Christendom and Its Discontents, ed. Scott L. Waugh and Peter Diehl (Cambridge, 1996), pp. 112-131. Some of the difficulties such prophetic ideas presented for the Paris theologians are discussed in Ian P. Wei, "Predicting the Future to Judge the Present: Paris Theologians and Attitudes to the Future," in Medieval Futures: Attitudes to the Future in the Middle Ages, eds. John A. Burrow and Ian P. Wei (Woodbridge, 2000), pp. 19-36, with particular reference, pp. 34-35, to a quodlibetal discussion held in 1300 by Peter of Auvergne about whether the Antichrist was to come soon, which he used to attack Arnau. On the hostility to prophecy from university theologians, who claimed a papally supported monopoly on scriptural teaching and interpretation, see André Vauchez, "Les théologiens face aux prophéties à l'époque des papes d'Avignon e du Grand Schisme," Mélanges de l'École française de Rome. Moyen âgeTemps Modernes 102 (1990), 577-588, 578.

${ }^{280}$ As suggested by Ziegler, Medicine and Religion, p. 27.
} 
"the greatest cleric in the world." ${ }^{281}$ A further treatise on the Antichrist presented to Boniface in 1302, Philosophia catholica et divina, which was apparently influenced by developing ties to Occitan spiritual Franciscans, moved from prophecy of the future to emphasis on the urgent need to reform the Church. He was to face trial again--most notably in Perugia in 1304 when he went to the pope to defend himself against the attacks of the Dominicans, his former teachers--but later enjoyed the support of Pope Clement V and King James II of Aragon, whose royal house he considered to be the most likely source of the divinely-appointed king who would purge Christendom. ${ }^{282}$ In 1305-6 he wrote an Expositio super Apocalypsi which makes clear that, although he did not follow all the Calabrian's plan, he accepted Joachim's interpretation of the vision of seven churches as that of the history of the Church, with his own time that of preparation for Antichrist, when a chosen few "would 'penetrate most deeply' into the secrets of Scripture." 283 In 1306 he also wrote a Responsio ad Cavillationes, a pointby-point defence of his earlier Tractatus de tempore and in 1308, following a meeting with Greek monks, he translated several of his key works into Greek. ${ }^{284}$ In his later works Arnau adopted the concept of a pastor angelicus, an angelic pope who would support reform along the lines of the primitive Church. This pope would succeed Clement V.

Arnau was always polemical and although he died a free man, his spiritual writings were carefully re-examined and posthumously condemned at the Council of Tarragona in $1316 .{ }^{285}$ Nonetheless, they were to be read by figures such as the Franciscan alchemist, Jean de Roquetaillade/Rupescissa (c.1310-c.1362) who was imprisoned for a long period because of his apocalyptic views. Jean claimed, using alchemical metaphors, that enduring the hardships of prison qualified him to write his Visiones seu revelationes (1349), Liber ostensor quod adesse festinant tempora, and a Vademecum in tribulatione (1356), which amounted to a compendium of his apocalyptic views and made use of both Arnau and Joachim. ${ }^{286}$

Arnau's writings also introduce another thread in the reception of Joachim's works, that of Jewish exegesis. He had studied Hebrew writings as a student in the Dominican language school in Barcelona and argued, like Joachim and his own Dominican masters, that only Christians, enlighted by the Gospel, could truly understand Jewish scriptures, since the Jews themselves lacked such enlightenment (among other things, he proposed that the lack of vowels in Hebrew indicated their limited illumination). ${ }^{287}$ Arnau's own work was influenced by Jewish doctrines concerning the coming of the Antichrist and in particular by the prophetic Kabbalism

${ }^{281}$ Cited in Backman, “The Reception of Arnau de Vilanova's Religious Ideas," p. 115.

${ }^{282}$ Ziegler, Medicine and Religion, pp. 27, 32.

${ }^{283}$ Arnaldus de Vilanova, Expositio super Apocalypsi, ed. J. Carreras i Artau with Olga Marinelli

Marcacci and Josepho M. Morató i Thomàs (Corpus Philosophorum Medii Aevi: Arnaldi de Vilanova

Scripta Spiritualia, 1) (Barcelona, 1971). Also cited in Lerner, "Ecstatic Dissent," p. 51.

${ }^{284}$ Backman, "The Reception of Arnau de Vilanova's Religious Ideas," p. 114.

${ }^{285}$ Ziegler, Medicine and Religion, pp. 32-33.

${ }^{286}$ See Jeanne Bignami-Odier, Études sur Jean de Roquetillade (Johannes de Rupescissa) (Paris, 1952); and Leah DeVun, Prophecy, Alchemy, and the End of Time: John of Rupescissa in the Late Middle Ages (New York, 2009).

${ }^{287}$ Lee, “Scrutamini Scripturas: Joachimist Themes," p. 49. 
of Abraham Abulafia (c.1240-1291) ${ }^{288}$ Active in southern Italy and Sicily, Abulafia had argued that the end of the world was approaching and that he himself was chosen to reveal divine truth as a self-proclaimed Messiah. ${ }^{289}$ Arnau certainly seems to have been influenced by Kabbalist exegesis, but Harold Lee argues convincingly that this was not a guiding inspiration. His concern was, like Joachim and his teachers, to elucidate scripture so as to understand God's plan for the world. By contrast, the objective of the Kabbalist tradition was mystical experience of union with God. Arnau made eclectic use of Jewish texts and techniques, but his own apocalyptic vision was more fundamentally shaped by Joachimist traditions. ${ }^{290}$

The impact of Joachism on churchmen at the end of the 13th century was by no means restricted to the three figures discussed here. An anonymous Oracle of the Angel Cyril (Oraculum angelicum Cirilli) describes a conflict between a holy pope to come, or orthopontifex, and an evil pseudopontifex. It was allegedly presented to a Carmelite friar who asked Joachim to explain it, but seems to reflect the Spirituals' view of Celestine and Boniface. Dominicans too engaged in the discussions of good and bad popes, men such as the preacher and mystic, Robert d'Uzès (1263-1296), of whom Jean de Roquetuillade later wrote that he was one of the brethren who "truly had the spirit of prophecy" (spiritum prophecie veraciter habuerunt). Robert wrote in his Visions of a coming reparator or saviour dressed, remarkably, in the sackcloth of the Franciscans. ${ }^{291} \mathrm{He}$ also described a good pope, Celestine, "angel of the Church" and a bad pope, Boniface, its "idol." 292

Finally, the end of the 13th century also saw the appearance of the popular and naturally enigmatic prophecies generally known as the Latin pope prophecies (Vaticinia pontificum or de summis pontificis), a long-used designation which in fact encompasses three separate works: the earliest, which Lerner calls the Genus nequam group on the basis of its incipit, is a collection of short texts part of which was probably circulating as early as $1287 .{ }^{293}$ With far-fetched, captioned illustrations assigning prophecies to future popes, they were attributed by contemporaries to Joachim, though modern research has more appropriately tied the origins to

\footnotetext{
${ }^{288}$ J. Carreras y Artau, “Arnau de Vilanova y las Culturas Orientales," Homenaje a Millás-Vallicrosa, 2 vols. (Barcelona, 1954-6), vol. 1, pp. 309-321, pp. 314-316. See also Lee, "Scrutamini Scripturas: Joachimist Themes," pp. 53-54.

${ }^{289}$ See Harvey J. Hames, Like Angels on Jacob's Ladder: Abrabam Abulafia, the Franciscans, and Joachimism (Albany, NY, 2007), who argues that Abulafia adapted Joachim's work to the Kabbalist tradition. This contrasts with the earlier approach of Lee, who followed Gershom Scholem in arguing that the two traditions developed independently. Lee, "Scrutamini Scripturas: Joachimist Themes," p. 55 .

${ }^{290}$ Lee, "Scrutamini Scripturas: Joachimist Themes," p. 54.

${ }^{291}$ Cited by Paul Amargier, "Jean de Roquetaillade et Robert d'Uzès," Mélanges de l'Ecole française de Rome. Moyen-Age-Temps Modernes 102 (1990), 305-310, 306. See also Idem, "Robert d'Uzès, prédicateur: La pastorale mendiante," Cabiers de Fanjeaux 32 (1997), 159-170.

${ }^{292}$ McGinn, "Angel Pope and Papal Antichrist," p. 164.

${ }^{293}$ Samantha Kelly, "The Visio Fratris Johannis: Prophecy and Politics in Late-Thirteenth-Century Italy," Florensia, 8-9 (1994-1995), 7-42. See also The Late Medieval Pope Prophecies. The Genus Nequam Group, ed. Martha H. Fleming (Medieval \& Renaissance texts \& studies 204), (Tempe, Arizona, 1999), p. 6 and earlier bibliography ibid.
} 
Byzantine, so-called "Leo-prophecies" about future emperors. ${ }^{294}$ Enormously popular and widely copied, the earliest drafts appear to have referred to Cardinals, not popes, but later versions covered the pontiffs from Nicholas III (1277-1280) to either Boniface VIII or Benedict XI (1303-1304) before inserting a future angelic pope. ${ }^{295}$ They usually include five saintly popes portrayed in the company of angels, a vision also picked up in the near-contemporary Liber de Flore, which combined the idea of angelic popes and messianic rulers to propose that the first of the angelic popes would be aided by a French king who would become emperor, retake Jerusalem and retire as a Franciscan. ${ }^{296}$ It was texts such as these, rather than the works of Olivi or Ubertino, which probably did most to propagate the belief in an angelic pope and to maintain Joachim's fama into the new century.

$* * *$

As the travails of Olivi and Arnau underscore, not everyone was convinced by Joachim or pseudo-Joachim. There were plenty of doubters, both those who rejected apocalyptic fervour altogether and those who accepted such eschatological logic but expressed doubts about contemporary post eventum prophecies assigned to Joachim. At the end of the century, Boniface VIII is supposed to have asked "Why are these fools awaiting the end of the world?" (Cur fatui exspectant finem mundi?), expressing a frustration similar to that of David of Augsburg decades earlier. ${ }^{297}$ Neither man was unusual. ${ }^{298}$ Salimbene reports a lengthy debate between a disbelieving Dominican, Pietro di Puglia and Hugh of Digne. ${ }^{299}$ Scepticism about specific prophetic texts is typified by the English Benedictine Matthew Paris, who pointed out that the

\footnotetext{
${ }^{294}$ See Lerner, "On the Origins of the Earliest Latin Pope Prophecies," pp. 611-635 and Late Medieval Pope Prophecies. The Genus Nequam Group, ed. Fleming pp. 3-5. A facscimile of a Vatican manuscript copy produced c. 1500 is in Weissagungen über die Päpste. Vat. Ross. 374, with an introduction by Robert Lerner and Robert Moynihan (Zurich, 1985).

${ }^{295}$ The nature and relationship of the three versions (the other two dating from the 1320s) is summarized in The Late Medieval Pope Prophecies. The Genus Nequam Group, ed. Fleming, pp. 6-7. See also Andreas Rehberg, "Der 'Kardinalsorakel'-Kommentar in der 'Colonna'-Handschrift Vat. lat. 3819 und die Entstehungsumstände der Papstvatizinien," Florensia 5 (1991), 45-112, at 50-58; Helene Millet and Dominique Rigaux, "Aux origines du succès des Vaticinia de summis pontificibus," in Fin du monde et signes des temps: visionnaires et prophètes en France méridionale (fin XIII-début XIV siècle) (Cahiers de Fanjeaux, 27) (Toulouse, 1992), 129-156. See now also Hélène Millet, Il libro delle immagini dei papi. Storia di un testo profetico medievale (La corte dei papi, 9) (Rome, 2002).

${ }^{296}$ Herbert Grundmann, "Die Liber de Flore," Historisches Jabrbuch 49 (1929), 33-91. See also Reeves, The Influence of Prophecy, pp. 320-321, 403-406 and McGinn, "Angel Pope and Papal Antichrist," 165. Late Medieval Pope Prophecies. The Genus Nequam Group, ed. Fleming p. 3.

${ }^{297}$ Quoted in Bernard McGinn, "The Abbot and the Doctors: Scholastic Reactions to the Radical Eschatology of Joachim of Fiore," in Church History 40 (1971), 30-47, 30.

${ }^{298}$ See Vauchez, "Les theologiens face aux propheties," p. 579; "Lo statuto della profezia nel medioevo," eds. Gian Luca Potestà and Roberto Rusconi, Cristianesimo nella storia 17/2 (1996), esp. pp. 243-250; and Jean-Pierre Torrell, Recherches sur la theorie de la prophetie au moyen age. xiie-xive siècles: Etudes et textes (Dokimion, 13) (Fribourg, 1992).

${ }^{299}$ Salimbene, Cronica, ed. Scalia, pp. 361-383. See also above note 114. Pietro may be introduced so as to allow Hugh of Digne to convince him of the truth of Joachim's message, but he nonetheless voices the sort of arguments sceptics were likely to propose.
} 
Evangelium Aeternum which circulated as Joachim's could not be any such thing since it discussed events in Frederick's life after the abbot's death. ${ }^{300}$ Thomas Aquinas both noted that many opinions attributed to Joachim were in reality those of unscrupulous followers, and censured his prophesying. ${ }^{301}$ His views were in line with those of many university theologians and were adopted in the Annales and the Historia Ecclesiastica of his friend, the Dominican Ptolemy of Lucca (d.1327), who condemned Joachim's prophesying and underlined the link between Joachim and Gerardo da Borgo San Donnino, an "evil sect" which took its origin from the words of Joachim and his book ("quae quidem secta pessima originem traxit ex verbis Joachin [sic], et libris ejus ...”). ${ }^{302}$

Ptolemy was not alone in his criticism. The Carmelite theologian and inquisitor Guiu Terreni. who was employed by Pope John XXII (1316-34) to counter the arguments of the Spiritual Franciscans, saw Joachim as the root of the problem. Although he had probably not himself read Joachim's works, he included him in his Summa de haeresibus et earum confutationibus, a compendium of contemporary heresies and how to refute them. Joachim's ideas also continued to circulate in the company of numerous pseudo-Joachim works. One manuscript, now in London, a collection of excerpts from both Joachim and pseudo-Joachim, together with the Protocol of Anagni, was once owned by Richard Kilvington, Dean of St Paul's (135361) and a friend of the great critic of the mendicants, Richard Fitzralph, Archbishop of Armagh. ${ }^{303}$ The same collection is also extant in a manuscript which once belonged to the theologian Peter of Limoges. ${ }^{304}$ Joachite overtones may be traced in the careers of Beguines adjudged heterodox such as $\mathrm{Na}$ Prous Boneta, a Beguine whose deposition before the inquisition in 1325 identifies her as the herald of the Holy Spirit and shows Olivi's influence. ${ }^{305}$ But perhaps most famously, the 14th century also saw Joachim's name given new literary fame in the poetry of Dante, who placed him in paradise in the Divina Commedia:

...e lucemi dallato,

Il calavrese abate Giovacchino

di spirito profetico dotato. ${ }^{306}$

Joachim the prophet of Antichrist was thus soon to be discussed in the new genre of commentaries on Dante's poem. ${ }^{307}$

\footnotetext{
${ }^{300}$ Paris, Chronica majora, ed. Luard, vol. 6, p. 339.

${ }^{301}$ On Aquinas see the chapter by Sven Grosse in this volume.

302 Tholomeus von Lucca, Historia Ecclesiastica Nova 22:13, ed. Ottavio Clavuot after preparations by Ludwig Schmugge, MGH SS, 39 (Hanover, 2009), p. 557 (and ibid., pp. 499 and 513).

${ }^{303}$ London, British Library, MS Royal 8 F XVI.

${ }^{304}$ Paris, BnF lat. 16397. See Kathryn Kerby-Fulton, Books under Suspicion: Censorship and Tolerance of Revelatory Writing in Late Medieval England (Notre Dame, Ind., 2006) and a forthcoming article by her (to be published in a volume in memory of Marjorie Reeves); and Nicole Bériou, "Pierre de Limoges et la fin des temps," Mélanges de l'Ecole Française de Rome, Moyen Age-Temps Modernes 98/1 (1986), 65-107.

${ }^{305}$ David Burr, "Na Prous Boneta and Olivi," Collectanea franciscana 67 (1997), 477-500.

306 The Divine Comedy, Paradiso 12.139-141. The bibliography on Dante and Joachim is vast, but see most recently Dante and his Literary Precursors. Twelve Essays, eds. John C. Barnes and Jennifer Petrie (Dublin 2007).
} 


\section{Conclusions: How Influential was Joachim?}

As Bernard McGinn wrote in an essay on the impact of Joachim of Fiore in the 14th and 15th centuries, "it is always difficult to know whether to claim too much or too little for Joachim of Fiore's influence." 308 The task is no less problematic for the hundred years immediately following Joachim's death in 1202, despite the fundamental work of Reeves, McGinn himself, and the numerous other scholars whose efforts underlie this or any new assessment. It would not be easy to prove that anyone ever acted directly as a result of one of the abbot's prophecies. But prophecy and eschatology were important tools for 13th-century polemicists. While the intended audience for a specific text is not always evident, it is clear that Joachim's ideas had a powerful impact on the imagination of innumerable 13th-century writers. As Potestà argues, his writing served to update the lexicology of eschatology, giving it a new lease of life. ${ }^{309}$ It certainly fell on fertile territory. The crises of the late 12 th and 13th centuries leant themselves to prophetic interpretation of the sort Joachim provided. The confidence about the future available through the prophecies was undoubtedly attractive. And this was not restricted to political concerns: the prophecies provided information about the world after death. Their wide circulation and updating undoubtedly reflects a keen interest in the history of salvation.

Previous writers attempting to summarize the impact of Joachim have adopted a variety of approaches. Reeves read contemporary and later writers looking for the most noteworthy signs of his historical structures, the patterns of twos, threes, and sevens, and for knowledge of the figurae. She found him ever more frequently cited. Together with Bloomfield she concluded that in the first half of the 13th-century Joachim was principally known as a prophet of the Antichrist. ${ }^{310}$ Only after the crisis provoked by Gerardo da Borgo San Donnino in 1254-5 did he become known for his ideas about a better earthly future. ${ }^{311}$ Others (including the Jesuit Henri de Lubac), sought to divide the reception history into two, separating historical Bible exegesis in the style of Alexander Minorita from the work of theologians who used his idea of a third earthly status as the basis for their own. ${ }^{312}$

In this chapter I have instead sought to focus on the mechanisms for the transmission of his thinking and to exemplify the ways in which it was deployed. I have avoided asserting patterns which might imply a simple tradition, in part because the dating of so many works has either been recently revisited or remains open to revision. But for readers keen to have a convenient summary, the chronology of his influence can perhaps appropriately be divided into three phases. The first is the remarkable evidence for his fama as a prophet spreading as far afield as England, the

\footnotetext{
${ }^{307}$ Including by Pietro Alighieri and Benvenuto da Imola. These are now conveniently available through the Dartmouth Dante Project website http://dante.dartmouth.edu.

${ }^{308}$ Bernard McGinn, "Influence and Importance in Evaluating Joachim of Fiore," p. 15 (see note 6 above).

${ }^{309}$ Potestà, “Gli spazi dell’Anticristo,” p. 420.

${ }^{310}$ Bloomfield and Reeves, “The Penetration of Joachism into Northern Europe,” p. 792.

${ }^{311}$ Lerner, "Refreshment of the Saints," p.120.

${ }^{312}$ Henri du Lubac, La posterité spirituelle de Joachim de Flore, vol. 1, 49-67 (as note 14).
} 
German Empire, Navarre, central and northern Italy and northern France already by the second decade of 1200 s. This was followed by the emphatic engagement of prominent mendicants and the political instrumentalisation in mid-century of both Joachite and pseudo-Joachite ideas by the papal and imperial courts and, spectacularly, by Friar Gerardo of Borgo San Donnino and Master William of Saint-Amour. Finally, after mid century, came the better documented and perhaps still more inventive response to his works by theologians and apologists such as Olivi, Arnau de Vilanova and the Spiritual Franciscans (as well, of course, as critics such as Aquinas). As the century progressed responses to his work focussed more on the dissident undertones, with their criticism of the worldly Church, as an emphasis on apocalyptic thought increasingly attracted accusations of heresy.

An alternative approach might be to observe that down to c.1240 Joachim's ideas tended to circulate most often in his own works (or slightly revised redactions), but from the 1240s onwards, the emergence on a substantial scale of pseudo-Joachite texts gave his reputation, if not his direct influence, a new impulse. ${ }^{313}$ Establishing more exact parameters for this influence remains problematic because, as with any hermetic tradition, it was easily subject to re-interpretation. Texts were not stable: the "true" nature of Joachim's spiritual men could be reconfigured, as could the identity of the Antichrist, whether emperor, king, or pope. Joachim's fama meant that whether or not a writer chose to reiterate his ideas, his name might usefully be deployed to confer authenticity. The accumulation of criticisms and associations with heresy did little to limit this trend in the century down to $c .1300$.

\footnotetext{
${ }^{313}$ Wannenmacher, 'Apocalypse, Antichrists and the Third Age', reminds us, p. 268, that [by the end of the thirteenth century] neither his fiercest critics nor his keenest supporters 'had [ever] read a single word of what Joachim of Fiore had actually written, but were dependent exclusively on PseudoJoachim's writings'.
} 